\begin{tabular}{|l|c|c|c|r|}
\hline $\begin{array}{l}\text { Cuadernos de Investigación Geográfica } \\
\text { Geographical Research Letters }\end{array}$ & 2017 & N $^{\circ} 43(2)$ & pp. 377-428 & $\begin{array}{r}\text { ISSN 0211-6820 } \\
\text { eISSN 1697-9540 }\end{array}$ \\
\hline
\end{tabular}

\title{
DEGLACIATION OF THE LAURENTIDE ICE SHEET FROM THE LAST GLACIAL MAXIMUM
}

\author{
C.R.STOKES*
}

Department of Geography, Durham University, Durham, DH1 3LE, UK

\begin{abstract}
The last deglaciation of the Laurentide Ice Sheet (LIS) was associated with major reorganisations in the ocean-climate system and its retreat also represents a valuable analogue for understanding the rates and mechanisms of ice sheet collapse. This paper reviews the characteristics of the LIS at its Last Glacial Maximum (LGM) and its subsequent deglaciation, with particular emphasis on the pattern and timing of ice margin recession and the driving mechanisms of retreat. The LIS initiated over the eastern Canadian Arctic 116-110 ka (MIS $5 d)$, but its growth towards the LGM was highly non-linear and punctuated by several episodes of expansion ( 65 ka: MIS 4) and retreat ( 50-40 ka: MIS 3). It attained its maximum position around 26-25 ka (MIS 2) and existed for several thousand years as an extensive ice sheet with major domes over Keewatin, Foxe Basin and northern Quebec/Labrador. It extended to the edge of the continental shelf at its marine margins and likely stored a sea-level equivalent of around $50 \mathrm{~m}$ and with a maximum ice surface $\sim 3000 \mathrm{~m}$ above present sea-level. Retreat from its maximum was triggered by an increase in boreal summer insolation, but areal shrinkage was initially slow and the net surface mass balance was positive, indicating that ice streams likely played an important role in reducing the ice sheet volume, if not its extent, via calving at marine margins. Between $\sim 16$ and $\sim 13 \mathrm{ka}$, the ice sheet margin retreated more rapidly, particularly in the south and west, whereas the north and east underwent only minimal recession. The overall rate of retreat decreased during the Younger Dryas (YD), when several localised readvances occurred. Following the $Y D$, the ice sheet retreated two to five times faster than previously, and this was primarily driven by enhanced surface melting while ice streams reduced in effectiveness. Final deglaciation of the Keewatin and Foxe Domes, left a remnant Labrador Dome that disappeared $\sim 6.7 \mathrm{ka}$.
\end{abstract}

\section{La deglaciación del inlandsis Lauréntide desde el Último Máximo Glaciar}

RESUMEN. La última deglaciación del inlandsis Lauréntide (LIS) estuvo relacionada con grandes reorganizaciones en el océano-clima y su retroceso representa un valioso ejemplo para comprender las tasas y mecanismos del colapso del inlandsis. Este artículo revisa las características del LIS en su Último Máximo Glaciar (LGM) y su consiguiente deglaciación, con especial énfasis en 
el patrón y temporalidad de la recesión del margen de hielo y de los factores de retroceso. El LIS se inició en el este del Ártico canadiense hace $116-110 \mathrm{ka}$ (MIS $5 d$ ), aunque su crecimiento hacia el LGM no fue lineal sino afectado por distintos episodios de expansión ( 65 ka: MIS 4) y retroceso ( 50-40: MIS 3). Alcanzó su máxima posición alrededor de 26-25 ka (MIS 2) y existió durante varios miles de años como un extenso inlandsis con importantes domos en Keewatin, Foxe Basin y norte de Quebec/Labrador. Se extendió hasta el límite de la plataforma continental en sus márgenes marinos y probablemente almacenó el equivalente de unos $50 \mathrm{~m}$ de nivel del mar, con una máxima acumulación de hielo de $3000 \mathrm{~m}$ sobre el actual nivel del mar. El retroceso desde su máximo fue desencadenado por un aumento en la insolación del verano boreal, aunque la contracción fue inicialmente lenta y el balance neto de masa superficial fue positivo, indicando que los ríos de hielo jugaron un papel importante en la reducción del volumen del inlandsis, si no en su extensión, por medio de fusión en los márgenes marinos. Entre $\sim 16$ y $\sim 13 \mathrm{ka}$, el borde del inlandsis retrocedió más rápidamente, sobre todo en el sur y oeste, mientras el norte y el este experimentaron una recesión mínima. La tasa general de retroceso disminuyó durante el Younger Dryas (YD), cuando ocurrieron algunos avances locales. Después del YD, el inlandsis retrocedió a un ritmo dos veces superior al anterior, y se debió especialmente a un incremento de la fusión superficial, mientras los ríos de hielo redujeron su eficacia. La deglaciación final de los domos de Keewatin y Foxe dejó un único domo en Labrador que desapareció hacia $6.7 \mathrm{ka}$.

Key words: Laurentide Ice Sheet, Last Glacial Maximum, deglaciation, ice streams.

Palabras clave: Inlandsis Lauréntide, Último Máximo Glaciar, deglaciación, ríos de hielo.

Received: 6 February 2017

Accepted: 1 March 2017

* Corresponding author: Chris R. Stokes, Department of Geography, Durham University, Durham, DH1 3LE, UK. E-mail address: c.r.stokes@durham.ac.uk

\section{Introduction}

The North American Laurentide Ice Sheet (LIS) was the largest ice sheet to grow and decay during the last glacial cycle, dominating Late Pleistocene fluctuations in global sea-level (Lambeck et al., 2014) and delivering the largest contribution to early Holocene sea level rise (Tarasov et al., 2012; Peltier, 2004). Accurate reconstructions of its extent, volume and dynamics are, therefore, critical to our understanding of glacialinterglacial cycles and the sensitivity of ice sheets to climate change (Clark et al., 2009; Carlson and Clark, 2012). Knowledge of its deglaciation is also required to understand the rates, magnitude and mechanisms of ice sheet decay and associated impacts on sea level (Carlson et al., 2008; Carlson and Winsor, 2012; Kleman and Applegate, 2013; Stokes 
et al., 2016), which is relevant to assessments of the future stability of modern-day ice sheets in Greenland and Antarctica (IPCC, 2013; Nick et al., 2013; Ritz et al., 2015). It is also clear that, in addition to responding to climate forcing, the behaviour of the LIS was capable of driving abrupt climate change through the delivery of both meltwater and icebergs that perturbed the ocean-climate system (Barber et al., 1999; Clark et al., 2001). More broadly, the configuration and retreat history of the LIS was an important constraint on the migration and dispersal of flora and fauna (Shapiro et al., 2004), including early humans (Goebel et al., 2008; Eriksson et al., 2012; Dixon, 2013; Pedersen et al., 2016).

Given its size and importance, the LIS is one of the most widely-studied palaeoice sheets and there are hundreds of papers that have attempted to reconstruct its extent and dynamics using a variety of both empirical and modelling approaches (see review in Stokes et al., 2015). However, the majority of studies, especially those taking an empirical approach, have tended to focus on specific regions and time periods, and fewer studies have attempted to summarise both the timing and driving mechanisms of deglaciation since the global Last Glacial Maximum (gLGM). Building on several major syntheses over the last few decades (Denton and Hughes, 1981; Dyke and Prest, 1987; Fulton, 1989; Dyke, 2004), this paper aims to provide an up-to-date review of the LIS at the gLGM with an emphasis on the pattern and timing of its deglaciation and the mechanisms that led to its demise. Following an overview of the characteristics of the LIS at its Local LGM (LLGM) in Section 2, Section 3 focusses on the pattern and timing of deglaciation, followed by a discussion of the mechanisms that have been invoked to explain deglaciation in Section 4. Some of the associated impacts of deglaciation, such as the origin of Heinrich events (e.g. Andrews, 1998) and major meltwater pulses and routing (e.g. Tarasov et al., 2012; Gregoire et al., 2012) are beyond the scope of the present paper and will receive less attention (see comprehensive reviews by Hemming, 2004; Carlson and Clark, 2012).

For the purposes of this paper, I use 'Laurentide Ice Sheet' in its broadest sense and, except where indicated explicitly. I include the Innuitian Ice Sheet (IIS) (Dyke et al., 2002) and other small ice caps (e.g. in Newfoundland and the Appalachians) with which it was contiguous for most of its history. This does not include the Cordilleran Ice Sheet (CIS), which was a separate ice sheet except for brief periods during glacial maxima (Prest, 1969; Dyke and Prest, 1987; Dyke et al., 2002; Stokes et al., 2012). For consistency, all dates are quoted in thousands of calendar years (ka) before present. Where the original source used only radiocarbon ages (e.g. Dyke and Prest, 1987), they have been converted to calendar years using a mixed marine and Northern Hemisphere atmosphere calibration curve (Stuiver et al., 2017) and the original radiocarbon dates appear in parentheses $\left({ }^{14} \mathrm{C} \mathrm{ka}\right)$.

\section{The Laurentide Ice Sheet at its Last Glacial Maximum}

\subsection{Inception and build-up to its Last Glacial Maximum}

Before describing the characteristics of the LIS at its LGM, it is useful to briefly outline its inception and growth since the last interglacial during Marine Isotope Stage 5 (MIS 5). Unfortunately, this aspect of the ice sheet's history is very poorly constrained compared to 
the post-LGM period, largely because of the fragmentary nature of the terrestrial evidence relating to ice sheet build-up, most of which was erased by the much larger Late Wisconsinan (MIS 2) ice sheet. This has perhaps led to an over-reliance on numerical ice sheet models of pre-LGM ice sheet configurations (e.g. Marshall et al., 2000; Kleman et al., 2002; Stokes et al., 2012) which are themselves limited by the availability of constraint data. However, the ocean-sediment record has proved particularly useful for investigating pre-LGM iceberg fluxes and meltwater events (e.g. Andrews and MacLean, 2003; Hemming, 2004), and there are pockets of evidence in the glacial geomorphological and stratigraphic record (e.g. Kleman et al., 2010) that have survived modification and, in some places, been dated to periods prior to the LGM (e.g. Allard et al., 2012; Dalton et al., 2016).

During the penultimate glacial maximum around $140 \mathrm{ka}$ (MIS 6), the LIS is known to have been smaller than its LGM (MIS 2) counterpart, and is thought to have been similar in size to its extent around $13 \mathrm{ka}$ (Colleoni et al., 2016). This is consistent with global sea level records and empirical evidence that indicates that the Eurasian Ice Sheet was larger during MIS 6 than during MIS 2 (Svendsen et al., 2004). Indeed, the smaller size of the LIS is consistent with changes in large-scale atmospheric circulation that facilitated the development of a larger Eurasian Ice Sheet during MIS 6 (Colleoni et al., 2016). Little is known about the deglaciation of the LIS at the end of MIS 6, but a major glacial lake outburst flood has been reported from a proximal marine core in the Labrador Sea around $124 \mathrm{ka}$ (Nicholl et al., 2012), which may be analogous to the widely reported drainage of glacial Lake Agassiz during the final deglaciation of the LIS around $8.2 \mathrm{ka}$ (e.g. Barber et al., 1999). Following this event, the general consensus is that there was virtually no ice cover in North America during the peak of the MIS 5 (Sangamonian) interglacial ( 125-122 ka), which is primarily based on ages obtained from organic-rich sediments in the Hudson Bay Lowlands (e.g. Allard et al., 2011; Dalton et al., 2016) and a widespread acknowledgement that global sea levels were 6-9 $\mathrm{m}$ higher than present during MIS 5e (e.g. Dutton et al., 2015).

The consensus from both empirically-based arguments and numerical modelling is that the LIS initiated over the Arctic/sub-Arctic plateaux along the eastern seaboard of Canada (e.g. Ives, 1957; Ives et al., 1975; Marshall et al., 2000; Marshall and Clark, 2002; Kleman et al., 2002; Stokes et al., 2012; Abe-Ouchi et al., 2013). These are locations where only a small decrease in temperature resulted in a large decrease in the equilibrium line altitude (ELA) - a process termed 'instantaneous glaciation' (Koerner, 1980). It is thought that an embryonic dome formed over Labrador during MIS 5d (cf. Andrews and Mahaffy, 1976; Boulton et al., 1985; Vincent and Prest, 1987; Clark et al., 1993; Marshall et al., 2000; Kleman et al., 2010), possibly as early as 116-114 ka, and with some modelling (Stokes et al., 2012) indicating a large but thin ice sheet at $110 \mathrm{ka}$ that covered $70-80 \%$ of the area occupied by the MIS 2 ice sheet (see also Vincent and Prest, 1987; Boulton and Clark, 1990a, b; Clark et al., 1993). This "explosive ice sheet growth" (Marshall, 2002: p. 133) during MIS 5d is consistent with records of a rapid fall in global sea level around that time (Marshall et al., 2000; Cutler et al., 2003), but some workers suggest more minimal ice volumes in North America ( 2-3 m of sea level equivalent: Kleman et al., 2002) and that the LIS did not grow substantially until MIS 4 (e.g. Kleman et al., 2002; Marshall and Clark, 2002; Kleman et al., 2010). If the ice sheet was relatively large during MIS 5d (e.g. 
the $\sim 20 \mathrm{~m}$ of sea level equivalent modelled by Stokes et al., 2012), it had shrunk rapidly by $100 \mathrm{ka}$ (MIS 5c) (cf. St-Onge, 1987), and likely existed only as a small, thin ice sheet over the original inception grounds in north-eastern Canada by $80 \mathrm{ka}$ (MIS 5a) (Marshall et al., 2000; Stokes et al., 2012). Thereafter, the LIS is thought to have grown rapidly during MIS 4, reaching a maximum extent around $65 \mathrm{ka}$ (Vincent and Prest, 1987; Marshall et al., 2000; Kleman et al., 2002; Stokes et al., 2012), which coincides with the oldest recognised Heinrich event (H6) and a marked increase in ice-rafted debris from that time (Kirby and Andrews, 1999; Hemming, 2004, Bassis et al., 2017).

Following an MIS 4 maximum that may have been almost as large as the MIS 2 (LGM) volume according to some models (Marshall et al., 2000; Stokes et al., 2012), the ice sheet retreated to a mid-Wisconsinan (early MIS 3) minimum at some point between 60 and $40 \mathrm{ka}$ (Dredge and Thorleifson, 1987; Clark et al., 1993; Kleman et al., 2010; Stokes et al., 2012). Indeed, the extent of the ice sheet during MIS 3 is very poorly constrained (e.g. see review in Dredge and Thorleifson, 1987), with numerical modelling indicating a relatively large ice sheet that stored up to $30 \mathrm{~m}$ of sea level equivalent at $55 \mathrm{ka}$ (Marshall et al., 2000; Stokes et al., 2012), but with a suite of new dates raising the possibility that the Hudson Bay Lowlands, close to the geographic centre of the ice sheet, were completely ice free between $\sim 50$ and $\sim 40 \mathrm{ka}$ (see Dalton et al., 2016). Following the MIS 3 minimum, the ice sheet underwent gradual expansion that was punctuated by episodes of successively less recession (e.g. at $30 \mathrm{ka}$ ) before a final rapid growth towards the maximum LGM position (Dyke et al., 2002; Stokes et al., 2012).

\subsection{The timing of the Local Last Glacial Maximum Laurentide Ice Sheet (Late Wisconsinan)}

In its broadest sense, the global LGM (gLGM) is conventionally defined from sealevel records "as the most recent interval in Earth history when global ice sheets reached their maximum integrated volume" (Clark et al., 2009: p. 710). It has been recognised for some time, however, that because global sea levels are an integrated signal of ice volume, this does not imply that all ice sheets, or even various sectors within the same ice sheet, reached their 'Local' Last Glacial Maximum (from hereon LLGM) extent simultaneously (Clark et al., 2009; Hughes et al., 2013). In a recent synthesis, Clark et al. (2009) constrained the timing of the gLGM period, based on relative sea-level data, as occurring from 26.5 to $19.0 \mathrm{ka}$, and suggested that this broadly coincided with the duration of maximum extent of most global ice sheets, including the LIS. They noted, however, that the LLGM of the various sectors of the LIS were asynchronous (albeit with large uncertainties), with some margins (e.g. in the south) potentially reaching their maximum early, perhaps even prior to, the gLGM and others occurring much later (e.g. the Maritime provinces in the southeast). Indeed, Dyke et al. (2002) suggested that ice advanced to its Late Wisconsinan (MIS 2) limit in the northwest, northeast and south about $27-28 \mathrm{ka}\left(23-24{ }^{14} \mathrm{C} \mathrm{ka}\right)$, and in the southwest and far north about $\sim 24-25 \mathrm{ka}\left(20-21{ }^{14} \mathrm{C} \mathrm{ka}\right)$. More recently, a number of studies have shown that ice sheet margin in the far north-west, in the vicinity of the Mackenzie River delta and along the Richardson Mountains, attained its maximum position relatively late and certainly less than $20 \mathrm{ka}$ (e.g. Murton et al., 2007; Kennedy et al., 2010; Lacelle et al., 2013), possibly as a short-lived advance between 17 and 15 ka (Murton et al., 2015). 
Thus, the consensus is that - overall - the LIS reached its local maximum extent early in the gLGM period (cf. Dyke et al., 2002), but with some margins advancing much later, e.g. in the far north-west. Most recent modelling experiments converge on maximum volumes 26-25 ka (e.g. Tarasov et al., 2012; Stokes et al., 2012; Abe-Ouchi et al., 2013), although some place it closer to 21-20 ka (e.g. Marshall et al., 2000).

It is very likely that the LIS existed at its near-maximum extent for several thousand years (cf. Dyke et al., 2002; Tarasov et al., 2012). Given that it grew to this position from a relatively large ice sheet late in MIS 3 (Dyke et al., 2002; Stokes et al., 2012; Tarasov et al., 2012), the prolonged duration of its maximal configuration suggests that, for the most part, it had a surface geometry and mass balance in equilibrium with the gLGM climate for a few thousand years (Dyke et al., 2002).

\subsection{Extent and thickness of the LIS at its Local Last Glacial Maximum (Late Wisconsinan)}

The maximum extent and thickness of the ice sheet during its Late Wisconsinan maximum has been the subject of debate for over 150 years (e.g. Bell, 1884) and, despite numerous studies on this subject, consensus has only recently emerged (Dyke et al., 2002). A comprehensive review of the literature on this subject is beyond the scope of this paper (see Ives (1978) and Dyke et al. (2002) for authoritative reviews), but it is useful to summarise key areas of contention and consider how different ideas have evolved and, more often than not, been revisited.

Much of the early work on the extent and thickness of the LIS during its LLGM (e.g. Bell, 1884; Daly, 1902; Coleman, 1920) focussed on the mountains of the east coast of Canada and argued that many of the highest peaks (e.g. the Torngat of northern Labrador) either remained as nunataks or were only affected by local ice caps or glaciers. This 'minimum' model was based on the identification of erosional trimlines (e.g. at $650 \mathrm{~m}$ in the Torngat Mountains, see Daly, 1902) and the presence of frost shattered bedrock and blockfields above these limits (e.g. Coleman, 1920). These interpretations were first questioned by Odell (1933) who reported high-level erratics and poorly preserved striations at $1446 \mathrm{~m}$ in the Torngat Mountains, thus arguing that the last ice sheet had overtopped the mountains, and that block-fields formed after deglaciation. Similar observations informed similar interpretations by Flint et al. (1942) in the Shickshock (Chic-Choc) Mountains, and Flint's hypothesis for the inception and growth of the LIS (Flint, 1943) called for a highland origin and windward-growth that subsequently inundated the high coastal mountains. This 'maximum' model (Fig. 1) was adopted in a series of major publications (e.g. Flint, 1947; 1971) and on a new 'Glacial Map of North America' (Flint et al., 1945), which was one of the first attempts (see also Chamberlin, 1913) to synthesise the glacial features in detail and on a large scale. An important corollary of Flint's 'maximum' model was that the ice sheet was viewed as a monolithic single-domed ice sheet centred over Hudson Bay, although earlier workers had suggested alternative multi-domed configurations (Tyrell, 1898; Coleman, 1920).

As noted by Ives (1978), Flint's maximum model appeared to have been widely accepted and clearly influenced the boundary conditions for the first CLIMAP (Climate: 


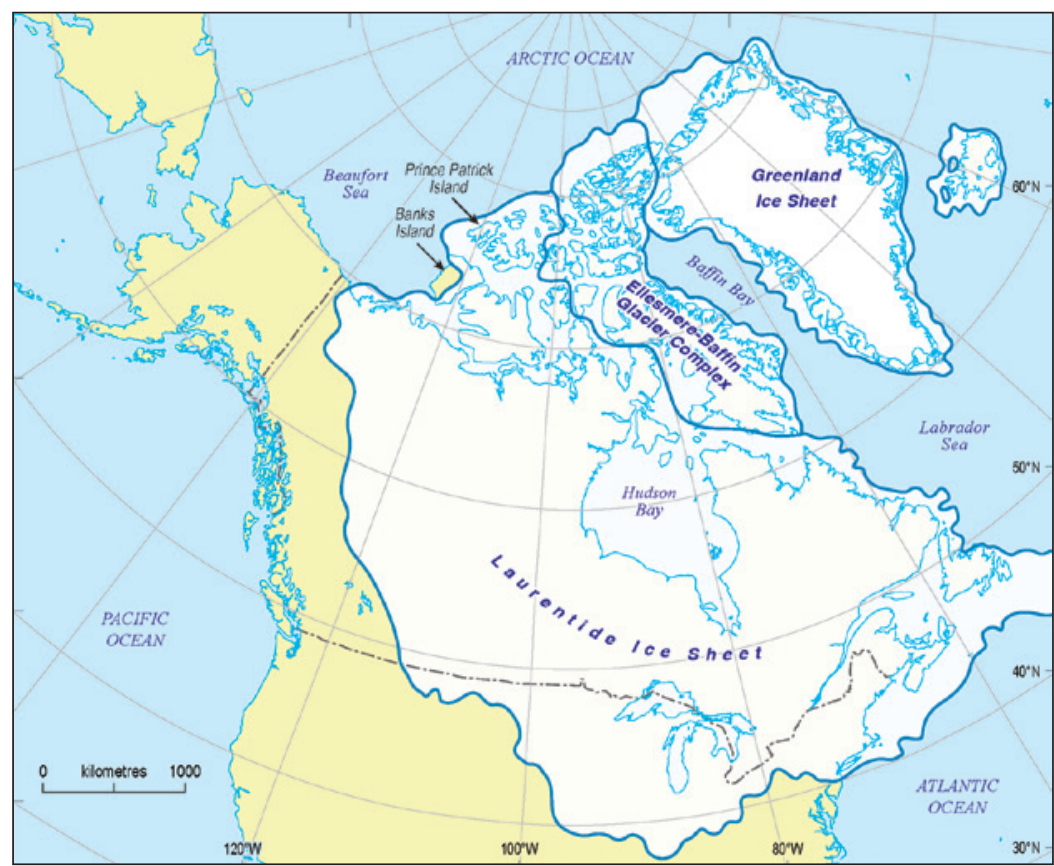

Figure 1. An outline of Flint's (1971) portrayal of the maximum extent of the Laurentide Ice Sheet east of the Cordillera during the Quaternary (simplified and redrawn from Ives, 1978). Note that the Cordilleran Ice Sheet was not depicted in the original version.

Long range Investigation, MApping, and Prediction) reconstruction of the 'Ice-Age' earth (CLIMAP, 1976; Denton and Hughes, 1981), in addition to becoming firmly entrenched in high school and University curricula. Indeed, when Prest (1969) produced one of the most detailed maps of the retreat of the ice sheet (discussed in Section 3; see Fig. 7), his Late Wisconsinan limit extended, for the most part, on to the continental shelf along the east coast from northern Baffin Island, all the way down to the Atlantic provinces, and covered most of the Canadian Arctic Archipelago (apart from Banks Island). He also depicted an extensive southern margin that transgressed well into northern USA and as far south at 40 degrees.

Despite the ascendency of the maximum model from the 1940s, a number of papers in the 1950s, 1960s and 1970s (Ives, 1957; Andrews and Miller, 1972; Miller and Dyke, 1974) had questioned it on the basis that several different 'weathering zones' could be distinguished by their relative maturity (see review in Ives, 1978), with the oldest weathering zones interpreted to pre-date the LLGM and indicating ice-free refugia. In some locations, this interpretation was further strengthened by a small number of radiocarbon dates that gave ages much older than the Late Wisconsinan (e.g. Løken, 1966). Those arguing for a return to a more minimal model interpreted the high-altitude erratics and evidence of glacial abrasion (e.g. Odell, 1933) to be from a much older (pre-Late Wisconsinan) glaciation, although it was becoming increasingly recognised that they might also have been preserved beneath more recent cold-based ice (e.g. Sugden, 1977; Sugden and Watts, 1977). 
Similar debates were being played out along other parts of the ice sheet margin, with multiple weathering zones and, in some cases, correlative till sheets being used to infer reduced ice sheet extent on the Queen Elizabeth Islands (England, 1976a, 1976b) and Banks Island (Vincent, 1982); and even at the south-western margin of the ice sheet, where drift previously thought to have been of Late Wisconsinan age was subdivided on the basis of morphological degradation, with the fresher drift delimiting the last ice cover (Stalker, 1977). Thus, in a comprehensive review of a rapidly-growing body of literature, and on the basis of a large amount of fieldwork carried out since the 1950s, Ives (1978) called for a return to the minimum model that had prevailed prior to the 1940s and with Late Wisconsinan limits well behind those proposed by Prest (1969) at the north, eastern and south-eastern margins of the ice sheet, i.e. with localised refugia around much of the ice sheet's perimeter and on the continental shelf. Ives (1978) also emphasised that the minimum model implied a much reduced ice thickness and that it was unlikely to have been a simple, monolithic dome with maximum ice thicknesses over Hudson Bay, as originally envisaged by Flint.

By the early 1980s, therefore, a large body of work had argued for a retraction of the Late Wisconsinan limit and "adherents of minimum ice sheet models" (e.g. Boulton et al., 1985: p. 452) adopted a more restricted margin, but this was not universally accepted and the debate continued (e.g. Hughes et al., 1977; Denton and Hughes, 1981). Indeed, Dyke and Prest, 1987) noted that Prest (1984) was unable to portray a single Late Wisconsinan limit that met with any consensus and he instead showed a minimum and maximum limit, with the maximum similar to his 1969 reconstruction.

It was in the context of this highly contentious body of literature, that Dyke and Prest (1987) produced one of the most influential reconstructions of the pattern and timing of the LIS that would act as a benchmark for several decades. Their maximum extent at $21.4 \mathrm{ka}$ $\left(18{ }^{14} \mathrm{C}\right.$ ka BP) was clearly influenced by the growing body of evidence for a retracted ice margin along the northern and eastern coasts of Canada, with the Torngat Mountains (and parts of the Appalachians, including the Shickshock Mountains) protruding as nunataks, and with large areas of Baffin Island and the Queen Elizabeth Islands ice-free, together with Banks Island (see Fig. 2). Acknowledging much larger uncertainty, Dyke and Prest (1987) also depicted major ice shelves in association with the Appalachian ice complex and others extending off the coast of Labrador, together with ice shelves in the Gulf of Boothia/Lancaster Sounds and in M'Clure Strait. Elsewhere, the southern margin (e.g. the Lake Michigan Lobe) extended south of 40 degrees (based on work by Clayton and Moran, 1982) and they depicted fully coalescent Laurentide and Cordilleran ice sheets at this maximum extent that was, at that time, far more controversial than it is now (cf. Stalker, 1977). A further significant component of the Dyke and Prest (1987) reconstruction was that it clearly portrayed a multi-domed configuration at its maximum, with centres of ice mass (domes) located over Labrador, Keewatin and Foxe Basin, and with major ice divides emanating from them (Fig. 2). This geometry attempted to reconcile new evidence from erratic dispersal trains that clearly indicated a complex multi-domed configuration (Shilts et al., 1979; Shilts, 1980). Dyke and Prest (1987) also discussed the importance of ice streams and the availability of 'soft' deformable sediments (cf. Fisher et al., 1985) in influencing the ice surface topography (see also Section 2.4), noting that many of the ice lobes at the southern margin of the ice sheet had extremely low ice surface gradients (Mathews, 1974). 


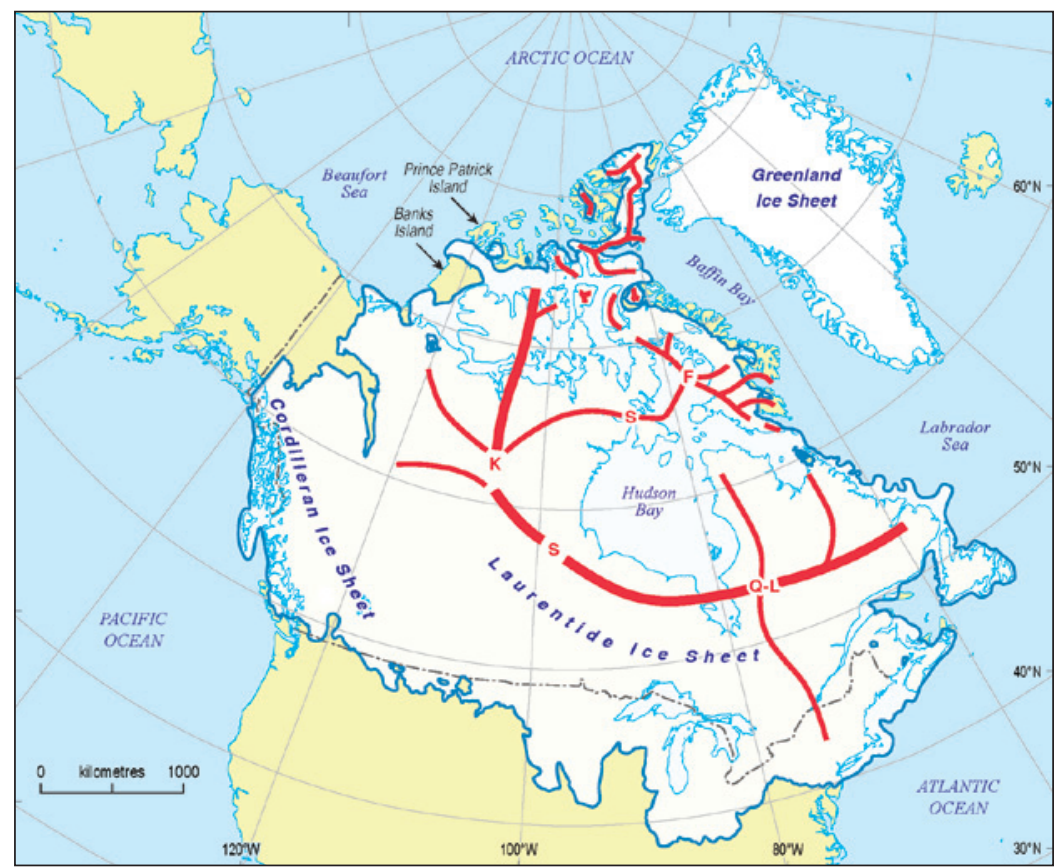

Figure 2. Reconstruction of the North American ice sheets at $21.8 \mathrm{ka}\left(18{ }^{14} \mathrm{C} \mathrm{ka}\right)$, simplified and redrawn from Dyke and Prest (1987). The three major domes of the LIS over Quebec/Labrador $(Q-L)$, Keewatin $(K)$ and Foxe Basin $(F)$ are labelled. Major ice divides shown in red with lowerlying 'saddles' in the ice sheet surface labelled ' $S$ '.

The pendulum swung again in the mid-1990s (cf. Miller et al., 2002) when new lines of evidence were uncovered to interpret a more extensive Late Wisconsinan limit than had been portrayed by Dyke and Prest (1987), particularly at is northern margin, but also along the eastern margin and in the Atlantic provinces. As noted by Dyke et al. (2002: p. 11): "after a century of debate, intensively for the last 25 years, about the existence of an Innuitian Ice Sheet during the LGM over the northern half of the Canadian Arctic Archipelago, a consensus has emerged that such an ice sheet did in fact cover most of that region". This was based on new glacial geological evidence of ice streams within several inter-island channels and large fjord systems (e.g. Blake, 1992, 1993; Dyke, 1999; Lamoureux and England, 2000; Ó Cofaigh et al., 2000) and numerous sets of lateral meltwater channels that descended to marine limits of early Holocene age (Dyke, 1999; England, 1999; England et al., 2000). This appeared to offer conclusive evidence that the Innuitian Ice Sheet (IIS) extended offshore at its maximum extent and that it was fully coalescent with the Greenland Ice Sheet along Nares Strait in the east, and with Laurentide ice along Parry Chanel in the south, which was originally proposed by Blake (1970) and illustrated by Prest (1969), see Fig. 3. The limits of the ice sheet in the north-west were much more uncertain, but Dyke et al. (2002) portrayed the whole of Prince Patrick Island as ice-free, and large parts of Melville Island and most of Banks Island as unglaciated (Fig. 3). 
The other region that benefitted from increased scrutiny from the mid-1980s onwards, particularly on the continental shelf, was the south-eastern margin of the ice sheet (cf. Miller et al., 2002). Dyke and Prest (1987) had portrayed large ice-free areas at the ice sheet's maximum extent, but new cosmogenic dating of intensively weathered terrains suggested that they could have been covered by cold-based ice (Gosse et al., 1995). New ${ }^{14} \mathrm{C}$ AMS radiocarbon ages from marine sediments on the continental shelf off Nova Scotia and southern Newfoundland also dated sediment above the youngest till to be of post-LGM ages (e.g. Amos and Knoll, 1987; Bonifay and Piper, 1988; Gipp and Piper, 1989; Mosher et al., 1989; Amos and Miller, 1990; Forbes et al., 1991; Gipp, 1994; King, 1996; Stea et al., 1998; Josenhans and Lehman, 1999). To the north, sedimentological studies and high-resolution AMS dating of marine sediment cores from the SE Baffin and Labrador shelves, and adjacent slopes, led to a reconsideration of LLGM ice extent in that region (Dyke et al., 2002). Jennings (1993), for example, concluded that Cumberland Sound was filled by an ice stream until $\sim 11.5 \mathrm{ka}\left(\sim 10{ }^{14} \mathrm{C} \mathrm{ka}\right)$ which Kaplan (1999) suggested may have extended onto the continental shelf (see also Miller et al., 2002). In northern Labrador, Clark and Josenhans (1990) combined marine and terrestrial evidence to suggest that LGM ice was more extensive than previously mapped, with the ice limit extending onto the continental shelf. Cosmogenic exposure dating (Marsella et al., 2000) also confirmed extensive Late Wisconsinan outlet glaciers in the fiords of Cumberland Peninsula.

Thus, numerous lines of evidence had been uncovered to suggest that previous assigned 'old' (pre-LGM) moraines on Cumberland Peninsula and northern Baffin Island were of Late Wisconsinan age, leading to the most significant re-interpretations of the ice extent along the north-eastern Laurentide margin for several decades, which was summarised in Dyke et al. (2002). The Late Wisconsinan extent portrayed in Dyke et al. (2002) (Fig. 3) was subsequently incorporated into the updated deglaciation sequence for North America (Dyke et al., 2003). This proposed LLGM extent has also been reproduced in more recent overviews and syntheses (e.g. Dyke, 2004) and the margin positions have been used as constraint data for numerical modelling of the LIS (e.g. Tarasov et al., 2012; Peltier et al., 2015).

The most dramatic changes to the LLGM extent of the LIS in the last decade has seen the ice margin extended to cover the $>70,000 \mathrm{~km}^{2}$ Banks Island in the Western Canadian Arctic (England et al., 2009; Lakeman et al., 2012, 2013) and the recognition that it likely extended to (or close to) the continental shelf edge in Baffin Bay (Briner et al., 2006) and in Atlantic Canada (Shaw et al., 2006) (see Fig 4). Banks Island had long been regarded as an ice-free refugium (Prest, 1969; Vincent, 1982; Dyke and Prest, 1987) and was portrayed as such in the most recent Dyke et al. (2003) synthesis (see also Dyke, 2004). A suite of new radiocarbon dates and glacial geomorphological mapping, however, has clearly indicated that the LIS inundated Banks Island during the LLGM (England et al., 2009; Lakeman et al., 2012, 2013). Similar methods and new dates have also extended the ice margin over the entirety of Melville Island and onto Eglington Island (Nixon et $a l ., 2014)$ and it is likely that the ice also overran Prince Patrick Island and extended onto the continental shelf along the entire IIS margin (see Stokes et al., 2016). At the same time, a large body of work has used cosmogenic dating of high-elevation erratics close to 


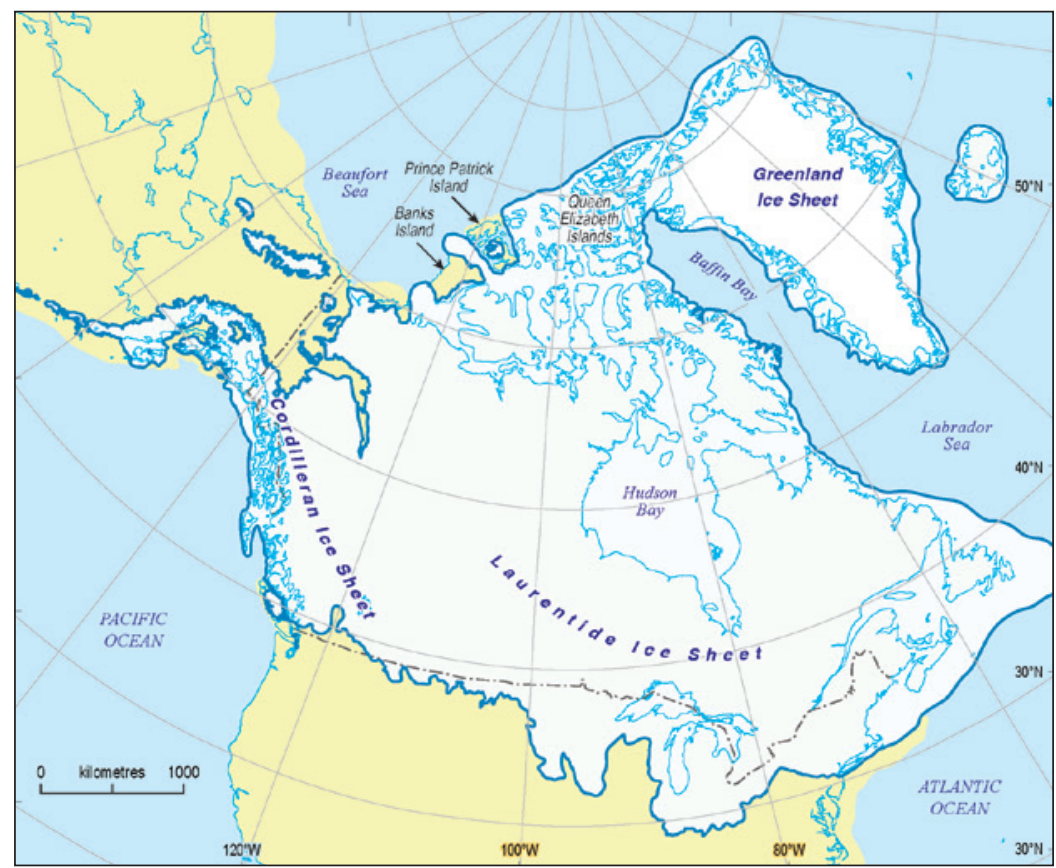

Figure 3. Revised reconstruction of the North American ice sheets at $21.8 \mathrm{ka}\left(18^{14} \mathrm{C} \mathrm{ka}\right)$ simplified and redrawn from Dyke et al. (2002). Note the increase in the areal extent of the ice sheet compared to Figure 2, especially over the Queen Elizabeth Islands and at the south-eastern margin (e.g. over Newfoundland), but with Banks Island and Prince Patrick Island remaining ice-free.

fjord mouths (e.g. on Baffin Island) to demonstrate that a relatively thick LIS must have terminated on the continental shelf during the LLGM (e.g. Briner et al., 2006), and with most high-elevation areas covered by non-erosive cold-based ice that accounts for the preservation of highly weathered surfaces in those locations. In the Atlantic provinces, a large body of work undertaken offshore has identified moraines, flutings, till tongues, cross-shelf troughs and associated trough mouth fans, which attest to warm-based ice streams extending to the edge of the continental shelf and separated by more stagnant ice on the shallow banks (e.g. Mosher et al., 1989; Piper and Skene, 1998; Schnikter et al., 2001; Shaw et al., 2006). It is also noteworthy that data-calibrated modelling of the North American Ice Sheet complex at the LLGM (Fig. 5) also generates a large multi-domed ice sheet that extends to the edge of the continental shelf, with some of these major ice streams (see Fig. 4) captured in the basal velocity pattern (Stokes and Tarasov, 2010).

In summary, after over 150 years, consensus appears to have been reached that at its Late Wisconsinan maximum ( 25-24 ka), the LIS was a large multi-domed ice sheet with a southern margin that extended south of $40^{\circ}$ in the Great Lakes region, with a western margin that was fully coalescent with the Cordilleran Ice Sheet, and with northern and eastern margins that extended to the edge of the continental shelf (Fig. 4). 


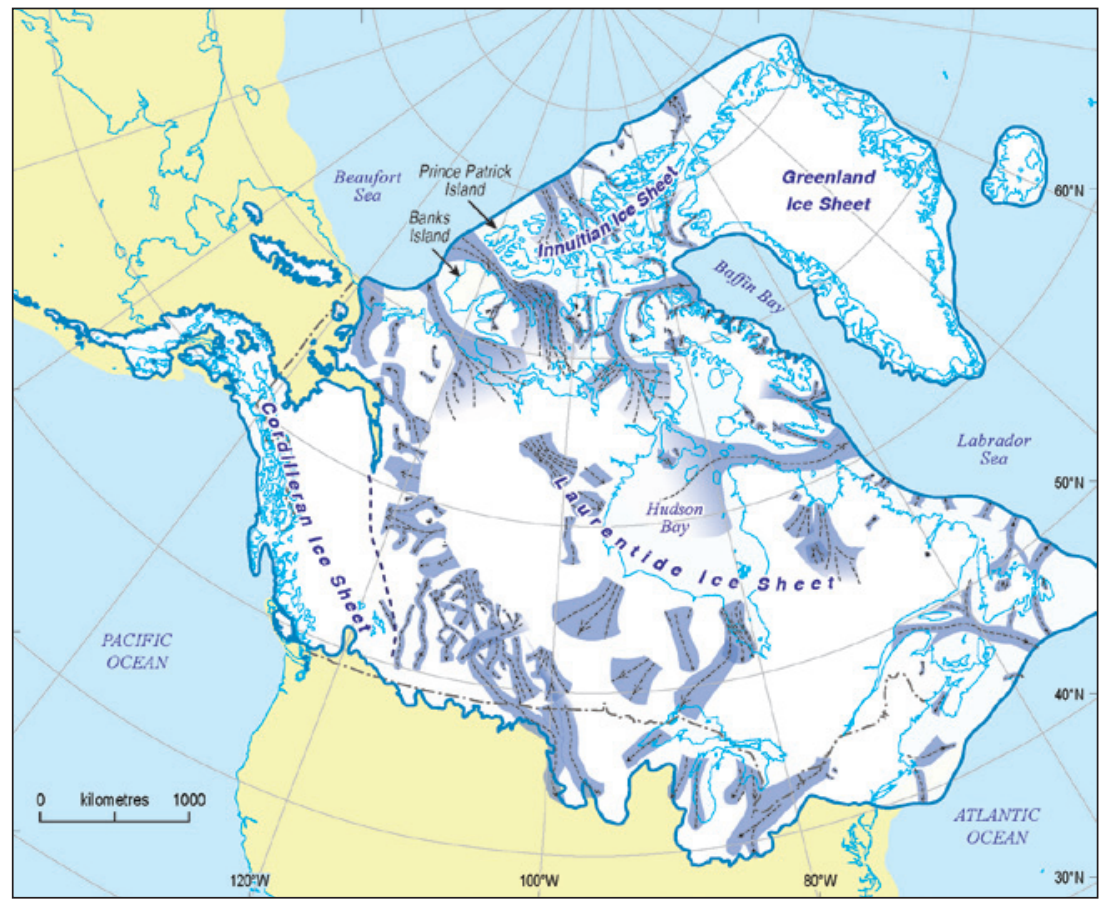

Figure 4. A recent reconstruction of the Laurentide Ice Sheet redrawn from Stokes et al. (2016). Note the expansion of the ice sheet margin over Banks and Prince Patrick Island. This reconstruction also includes the location of 117 hypothesised ice streams (dark blue with flowlines) in the Laurentide Ice Sheet based on published literature and new mapping in Margold et al. (2015a). Note that the ice streams did not all operate at the LLGM and that the inventory excluded the Cordilleran Ice Sheet.

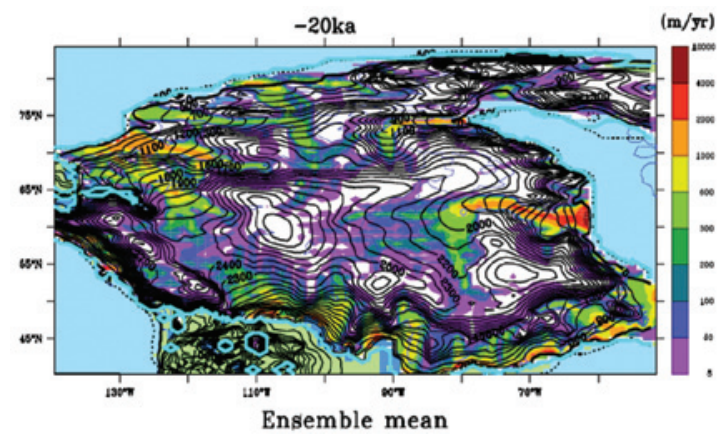

Figure 5. Weighted mean basal velocity and surface elevation of the North American Ice Sheet complex at 20 ka taken from Tarasov et al. (2012). Note that this ensemble is not representative of a single glaciologically-self-consistent model run and that the weighted averaging also blurs ice stream locations and magnitudes, and smooths ice surface topography. It is simply the expectation value. Note, however, that the mean captures some of the major ice-streams (compare with Figure 4) and most of the key features of the geologically inferred reconstruction of Dyke and Prest (1987) (Fig. 3). 


\subsection{Quantification of LIS volume at its Local Last Glacial Maximum (Late Wisconsinan)}

Quantifying the volume of the LIS is important for reconciling records of global sea level (Carlson and Clark, 2012; Lambeck et al., 2017), but this has often proved difficult due to the lack of nunataks and trimlines from interior regions (cf. Simon et al., 2014). As noted by Dyke et al. (2002: p. 20): "all that can be concluded from direct mapping is that the vast interior region of the ice sheet, generally the part that was more than about $1000 \mathrm{~km}$ behind the margin, lay more than $2000 \mathrm{~m}$ above present sea level". Thus, despite numerous studies and debates regarding the extent and geometry of the ice sheet (see Section 2.3), few have attempted to quantify its volume.

Paterson (1972) was one of the first to consider the theory of ice flow and relate the area of the ice sheet to its thickness and volume. Using previous maps of ice sheet extent (from Prest, 1969), that were informed by Flint's (1943) large monolithic reconstruction, he argued that the LIS may have been up to $3.6 \mathrm{~km}$ thick at its maximum and comprised $26.5 \times 10^{6} \mathrm{~km}^{3}$ of ice (with volume errors estimated at $16 \%$ ). During the 1980s, however, the importance of 'deforming beds' was becoming increasingly recognised (cf. Alley et al,. 1986; Boulton and Hindmarsh, 1987) and this clearly influenced attempts to reconstruct the LIS, with important implications for its volume. In particular, numerical modelling experiments (e.g. Fisher et al., 1985; Boulton et al., 1985) clearly showed that the incorporation of deformable beds with low basal shear stress beneath the ice sheet generated thinner ice and removed much of the radial symmetry of some of the earlier reconstructions (e.g. Flint, 1943). Indeed, the difference between Fisher et al.'s (1985) 'soft bed' and 'hard bed' models of the LIS was a volumetric reduction of around $30 \%$ for the former. The incorporation of deforming beds also generated multi-domed configurations that were deemed to be more compatible with the emerging geological evidence at that time (e.g. Shilts et al., 1979; Shilts, 1980; see Fig. 2). Later modelling work by Clark et al. (1996) and Licciardi et al. (1998) also demonstrated that a reduction in the effective viscosity of the till in regions underlain by 'soft' sediments generated a multi-domed ice sheet with a large bowl-shaped depression over Hudson Bay and thin ice $(\sim 1000 \mathrm{~m}$ above modern sea level) over the western and southern sectors of the ice sheet. A thinner, multi-domed ice sheet was also consistent with inverse modelling of crustal rebound and relative sea level data used in the early ICE-NG series (e.g. ICE-3G, Tushingham and Peltier, 1991; ICE-4G, Peltier, 1994).

More recently, Peltier's ICE-5G model of the ice load history (Peltier, 2004) indicated much larger ice sheet thicknesses over the Keewatin region $(>4 \mathrm{~km})$ and correspondingly larger volumes for the LIS. Tarasov et al. (2012) also noted that their modelled ice thicknesses over Hudson Bay were "possibly a kilometer too thick" (p. 37). Other work indicates thinner ice in this region (e.g. Lambert et al., 2006; Argus and Peltier, 2010; Mazzotti et al., 2011), including the most recent ICE-6G modelling (Peltier et al., 2015), which shows ice thickness over Keewatin that are $1.5 \mathrm{~km}$ thinner than ICE-5G (Vettoretti and Peltier, 2013). A suite of new radiocarbon dates that constrain the relative sea-level history of Arviat on the west coast of Hudson Bay are also consistent with a peak thickness of $\sim 3.4 \mathrm{~km}$ at the LLGM (Simon et al., 2014). 
Thus, although estimates of the LIS have varied quite dramatically over the last $\sim 100$ years, and this aspect of the ice sheet's history remains poorly constrained (see Lambeck et al., 2017), Table 1 indicates a convergence towards lower volumes in the more recent literature (cf. Abe-Ouchi et al., 2015), which are consistent with the influence of deforming beds and a thinner, multi-domed configuration (Fisher et al., 1985; Dyke and Prest, 1987; Clark et al., 1996; Marshall et al., 2000; Tarasov et al., 2012; Lambeck et al., 2017). At its Late Wisconsinan maximum, the LIS (including the IIS and the Appalachian Ice Complex) most likely contained around $20 \times 10^{6} \mathrm{~km}^{3}$, which is equivalent to $\sim 50 \mathrm{~m}$ of global sea level (Clark et al., 1996) (Table 1). This is around 500-1000 m lower in elevation than the original CLIMAP reconstructions (Denton and Hughes, 1981), which contained $34.2 \times 10^{6} \mathrm{~km}^{3}$ ( $85 \mathrm{~m}$ of global sea level), or around $75 \%$ more ice (Table 1).

Table 1. Chronological compilation of published estimates of the LIS extent, elevation and volume at its Local LGM (updated from Licciardi et al., 1998). Where indicated (*), note that some higher values are due to the inclusion of the Cordilleran Ice Sheet because separate values for the LIS were not quoted.

\begin{tabular}{|c|c|c|c|}
\hline Reference & $\begin{array}{c}\text { Extent } \\
\left(10^{6} \mathbf{k m}^{2}\right)\end{array}$ & $\begin{array}{c}\text { Maximum elevation } \\
\text { (km above present sea } \\
\text { level) }\end{array}$ & $\begin{array}{c}\text { Volume } \\
\left(\mathbf{x} 10^{6} \mathbf{k m}^{3}\right)\end{array}$ \\
\hline Ramsay (1931) & 15.75 & 2.9 & 45.45 \\
\hline Donn et al. (1962) & 12.74 & - & $31.85-25.48$ \\
\hline Andrews (1969) & 11.82 & - & 26.0 \\
\hline Flint (1971) & 13.39 & - & 29.46 \\
\hline Paterson $(1972)^{1}$ & 11.6 & 2.7 & 26.5 \\
\hline Sugden $(1977)^{1}$ & - & 3.5 & 37.0 \\
\hline Budd and Smith (1981) & - & $4-4.5^{*}$ & $<32 *$ \\
\hline 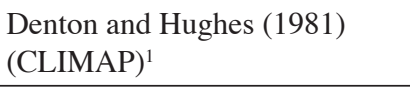 & - & $\begin{array}{l}3.8 \text { (max. model) } \\
3.5 \text { (min. model) }\end{array}$ & $\begin{array}{l}34.2 \text { (max. model) } \\
30.5 \text { (min. model) }\end{array}$ \\
\hline Boulton et al. $(1985)^{1}$ & - & $\begin{array}{l}\text { 3-3.5 (hard bed model }) \\
>3(\text { soft bed model })\end{array}$ & $\begin{array}{l}33-44 \text { (hard bed } \\
\text { model) } \\
\text { (soft bed not } \\
\text { reported) } \\
\end{array}$ \\
\hline Fisher et al. $(1985)^{1}$ & - & $\begin{array}{l}>3.2(\text { max. hard bed } \\
\text { model }) \\
>3.2(\text { min. hard bed } \\
\text { model }) \\
2.8-3.2(\text { soft-bed model })\end{array}$ & $\begin{array}{l}25.9 \text { (max. hard bed } \\
\text { model) } \\
21.1 \text { (min. hard bed } \\
\text { model) } \\
18.0 \text { (soft-bed } \\
\text { model) }\end{array}$ \\
\hline $\begin{array}{l}\text { Tushingham and Peltier (1991) } \\
(\text { (ICE-3G) })^{1}\end{array}$ & - & $>3$ & 21.0 \\
\hline Peltier (1994) (ICE-4G) ${ }^{1}$ & - & $\sim 3$ & 19.0 \\
\hline
\end{tabular}




\begin{tabular}{|l|l|l|l|}
\hline Clark et al. (1996) & - & $2-2.5$ & 19.7 \\
\hline Marshall and Clark $(1997 \mathrm{a}, \mathrm{b})^{2}$ & $\sim 14$ & 4.2 & 36.4 \\
\hline Licciardi et al. $(1998)^{1}$ & - & $\begin{array}{l}3.1 \text { (min. model) } \\
3.6 \text { (max. model) }\end{array}$ & $\begin{array}{l}15.9 \text { (min. model) } \\
19.7 \text { (max. model) }\end{array}$ \\
\hline Tarasov and Peltier $(1999)^{2}$ & $\sim 13^{*}$ & $\sim 3.8^{*}$ & $25^{*}$ \\
\hline Peltier (2004) (ICE-5G) & - & $>4$ & - \\
\hline Andrews (2006) & 12 & $3-4$ & - \\
\hline Tarasov et al. $(2012)$ & - & - & 28 (model nn9927) \\
\hline Gregoire et al. $(2012)$ & $\sim 16$ & $>3$ & $\sim 35^{*}$ \\
\hline Lambeck et al. $(2017)$ & & $\geq 3.5$ & \\
\hline
\end{tabular}

${ }^{1}$ Taken from Licciardi et al. (1998).

${ }^{2}$ Cited in Marshall et al. (2000).

\section{Pattern and timing of deglaciation}

It was not until the 1960 s that researchers attempted to systematically reconstruct the pattern and timing of deglaciation at the scale of the entire ice sheet and produce maps of the ice margins at specific time-steps (isochrones). One of the first attempts to undertake this was by Bryson et al. (1969) who utilised existing radiocarbon dates (289 in total) and geological information to plot the ice sheet perimeter at 500 to $1000 \mathrm{yr}$ intervals through time from about $13 \mathrm{ka}$ (Fig. 6). Key conclusions from that pioneering study were that the northern limit of the ice sheet lay close to the Arctic mainland coast of Canada, now known to be incorrect (see Section 2.3), and that the most dramatic retreat took place along the western margin, creating an ice-free corridor from the Arctic Ocean to the Great Plains around $10.1 \mathrm{ka}\left(9{ }^{14} \mathrm{C} \mathrm{ka}\right)$. They also noted that the LIS "retained its identity as a distinct unit" (p. 1) until around $8.4 \mathrm{ka}$, which they termed the Cockburn Phase. At the time, this was thought to be the "only major glacial pulsation" (Bryson et al., 1969: p. 7) that had been recognized stratigraphically and geomorphologically (e.g. major moraine systems) over large areas of the eastern and central Canadian Arctic (e.g. Falconer et al., 1965). It was significant because it represented the final phase of the contiguous LIS, with remnant domes over Keewatin, Labrador, and Foxe Basin-Baffin Island. By around $8 \mathrm{ka}$, however, Bryson et al. (1969) argued that marine incursion into Hudson Bay heralded the rapid disintegration of the ice sheet, with only a small ice cap surviving to present day (Barnes Ice Cap).

Around the same time, Prest et al. (1968) produced their Glacial Map of Canada, which summarised a vast amount of information and literature on the glacial geomorphology of the ice sheet. This was soon followed by Prest's impressively detailed map of the 'Retreat of Wisconsin and Recent Ice in North America' (Prest, 1969), which resembled Bryson et al.'s (1969) synthesis in many respects, but was far more detailed and with isochrones portrayed at a much higher temporal resolution (Fig. 7). So impressive was this compilation that an anonymous author in the journal Nature wrote that it "deserves a place on every class room wall where earth sciences 


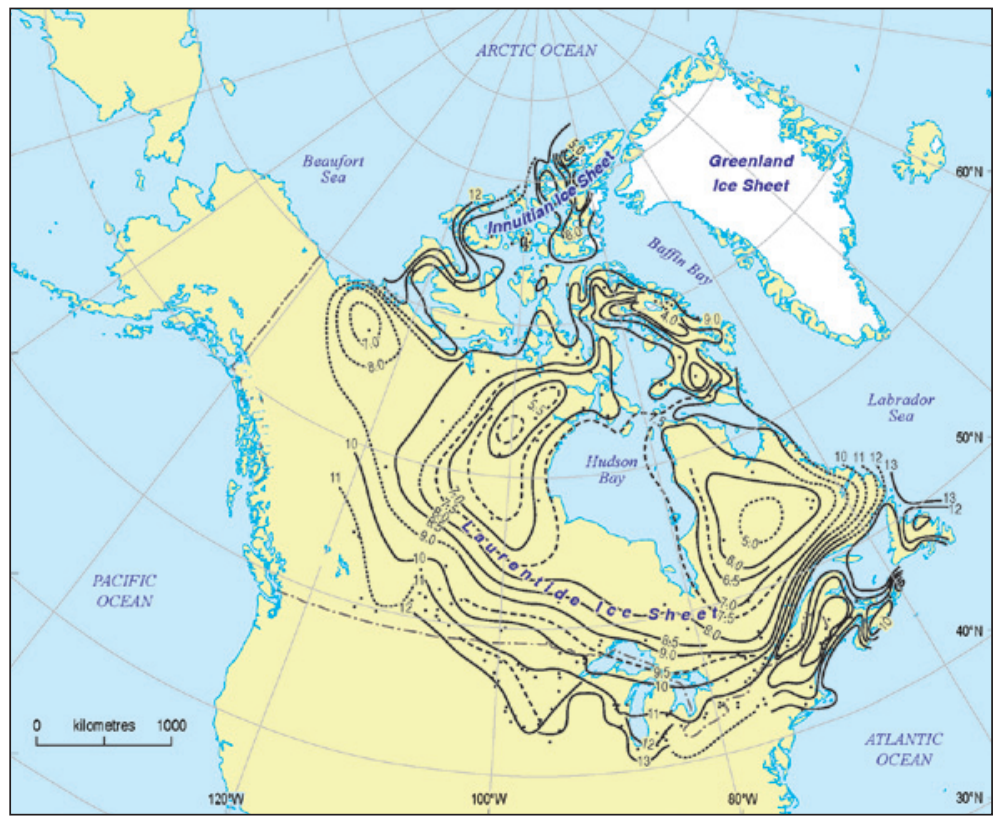

Figure 6. Radiocarbon-constrained isochrones of the retreat of the Laurentide Ice Sheet redrawn from Bryson et al. (1969). Note that ages are in ${ }^{14} C$ years BP. Dots indicate location of radiocarbon dates and dashed lines indicate larger uncertainty.

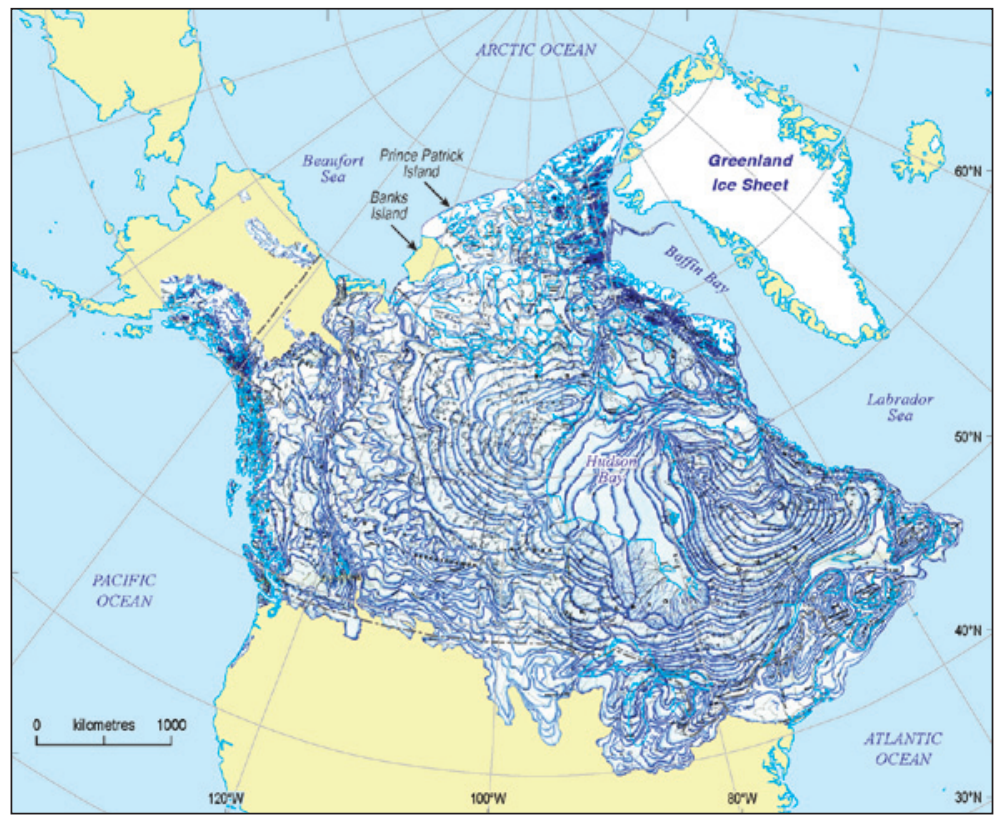

Figure 7. Reconstruction of the retreat pattern of the Laurentide and Cordilleran ice sheets redrawn from Prest (1969). 
and American archaeology are taught..." (Anonymous, 1970, p. 224). Denton and Hughes' (1981) impressive compendium on 'The Last Great Ice Sheets' also presented a continental-scale synthesis of the LIS, but with a particular focus on its configuration during the Late Wisconsinan and at 4-5 key time-steps during deglaciation (see Chapter 2: Mayewski et al., 1981). The next detailed synthesis of the ice retreat pattern was by Boulton et al. (1985). A key conclusion from their reconstruction was the rapid retreat of the southern margins and a very slow retreat at the northern margins of the LIS, perhaps reflecting a strong N-S climate gradient during deglaciation. They also noted that overall ice margin recession must have paused and that the margin maybe re-advanced at various locations during overall deglaciation.

Building on a large number of reports and maps on the glacial geology of Canada, much of it undertaken with impressive detail by the Geological Survey of Canada, Dyke and Prest (1987) produced their influential reconstruction of the pattern and timing of the LIS retreat (see Section 2.3). This comprised a series of palaeogeographic reconstructions at 11 time-steps (4 simplified examples are shown in Fig. 8) which included information on the ice sheet outline, geometry and associated changes in proglacial lake drainage and relative sea-level oscillations; and an accompanying map showing much higher resolution isochrones (Map 1702A: Dyke and Prest, 1987). In part, the paper was motivated by several debates that had emerged since Prest's (1969) map (Fig. 7), namely: (i) the location (extent) of the maximum Late Wisconsinan limit (see Section 2.3), (ii) the surface geometry of the ice sheet (i.e. the location of major ice domes and divides and their evolution through time), and (iii) the synchronicity of ice marginal fluctuations in the north versus the south (Dyke and Prest, 1987).

In many respects, Dyke and Prest's (1987) reconstruction has remained the benchmark for the last three decades, with the only major changes being the revisions to a more extensive Late Wisconsinan maximum at the LGM (see Section 2.3) and a refined ice margin chronology that has benefited from improvements in radiocarbon dating (mainly the advent of AMS dating methods) and the 'retirement' of hundreds of earlier conventional radiocarbon dates (see Dyke, 2004). The updated ice margin chronology is described in Dyke (2004) and is available in digital format in Dyke et al. (2003), which includes 36 time steps, starting $21.8 \mathrm{ka}\left(18{ }^{14} \mathrm{C} \mathrm{ka}\right)$ and ending at $0.9 \mathrm{ka}\left(1{ }^{14} \mathrm{C} \mathrm{ka}\right)$. This new chronology is based on $>4000$ dates that are spread across the entire ice sheet bed and consist of mainly radiocarbon dates, supplemented with varve and tephra dates, which constrain ice margin positions and shorelines of large glacial lakes. Dates on problematic materials (e.g. bulk samples with probable blended ages) were excluded in the Dyke et al. (2003) and Dyke (2004) chronologies and marine-shell dates, a major component, were also adjusted for regionally variable marine-reservoir effects on the basis of a new set of radiocarbon ages. The net effect is that deglaciation is delayed in most places by 500-2000 years with respect to the Dyke and Prest (1987) reconstructions (cf. Dyke, 2004). However, the spatial pattern of ice recession resembles earlier reconstructions and the pattern of deglaciation is described in Dyke and Prest (1987) and Dyke (2004), which form the basis of the following discussion and to which the reader is referred for more detail (see also the compendium in Fulton (1989), which covers several regions in impressive detail). The 
following sections present a broad overview of the pattern and timing of deglaciation at the continental scale, with potential driving mechanisms of these broad patterns discussed in Section 4.

\subsection{Local LGM to early Late Glacial: $\sim 25-17.6 \mathrm{ka}\left(18-14.5^{14} \mathrm{C} \mathrm{ka}\right)$}

Dyke and Prest's (1987) reconstruction at the LLGM included ice flow patterns that were informed by the distribution or glacial landforms (e.g. moraines, eskers and glacial lineations) on Prest et al.'s (1968) Glacial Map of Canada. Ice flowlines intersected the margin at right angles (unless they were in highly lobate areas with assumed divergent flow) and were followed back toward the centre of the ice sheet until features orientated in a different direction were encountered. A key feature of the LLGM ice flow pattern was the major ice stream in Hudson Strait that issued from a catchment area centred over Hudson Bay and with major domes over Quebec-Labrador to the south-east, Keewatin to the west and the Foxe-Baffin dome to the north (see Fig. 2). A major 'Trans-Laurentide Ice Divide' extended from near Victoria Island in the Canadian Arctic Archipelago south towards the Keewatin Dome and then westwards to connect with the Labrador dome, with secondary ice divides emanating from regional ice dispersal centres over the Queen Elizabeth Islands, Baffin Island, Newfoundland, and the Appalachians (Fig. 2). Dyke and Prest (1987) also depicted several major ice streams in regions where flow-lines exhibited strong convergence and they noted that some of these coincided with distinctive erratic dispersal plumes (e.g. Dyke et al., 1982; Dyke, 1984). Other ice streams were invoked at the southern margin of the ice sheet, associated with the major ice lobes that were known to have possessed very low ice surface gradients (cf. Mathews, 1974) as a result of deformable bed conditions beneath the ice sheet (e.g. Boulton et al., 1985; Fisher et al., 1985; see Section 2.4).

It is widely recognised that initial deglaciation from the LLGM configuration outlined above was generally slow during the first part of the period known as the Late Glacial (Dyke and Prest, 1987; Dyke et al., 2002) and that some margins may even have been advancing to their local maximum, e.g. at the far north-west (Kennedy et al., 2010; Lacelle et al., 2013; Murton et al., 2007,2015). Dyke et al. (2002) pointed out that there is little evidence of regional recession prior to $17 \mathrm{ka}\left(14{ }^{14} \mathrm{C} \mathrm{ka}\right)$, with the exception of the Atlantic Provinces, the Lake Michigan basin, the Mackenzie Lobe in the far north-west (cf. Harrington, 1989), and possibly in Hudson Strait, following Heinrich Event 2 (H2) (Andrews et al., 1998) (Fig. 8a). The Atlantic provinces underwent the most dramatic retreat during this period, where deglaciation was associated with a margin in deep water (Mosher et al., 1989; Piper et al., 1990; King, 1996; Scnitker et al., 2001; Shaw et al., 2006), and was perhaps triggered by eustatic sea level rise (Dyke, 2004).

Dyke (2004) also noted that the lobes of the southern margin were probably oscillating during slow net recession, but had retreated more substantially by the culmination of the Erie Interstadial, which is poorly dated, but which Dyke (2004) placed at around $18.8 \mathrm{ka}$ (15.5 ${ }^{14} \mathrm{C}$ ka, see Barnett, 1992). It has then been suggested that several of the Great Lakes ice lobes underwent a major readvance (several hundred kilometres) during the succeeding Port Bruce Stadial (e.g. Erie/Huron lobe, Des Moines lobe: Clayton and 

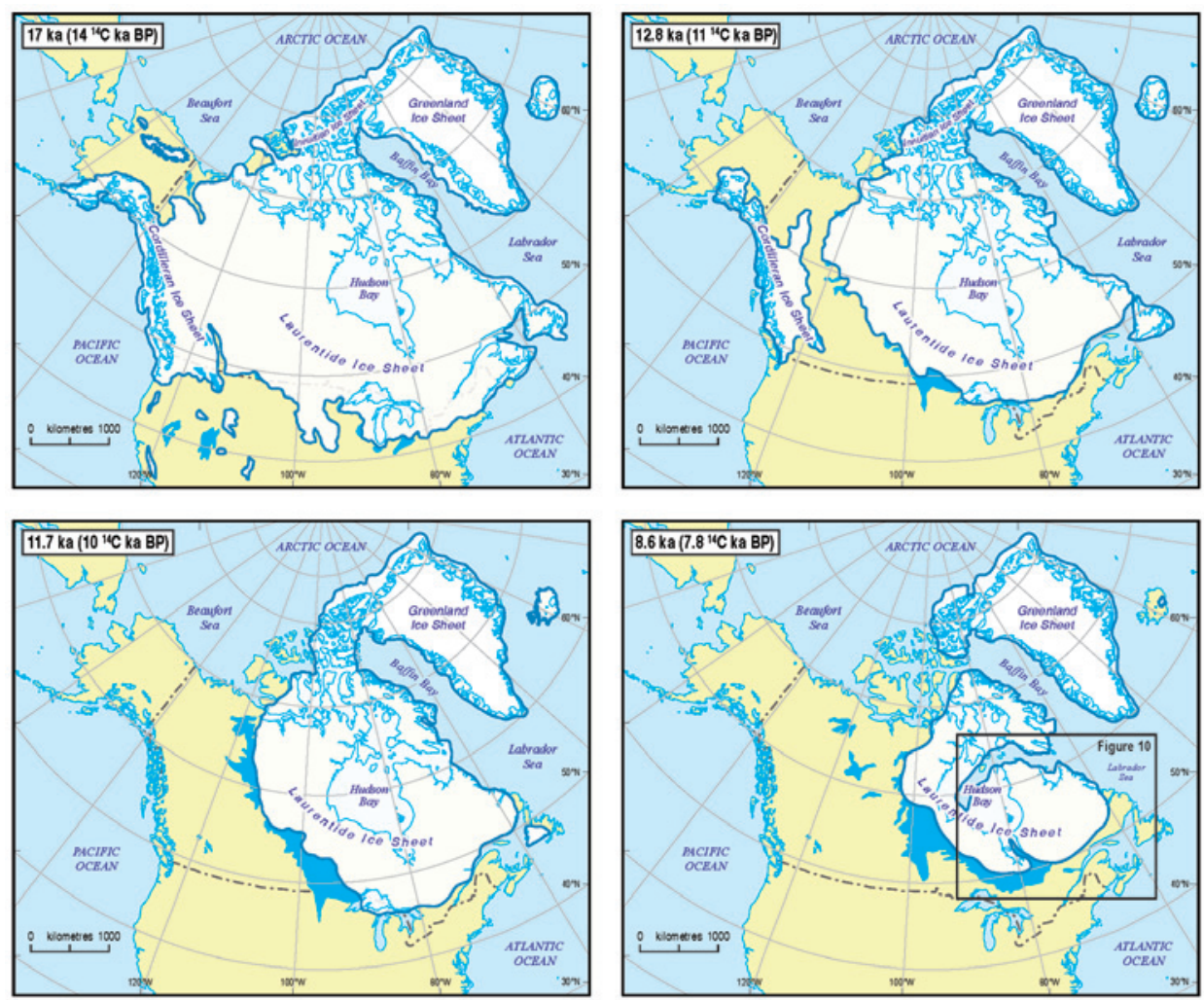

Figure 8. Examples of the reconstruction of the North American ice sheet during deglaciation redrawn from Dyke (2004): (a) $17 \mathrm{ka}$, (b) $12.8 \mathrm{ka}$, (c) $11.7 \mathrm{ka}$ and (d) $8.6 \mathrm{ka}$.

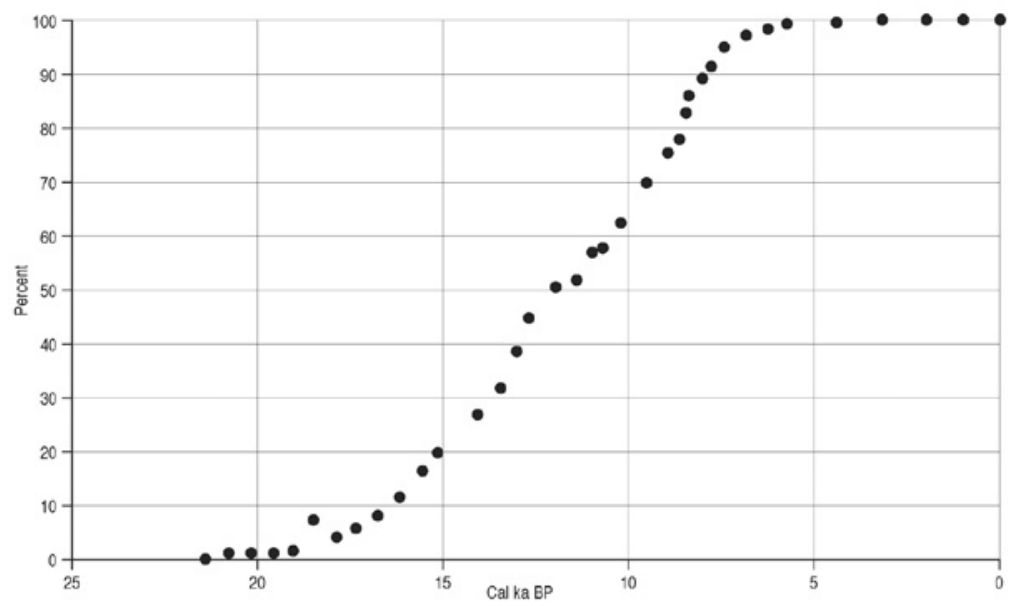

Figure 9. Percentage area deglaciated in North America compared to its Local Last Glacial Maximum, redrawn from Dyke (2004). 
Moran, 1982; Clayton et al., 1985) and produced the only net increase in ice extent during overall deglaciation (Dyke, 2004) (see Fig. 9). It is difficult to date correlative advances elsewhere in the ice sheet (see discussion in Dyke, 2004), but it is thought that they may also have taken place in Hudson Strait (Andrews et al., 2001) and perhaps in the Atlantic provinces (Miller et al., 2001; Shaw, 2003). Elsewhere, Dyke (2004) noted that an AMS date on wood from basal lake sediments in south-western Alberta (Beierle and Smith, 1998) indicates that initial decoupling of Laurentide and Cordilleran ice had begun by around $19 \mathrm{ka}\left(15.7{ }^{14} \mathrm{C} \mathrm{ka} \mathrm{BP}\right)$.

The fact that large-scale retreat of the LIS did not begin until around $16.8 \mathrm{ka}\left(14{ }^{14} \mathrm{C} \mathrm{ka}\right.$ : Dyke et al., 2002) is noteworthy because far-field sea-level records indicate that global sea levels had begun to increase a few thousand years prior to that time (Clark et al., 2009). Thus, it has been argued that if the LIS was contributing to sea-level rise in the early Late Glacial, then it must have been largely through thinning, rather than areal recession, and that this thinning and drawdown may have been associated with a transition from a thick, cold-based LGM ice sheet to thinner, warm-based ice sheet during early deglaciation (Marshall et al., 2000; Marshall and Clark, 2002; Robel and Tziperman, 2016). This transition may also have been manifest in a major internal flow re-organisation that may have been correlative with Heinrich event 1 (H1) around $17.7 \mathrm{ka}$ $\left(14.5{ }^{14} \mathrm{C}\right.$ ka) (see Veillette et al., 1999). Indeed, Dyke et al. (2002) noted that if this reorganisation occurred, it is likely that the drawdown of central ice surface would have promoted subsequent deglaciation by increasing the ELA. However, Dyke and Prest (1987) noted that changes in the ice marginal configuration between the LLGM and $17 \mathrm{ka}$ $\left(14{ }^{14} \mathrm{C} \mathrm{ka}\right)$ were insufficient to effect any permanent or substantial changes in the position of the primary ice domes and divides.

\subsection{Late Glacial Interstadial: 17.6-12.8 $\mathrm{ka}\left(14.5-11^{14} \mathrm{C} \mathrm{ka}\right)$}

This period includes the Bølling-Allerød warm interval, punctuated by the brief Older Dryas cold event (Lowe et al., 1994; Dyke, 2004). As noted by Dyke (2004), this period was associated with a clear pattern of net retreat of the LIS, particularly along the southern and western margins. It has also been pinpointed as a time of marked volume loss, particularly between $\sim 15$ and $14.5 \mathrm{ka}$ (Lambeck et al., 2017). Indeed, the LIS had likely become fully separated from the Cordilleran Ice Sheet (CIS) by the end of the Late Glacial Interstadial (Bølling-Allerød), whilst the northern and eastern margins of the ice sheet underwent only minimal recession (Fig. 8b) (Dyke and Prest, 1987; Dyke, 2004). Despite this asymmetric retreat, the overall configuration of the ice sheet geometry is thought to have changed little, with many of the major ice domes and divides remaining stable (Dyke and Prest, 1987). However, the marked retreat of the western margin of the ice sheet is likely to have driven an eastward migration of the main north-south M'Clintock Ice Divide and there were some marked changes in the regional ice flow directions over the interior plains (Dyke and Prest, 1987; Ó Cofaigh et al., 2009; Ross et al., 2009). It is also noticeable that this broad time interval was associated with the development of numerous glacial lakes along the western and southern margin of the ice sheet (Dyke and Prest, 1987; Fig. 8b). 
The timing of the opening of the ice-free corridor between the LIS and CIS has been the subject of much debate, largely due to its importance as a potential route for the peopling of North America (e.g. Dixon, 1999; Goebel et al., 2008; Eriksson et al., 2012; Pedersen et al., 2016), but also in relation to the routing of meltwater from Glacial Lake Agassiz (Smith and Fisher, 1993; Fisher and Smith, 1994; Fisher et al., 2002; Tarasov and Peltier, 2005; Murton et al., 2010; Fisher and Lowell, 2012; Teller, 2013; see Section 3.3). The rapid collapse of the saddle between the LIS and CIS has also been hypothesised as a potential source of meltwater pulse 1A (Gregoire et al., 2012, 2015a), although the precise contributions from North America are subject to ongoing debate (Clark et al., 2002; Carlson and Clark, 2012; Deschamps et al., 2012).

Dyke and Prest's (1987) reconstruction showed the ice free corridor opening up $\sim 15.6 \mathrm{ka}\left(13{ }^{14} \mathrm{C} \mathrm{ka}\right)$ and with the western margin of the LIS some $200-600 \mathrm{~km}$ east of the Cordilleran Mountains by $\sim 12.9 \mathrm{ka}\left(11{ }^{14} \mathrm{C} \mathrm{ka}\right)$ (Fig. 8b). This conflicts with some arguments that were later put forward (e.g. Dixon, 1999) that suggested that the ice sheets must have been fully-coalescent until quite late in the interstadial ( $12.9 \mathrm{ka})$. Recently, Lambeck et al. (2017) have also argued that any ice-free corridor is unlikely to have existed prior to $13 \mathrm{ka}$, using a new model of glacial rebound based on relative sea level data and the tilting of glacial lake shorelines. A similar conclusion was reached by Pedersen et al. (2016) who obtained radiocarbon dates, pollen, macrofossils and metagenomic DNA from lake sediment cores along the central portion of the corridor and found that it was not likely to be viable as a migration route before $12.6 \mathrm{ka}$. Unfortunately, this 'unzipping' of the two ice sheet remains very poorly dated. Dyke (2004) argued that the southern margin probably began opening around $18.2 \mathrm{ka}\left(\sim 15{ }^{14} \mathrm{C} \mathrm{ka}\right)$ and that it is possible that it may have opened completely by $\sim 16.3 \mathrm{ka}\left(13.5{ }^{14} \mathrm{C} \mathrm{ka}\right)$, based on radiocarbon dating of basal sediment in glacial Lake Peace (Catto et al., 1996), situated mid-way along the corridor from south to north. However, Dyke (2004) concluded that this scenario is unlikely and that the northern part of the corridor probably deglaciated later and around $14.7-13.9 \mathrm{ka}\left(12.5-12{ }^{14} \mathrm{C} \mathrm{ka}\right)$. A new analysis of available dates has attempted to constrain the minimum timing of the opening of the ice-fee corridor and suggests that it must have been completed by 11 ka (Gowan, 2013).

Elsewhere, the Late Glacial Interstadial is characterised by oscillations of the ice lobes at the southern margin of the ice sheet, superimposed on net recession, especially in the vicinity of the Great Lakes (Dyke, 2004). Ice margin retreat has been tracked at a remarkably high resolution $(<100$ years) in numerous glacial lake sequences that were deposited as various basins became isolated (e.g. Karrow and Calkin, 1985). Many of these sequences record the initiation of retreat at $\sim 17 \mathrm{ka}\left(14{ }^{14} \mathrm{C} \mathrm{ka}\right)$, but it was clearly punctuated by readvances of the ice margin that blocked drainage routes of glacial lakes. For example, the large readvance of the Lake Michigan Lobe around 13.6 to $12.3 \mathrm{ka}$ (11.8 to $11.5^{14} \mathrm{C} \mathrm{ka}$ ) is thought to have diverted water away from a westward route into the Labrador Sea and back towards the Mississippi drainage basin and the Gulf of Mexico (Dyke, 2004).

\subsection{The Younger Dryas (YD): 12.9-11.7 ka $\left(11-10{ }^{14} \mathrm{C} \mathrm{ka}\right)$}

Ice recession during the YD was generally slow, particularly at the northern and eastern margins of the ice sheet, where deglaciation mostly occurred after this period 
(Fig. 8) (Andrews, 1973; Dyke, 2004). However, the clear asymmetry of the retreat pattern (cf. Andrews, 1973) continued to drive the main M'Clintock Ice Divide (running north from the Keewatin dome: Fig. 2) and the ancestral Keewatin Ice Divide eastward (Dyke and Prest, 1987). Indeed, Dyke and Prest (1987) also noted that the period beginning around $11.5 \mathrm{ka}\left(10{ }^{14} \mathrm{C} \mathrm{ka}\right)$ marked the beginning of the demise of the main Trans Laurentide Ice Divide and increased the autonomy of the regional ice dispersal centres.

Although it was barely mentioned in comprehensive treatments of North American deglaciation prior to the late 1980s (Fulton, 1989), the Younger Dryas (YD) cold event is now known (cf. Dyke, 2004) to have been characterised by a period of moraine construction and, in several places, major readvances of the ice margin and ice marginal lobes (e.g. Dyke and Savelle, 2000). Such readvances have been well-documented along several parts of the ice sheet margin and include the large Gold Cove readvance from Labrador across Hudson Strait (Miller and Kaufman, 1990) and major readvances at the north-western margin of the ice sheet in the Canadian Arctic Archipelago (Dyke and Savelle, 2000). In many places, such readvances were associated with major ice lobes/ice streams, such as the Cumberland Sound Ice Stream on Baffin Island (Jennings et al., 1996; Andrews et al., 1998) and the M'Clintock Channel ice stream on Victoria Island (Hodgson, 1994; Stokes et al., 2009). As Dyke (2004) noted, although some moraines are clearly distinguishable as of YD age, others are likely to be correlative, but have not been precisely dated.

Any discussion of the LIS retreat during the YD warrants a mention of the drainage routes of glacial Lake Agassiz, which has been implicated as causative mechanism of this abrupt climatic reversal (Broecker et al., 1989). Initially, glacial Lake Agassiz drained to the south and into the Gulf of Mexico via the Mississippi River. The traditional model (cf. Dyke, 2004; Carlson and Clark, 2012) is that retreat of the Lake Superior Lobe after $\sim 12.9 \mathrm{ka}$ (Fig. 8b) allowed glacial Lake Agassiz to drain rapidly towards the east via the St Lawrence River and into the North Atlantic Ocean (Broecker et al., 1989; Dyke, 2004). This may have released up to $9,500 \mathrm{~km}^{3}$ of water, which is thought to have been capable of disrupting the North Atlantic's Meridional Overturning Circulation (AMOC) and instigating the YD cooling (Broecker et al., 1989; Dyke, 2004). Following the initial outburst, the eastward drainage is thought to have continued until it was blocked by ice during the Marqueette readvance, which culminated around $11.5 \mathrm{ka}\left(10{ }^{14} \mathrm{C} \mathrm{ka}\right)$ (Dyke, 2004). It is then thought that the drainage route may have switched northwards via the Clearwater spillway and towards the Arctic Ocean, via glacial Lake McConnell (Smith and Fisher, 1993; Fisher and Smith, 1994; Fisher et al., 2002). The drainage is then thought to have switched back to its original southward route until the recession of ice north of Lake Superior once again opened the westward route (Teller and Thorleifson, 1983). More recently, however, an alternative model has been suggested which indicates that Lake Agassiz may have drained to the northwest and into the Arctic Ocean much earlier than originally thought, and at the onset of the Younger Dryas (Murton et al., 2010). This is based on the dating of sands associated with the Mackenzie delta and upstream gravels and erosional channels (Murton et al., 2010), but numerical modelling has also indicated increased runoff 
via this outlet around this time, even in the absence of any lake drainage (Tarasov and Peltier, 2005). Furthermore, high-resolution ocean modelling indicates that freshwater input to the Arctic Ocean is much more effective at perturbing the AMOC compared to an input from the eastern drainage route (Condron and Winsor, 2012). Field evidence for the opening of the Clearwater spillway at the onset of the YD is, however, far from equivocal (Fisher and Lowell, 2012) and the debate continues.

\subsection{Final deglaciation: 11.5-6 $\mathrm{ka}\left(10-5.2{ }^{14} \mathrm{C} \mathrm{ka}\right)$}

Final deglaciation of the LIS occurred during the early to middle Holocene (11.5-6.0 ka) in response to increased summer insolation and increasing levels of carbon dioxide $\left(\mathrm{CO}_{2}\right)$ (Carlson et al., 2007; 2008; Marcott et al., 2013). This warming led to the disappearance of most Northern Hemisphere ice sheets, but Ullman et al. (2016) noted that, despite this strong radiative and temperature forcing, global mean sea level (GMSL) was still around $60 \mathrm{~m}$ below present at the start of the Holocene (Lambeck et al., 2014), indicating a lag (of as much as $4 \mathrm{ka}$ ) between deglaciation of the LIS and peak insolation and $\mathrm{CO}_{2}$ forcings (see also Section 4.1).

Retreat of the LIS was most dramatic along the northern and western margins of the ice sheet. Recession of the northern margin of the ice sheet accelerated dramatically soon after $11.5 \mathrm{ka}\left(10{ }^{14} \mathrm{C} \mathrm{ka}\right)$ and it is thought that the LIS and IIS had separated by $10.1 \mathrm{ka}\left({ }^{14} \mathrm{C} \mathrm{ka}\right)$, but that the IIS remained confluent with the Greenland Ice Sheet until $8.6 \mathrm{ka}\left(7.8{ }^{14} \mathrm{C} \mathrm{ka}\right.$ ) (Fig. 8c, d) (England, 1999; Dyke, 2004). Dyke (2004) suggests that the IIS had fragmented by $9.5 \mathrm{ka}\left(8.5^{14} \mathrm{C} \mathrm{ka}\right)$ and had retreated close to modern ice margins by $8.6 \mathrm{ka}\left(7.88{ }^{14} \mathrm{C} \mathrm{ka}\right)$. Dyke (2004) also noted that the Keewatin Sector of the ice sheet had cleared the Canadian Arctic Archipelago by $8.6 \mathrm{ka}\left(7.8{ }^{14} \mathrm{C} \mathrm{ka}\right)$ (Dyke, 2004). Retreat across the mainland was also rapid, but the ice sheet constructed a series of major moraine systems (e.g. the MacAlpine and Chantrey moraines) that Dyke (2004) assigned to around 9.1 to $8.6\left(8.2\right.$ to $7.8{ }^{14} \mathrm{C} \mathrm{ka}$ ). These moraines lie well inland of the marine limit and likely represent some form of readvance of the ice margin, perhaps associated with ice streaming (e.g. Stokes and Clark, 2003), rather than what Dyke (2004) referred to as 'end-of-calving' stabilisations in the Labrador Sector (see below).

Recession of the southern margin of the ice sheet was also rapid and has been reconstructed with impressive detail from tracing glacial lake shorelines to end moraines (e.g. Barnett, 1992). As the ice margin retreated into an isostatically-depressed interior, numerous lakes were decanted and their drainage re-routed, including a major eastward discharge of Lake Agassiz at around $10.1 \mathrm{ka}\left(9{ }^{14} \mathrm{C} \mathrm{ka}\right)$ (Dyke, 2004). These lakes may also have facilitated localised readvances of the ice margin (often termed 'surges' or ice streaming), such as into glacial Lake Ojibway (Thorleifson et al., 1993) and help explain the contrasting dynamics of neighbouring lobes during overall ice margin retreat (Cutler et al., 2011).

The final evolution of lakes Agassiz and Ojibway after $8.9 \mathrm{ka}\left(8{ }^{14} \mathrm{C} \mathrm{ka}\right)$ is more speculative, but their northwards drainage into the Tyrrell Sea (ancestral Hudson Bay) 
is evidenced by glacial bedforms, subglacial drainage channels and numerous iceberg scour-marks (Josenhans and Zevenhuizen, 1990). Josenhans and Zevenhuizen (1990) argued that a large calving bay opened up in western Hudson Bay and that glacial lakes Agassiz-Ojibway initially drained into that region, rather than eastern Hudson Bay. The final catastrophic drainage of the Agassiz-Ojibway and the full incursion of the Tyrrell Sea has been dated to around 8.4 to $8.2 \mathrm{ka}$ (Dyke, 2004), which is correlative with the ' $8.2 \mathrm{ka}$ cold event' seen in Greenland ice cores (Alley et al., 1997; Barber et al., 1999; Rasmussen et al., 2006). Indeed, Barber et al. (1999) have argued that the sudden release of freshwater that accompanied this event is likely to have disrupted the AMOC and lead to the abrupt but short-lived cooling seen in numerous circum-North Atlantic records. Elsewhere, Dyke (2004) noted that the western margin of the Québec-Labrador ice cap had stabilised at the 800-km long Sakami moraine (Fig. 10), most likely as a result of the sudden and large reduction of water depth that was accompanied by drainage of Lake Ojibway (Hardy, 1982).

In contrast to the rapid retreat seen elsewhere, Dyke (2004) suggests that the Baffin Sector was still close to its maximum configuration at $11.5 \mathrm{ka}\left(10{ }^{14} \mathrm{C} \mathrm{ka}\right)$ and that retreat of many of its outlet glaciers proceeded slowly between $11.5 \mathrm{ka}\left(10{ }^{14} \mathrm{Cka}\right)$ and $9.5 \mathrm{ka}\left(8.5{ }^{14} \mathrm{C} \mathrm{ka}\right)$. A series of extensive moraine systems were also constructed around much of the Baffin Sector between $9.5 \mathrm{ka}\left(8.5{ }^{14} \mathrm{C} \mathrm{ka}\right)$ and $7.8 \mathrm{ka}\left(7{ }^{14} \mathrm{C} \mathrm{ka}\right)$, which Dyke (2004) suggests may reflect a mass balance that fluctuated from positive to slightly negative. That said, it is clear that some major outlet glaciers retreated rapidly during this period, especially through deep bathymetric troughs (Briner et al., 2009), and Dyke and Prest (1987) portray the first major recession of the terminus of the Hudson Strait Ice Stream at $10.1 \mathrm{ka}\left(9{ }^{14} \mathrm{C} \mathrm{ka}\right)$.

Dyke (2004) argued that the final break-up of the Foxe-Baffin Sector likely involved the northward progression of a calving bay from Hudson Bay between 7.8 and $6.9 \mathrm{ka}$ (Fig. 8d) (7 to $6{ }^{14} \mathrm{C} \mathrm{ka)}$, leaving residual ice caps on Baffin Island, Southampton Island, and Melville Peninsula that remain the last major remnants of the LIS. Deglaciation of the remnant Keewatin and Foxe Domes (Dyke, 2004; Ross et al., 2012; Simon et $a l ., 2014)$ left a remnant Labrador Dome that has been estimated to contain a sea level equivalent of $3.6 \pm 0.4 \mathrm{~m}$ at $\sim 8.2 \mathrm{ka}$ (Ullman et al., 2016) (Fig. 10). Recently, Ullman et al. (2016) constrained the final retreat of this ice mass using ${ }^{10} \mathrm{Be}$ surface exposure dating and demonstrated that the ice margin may have been highly sensitive to several abrupt climate events. Superimposed on overall retreat, they demonstrated that the ice sheet deposited a series of moraine systems at $\sim 10.3 \mathrm{ka}$ (Paradise Moraine), $9.3 \mathrm{ka}$ (North Shore Moraine) and $8.2 \mathrm{ka}$ (Sakami Moraine) (Fig. 10), which coincided with North Atlantic cold events (Bond et al. 1997; Rasmussen et al., 2006), and which may have helped to stabilise the ice sheet. Following the widely-documented 8.2 ka event (see also Alley et al., 1997; Barber et al., 1999) and the opening of Hudson Strait, they suggest that Hudson Bay became seasonally ice-free and that the majority of the ice sheet melted abruptly and within a few centuries, with deglaciation of the LIS completed by $6.7 \pm 0.4 \mathrm{ka}$ (Fig. 10) (cf. Carlson et al., 2007; 2008). Indeed, using a Regional Climate Model, Ullman et al. (2016) argued that the loss of ice over Hudson Bay would have been important in driving negative mass balances in the surrounding ice masses, largely due to the increased thermal capacity and reduced albedo of seasonally open water. 


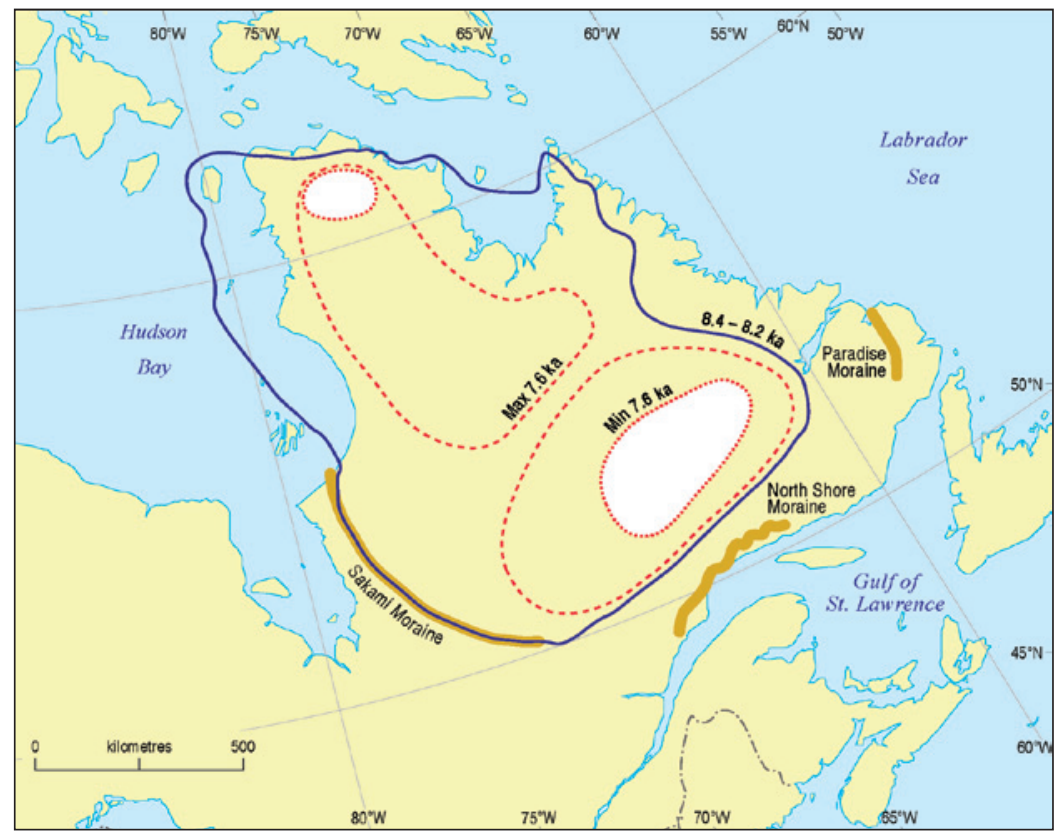

Figure 10. Reconstructed limits of the final deglaciation of the LIS in Quebec/Labrador, redrawn from Ullman et al. (2016). Blue lines show Dyke's (2004) reconstruction at 8.4-8.2 ka and red lines show maximum (dashed) and minimum (dotted) 7.6 ka ice areas from Ullman et al. (2016) in relation to the Sakami, North Shore, and Paradise moraines (see Occhietti et al., 2011).

\subsection{Summary}

The pattern and timing of the LIS deglaciation is now reasonably well-known and is characterised by a clear asymmetry whereby the western and southern margins retreated back towards major dispersal centres over Foxe Basin and Labrador. In terms of the timing, deglaciation is characterised by a period of very slow recession prior to $\sim 17 \mathrm{ka}$, when it lost $<10 \%$ of its area, followed by a near-linear retreat until $\sim 7.8 \mathrm{ka}$, when only $10 \%$ of the area remained more glaciated than present (Fig. 8, 9) (Dyke, 2004). Although there were numerous local-scale ice marginal fluctuations marked by rapid advance or retreat and internal flow reorganisation, the two most important events that interrupted the overall linear recession were: (i) the reduced rate of recession during the YD (including several well-documented readvances), and (ii) the final increased rate of recession during marine incursion into Hudson Bay (Dyke, 2004).

\section{Climatic forcing and mechanisms of LIS deglaciation}

As noted in the Introduction, palaeo-ice sheets represent a valuable analogue for understanding the rates and mechanisms of ice sheet deglaciation. Mass loss from ice sheets is complex, but can be broadly partitioned (cf. van den Broeke et al., 2009) between 
melting (mostly at the surface, but also under the ice sheet and where it meets the ocean), and a 'dynamic' component whereby rapidly-flowing outlet glaciers transfer ice from the interior to the oceans. In the Greenland Ice Sheet (GrIS), these processes are thought to be contributing approximately equally to its recent negative mass balance (van den Broeke et al., 2009). In Antarctica, however, there is much less surface melt and dynamic changes, namely the acceleration, thinning and retreat of outlet glaciers (Pritchard et al., 2009), are a more important influence on its mass balance, which is negative in West Antarctica but negligible or even slightly positive in East Antarctica (Shepherd et al., 2012). The extent to which surface mass balance and 'dynamic' discharge (ice streaming) influenced the deglaciation of the Laurentide Ice Sheet will now be discussed.

\subsection{Surface mass balance during deglaciation of the LIS}

In their discussion of the timing of the gLGM, Clark et al. (2009) argued that the primary mechanism for triggering the onset of deglaciation in the Northern Hemisphere between 20 and $19 \mathrm{ka}$ was increased insolation from orbital forcing. The efficacy of this external forcing is via increased surface melt in marginal areas, particularly at the southern margin of the LIS. Clark et al. (2009) also noted that once deglaciation had been initiated, it is likely that several feedback mechanisms would have amplified the initial response (e.g. involving albedo, $\mathrm{CO}_{2}$ and oceanic feedbacks), including a delayed crustal rebound, which keeps the ice sheet elevation relatively low and increases ablation (Abe-Ouchi et al., 2013). Recent modelling by Gregoire et al. (2015b) has attempted to partition the influence of increasing greenhouse gases (GHGs, e.g. $\mathrm{CO}_{2}$ ) and orbital forcing on North American deglaciation. They found that orbital forcing explains around $50 \%$ of the reduction in ice volume during deglaciation, while GHGs explain around $30 \%$, but that the impact of GHGs lags orbital forcing. Orbital forcing begins around 23 $\mathrm{ka}$ and starts to impact the ice sheet from around $19 \mathrm{ka}$, but there is a delay of $3 \mathrm{ka}$ before $\mathrm{CO}_{2}$ forcing has a noticeable influence from around $16 \mathrm{ka}$.

Recently, Ullman et al. (2015a) pinpointed the initial retreat of the southern margin of the ice sheet in Wisconsin using a suite of ${ }^{10} \mathrm{Be}$ surface exposure ages from boulder surfaces in terminal moraines. These ages dated the initial retreat of the ice margin from the LLGM moraines to $23.0 \pm 0.6 \mathrm{ka}$, which they noted was synchronous with several other locations along the southern margin and coincided with the initial increase in summer insolation around 24-23 ka. They also pointed out that an acceleration in retreat after around $20.5 \mathrm{ka}$ was likely driven by an acceleration in boreal summer insolation and that this occurred before any increase in atmospheric $\mathrm{CO}_{2}$, supporting an orbital forcing as the trigger for initial deglaciation (Clark et al., 2009; Gregoire et al., 2015b). This response of the ice sheet to atmospheric forcing also implies a higher sensitivity of land-terminating margins to small changes in climate forcing than had hitherto been recognised, although it should be noted that overall recession of the ice sheet was minimal (see Section 3.1). It is also interesting that whilst the southern margin was beginning to retreat, there is strong evidence that the margin in the far north-west was still advancing and likely attained its maximum position after $18.5 \mathrm{ka}$ (e.g. Murton et al., 2007; Kennedy et al., 2010; Lacelle et al., 2013). It is not clear why the northwest 
margin advanced to its maximum position a few millennia after the global LGM (sensu Clark et al., 2009), but Lacelle et al. (2013) suggested that sea-level rise and the opening of the Arctic Ocean along the Beaufort Sea coastline may have provided a local source of moisture and increased precipitation that enabled an advance of the LIS in this region. They also pointed out that the abundance of deformable sediments in the region may also have facilitated a rapid advance of the Mackenzie Lobe (ice stream) (cf. Beget, 1987).

Although increased atmospheric warming is thought to have triggered the initial retreat of the LIS, surface energy balance modelling suggests that the ice sheet's overall net surface mass balance remained positive for much of the early part of deglaciation (Ullman et al., 2015b). Ullman et al. (2015b) used a surface energy balance model forced by climate data from simulations with a fully coupled atmosphere-ocean General Climate Model (GCM) for key time slices during the last deglaciation $(24,21,19,16.5,15.5,14$, 13, 11.5 and $9 \mathrm{ka}$ ), see Fig. 11. They found that the net surface mass balance was positive until after $11.5 \mathrm{ka}$, which implied that mass loss was primarily driven by dynamic discharge via calving at marine-terminating ice streams (see Section 4.2). Only when summer temperatures increased by $6-7^{\circ} \mathrm{C}$ (relative to the gLGM) did the ice sheet's surface mass balance become increasingly negative in the early Holocene. This occurred between 11.5 and $9 \mathrm{ka}$ and was accompanied by an expansion of the ablation area that was previously restricted to the low-gradient lobe of the southern margin, but which expanded to most of the southern and western marginal areas by $9 \mathrm{ka}$ (Fig. 11). Ullman et al. (2015b) noted that this time period also saw the LIS lose most of its marine margin and would have coincided with a large reduction in dynamic discharge via calving losses (cf. Stokes et al., 2016).

It is worth noting, however, that the LIS had only lost around 40\% of area in $>10,000$ years of deglaciation from the LLGM to around $9 \mathrm{ka}$, despite increasing boreal insolation and a $~ 80$ ppm increase in $\mathrm{CO}_{2}$ (Ullman et al., 2015b). Thus, Ullman et al. (2015b) noted that the transition to a negative surface mass balance that occurred between $\sim 11.5$ and $9 \mathrm{ka}$, and the very rapid retreat of the ice sheet after $\sim 9 \mathrm{ka}$ (two to five times faster than before $\sim 11.5 \mathrm{ka}$ ), suggests that some kind of instability threshold was crossed and that the final deglaciation of $60 \%$ of the ice sheet's area was driven by surface melt, rather than dynamic discharge. This is supported by numerous studies that have shown that the rapid decay of the LIS in the early Holocene was driven by enhanced boreal summer insolation and increased ablation (Carlson et al., 2007; 2008; 2009a). For example, Carlson et al. (2009a) used a surface energy balance model, driven by atmosphere-ocean general circulation model at $9 \mathrm{ka}$, and calculated a net surface mass balance of $-0.67 \pm 0.13 \mathrm{~m} \mathrm{a}^{-1}$. Given volume estimates of the LIS at this time, it indicates that surface ablation accounted for $74 \pm 22 \%$ of mass loss at that time, with the remainder attributable to dynamic calving (Carlson et al., 2009a).

The evolving pattern of the surface mass balance of the ice sheet (e.g. Fig. 11) partly explains the clear asymmetry of retreat whereby the southern and western margins retreated much more rapidly than those in the north and especially the east. Following the initial retreat of the margins in the south, and the unzipping of the LIS and CIS in the east, surface-albedo feedbacks are likely to have helped drive further retreat (e.g. the emergence of darker land-surfaces). The formation of glacial lakes along the southern and western margins may also have enhanced localised calving and ice sheet draw-down 

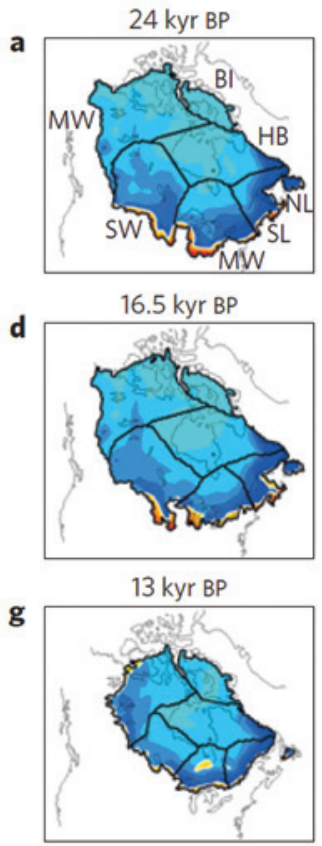

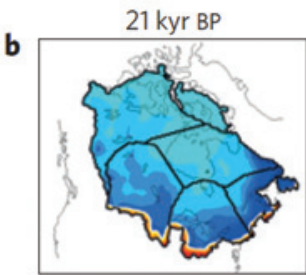

15.5 kyr BP

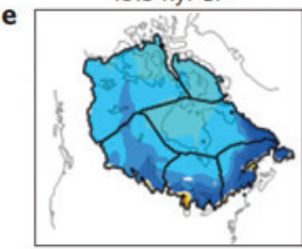

h

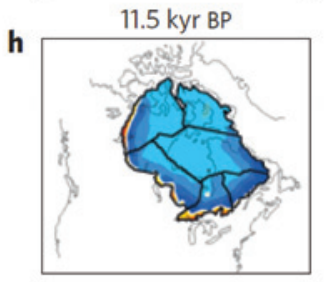

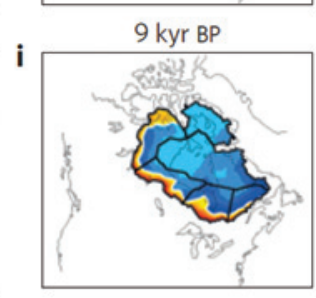

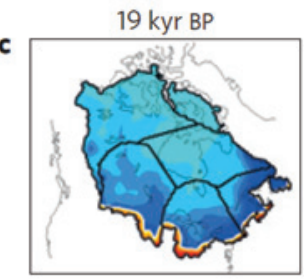

f

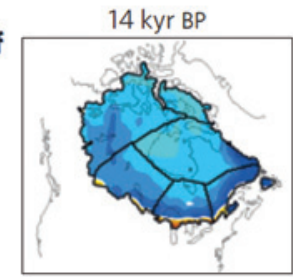

$$
\begin{array}{lllllll}
-10 & -8 & -6 & -4 & -2 & 0 & 1 \\
\mathrm{~m} \mathrm{yr}^{-1} & & & &
\end{array}
$$

Figure 11. Modelled surface mass balance of the Laurentide Ice Sheet at various time-slices, with black lines demarcating various sectors of the ice sheet: St Lawrence (SL), Midwestern (MW), Southwestern (SW), Northwestern (NW), Hudson Bay (HB), Banks Island (BI) and Newfoundland $(N L)$. Reprinted by permission from Macmillan Publishers Ltd: Nature Geoscience (Ullman et al., 2015b), copyright (2015).

(e.g. Andrews, 1973; Cutler et al., 2001; Stokes and Clark, 2004). Indeed, Andrews (1973) was one of the first to point out that the retreat of the LIS could not be explained solely by surface mass balance forcing and that an important process during deglaciation was mass loss associated with calving in both marine and lacustrine settings. However, Dyke and Prest (1987) noted that whilst calving was undoubtedly an important means of ice sheet ablation, its role should not be overemphasized. They pointed out that glacial lakes on the Prairies were small and that, until the formation of Lake Agassiz, calving cannot account for deglaciation for most of that region prior to its development. They also noted that the southern and eastern margins of the Labrador Sector had some of the longest marine margins, but that these margins retreated more slowly than the contemporaneous western margin of the Keewatin Sector, even though it occurred largely on dry land. It is also noteworthy that the marine-based part of the LIS over Hudson Bay and Foxe Basin were among the last to deglaciate, despite their susceptibility to calving and the fact that their central areas were isostatically-depressed hundreds of metres below sea level (Dyke and Prest, 1987). Indeed, even using an extreme 'calving instability', Marshall 
et al. (2000) were unable to evacuate a significant volume of ice from Hudson Strait in their modelling experiments, although more recent modelling (Bassis et al., 2017) suggests that this ice stream may have been particularly vulnerable to calving triggered by subsurface ocean warming (see Section 4.2).

A further explanation for the asymmetric retreat may also relate to the release and routing of meltwater during deglaciation and its subsequent impact on ocean circulation (Carlson et al., 2009b; Hoffman et al., 2012; Jennings et al., 2015; Gregoire et al., 2015b). Climate modelling indicates that meltwater discharge events routed into the Labrador Sea (e.g. from meltwater runoff and glacial lakes) could cause a cooling of up to $1.5^{\circ} \mathrm{C}$ over the Labrador Dome (Morrill et al., 2014), but with minimal cooling $\left(<0.5^{\circ} \mathrm{C}\right)$ along the western margin of the ice sheet, west of Hudson Bay. This negative feedback mechanism has thus been invoked to explain the relatively stability of the Labrador Dome, whilst the western margin of the ice sheet continued to retreat (Ullman et al., 2016).

\subsection{The role of ice streaming during deglaciation of the LIS}

Ice streams are the key drainage routes of an ice sheet (Bamber et al., 2000) and are known to exert a considerable influence on ice sheet configuration and mass balance (Nick et al., 2013; Ritz et al., 2015). It has been recognised for some time, therefore, that accurate reconstructions of the LIS require a detailed knowledge of the location of ice streams. The first use of the term 'ice stream' in relation to the LIS was by Bell (1895: p. 352-353), who inferred the presence of a "great ice stream" passing through Hudson Strait (see Brookes, 2007). However, it was not until 1981 that Denton and Hughes (1981) attempted to incorporate ice streams into a reconstruction of the entire LIS. They were the first to portray an extensive network of ice streams in the Northern Hemisphere ice sheets (Fig. 12a), which was clearly influenced by Hughes' knowledge of West Antarctic ice streams (e.g. Hughes, 1977). It is not clear what evidence was used to locate the ice streams, but several major ice streams were depicted in large topographic troughs, such as Hudson Strait, and others were depicted on low relief terrains where they appeared as a regularly-spaced network, perhaps hinting at some notion of spatial organisation. Dyke and Prest (1987) also incorporated ice stream flow-lines in their reconstruction of the LIS, some of which had earlier been recognised from erratic dispersal trains (Dyke et al., 1982; Dyke, 1984). Around that time, Dyke and Morris (1988) published a classic paper that would be one of the first to describe, in detail, the geomorphological 'footprint' of an ice stream on Prince of Wales Island in the Canadian Arctic Archipelago. They reported evidence for a convergent flow pattern of highly elongate drumlins associated with an erratic dispersal train with abrupt lateral margins.

Many of the lobes of the southern margin were also attracting attention as possible zones of ice streaming (Dredge and Cowan, 1989; Alley, 1991), largely because of their low surface slopes (Mathews, 1974) and earlier suppositions about the possibility of rapid flow in the form of surging (Wright, 1973; Clayton et al., 1985). Hicock and co-workers reported dispersal trains and tills associated with drumlins around the Great Lakes region that were interpreted to reflect ice streaming (Hicock, 1988, 1992; Hicock and Dreimanis, 1992). Later work by Patterson $(1997,1998)$ recognised entire landform assemblages that were 

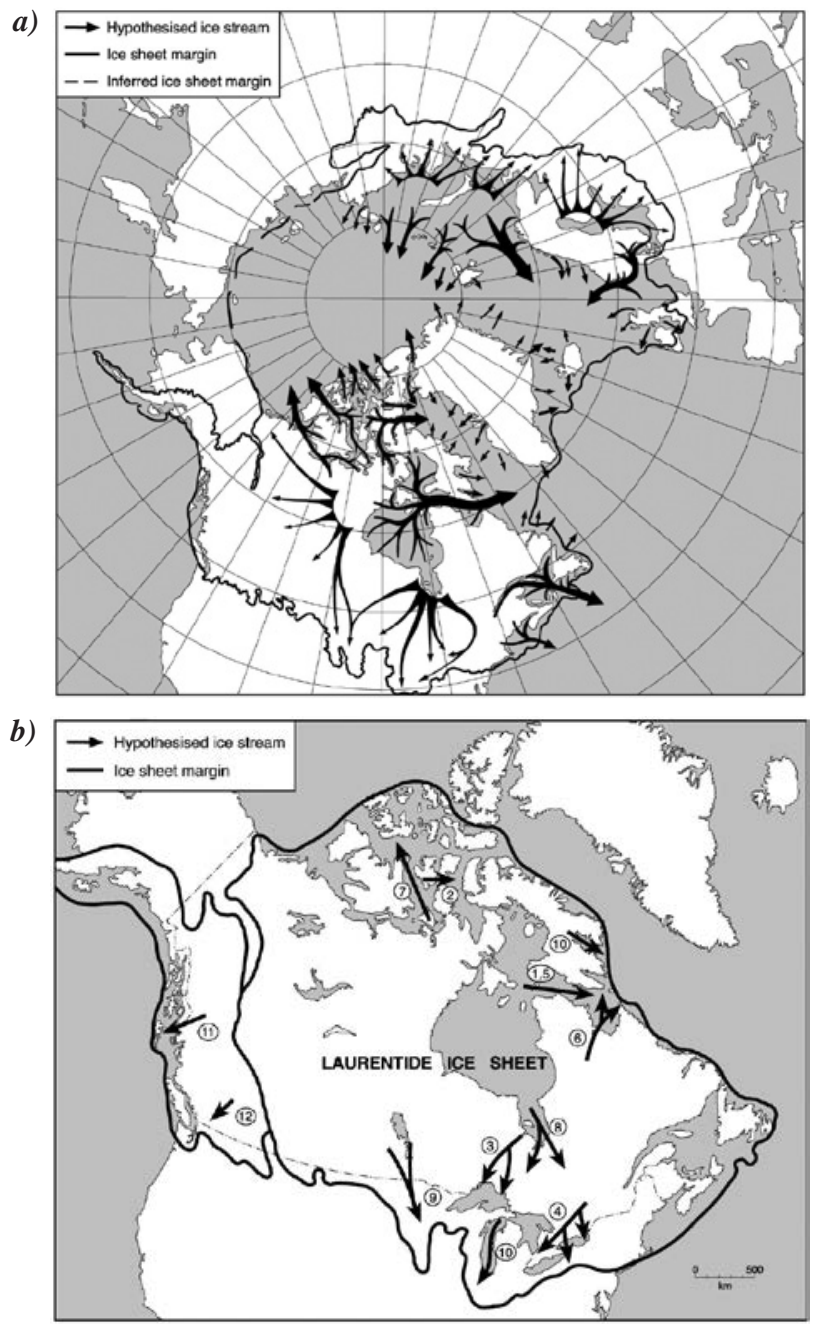

Figure 12. (a) Denton and Hughes' (1981) reconstruction of the Northern Hemisphere ice sheets at the global LGM with their hypothesised ice streams as black arrows. (b) Hypothesised ice streams based on a review of the literature from Stokes and Clark (2001). Compare with the latest inventory of 117 Laurentide ice streams shown in Figure 4.

interpreted to result from ice streaming and which included suites of level-to-streamlined fine-grained till, sometimes associated with highly elongate drumlins (Bluemle et al., 1993) that typically terminated towards the lobate margins, where thrusting of glacial sediment was evident in association with hummocky topography and major moraine systems. Similar, albeit much larger, patterns of streamlining were also reported by Clark (1993). Using Landsat satellite imagery, he identified a "hitherto undocumented and much larger form of ice moulded landscape" (p. 1) which comprised streamlined glacial lineations with typical lengths of between 8 and $70 \mathrm{~km}$, widths between 200 and $1300 \mathrm{~m}$, and spacings 
between 300 and $5 \mathrm{~km}$. Clark (1993) termed these features 'mega-scale glacial lineations' (MSGLs) and discussed a variety of possible origins, concluding that were likely to form under conditions of extremely rapid flow such as ice streams or surges.

Thus, by the late 1990s, significant progress had been made in terms of identifying the glacial geological evidence of ice streaming on the bed of the LIS. These studies suggested that ice streaming should leave behind sedimentological evidence of fast ice flow in the form of heavily deformed tills and distinctive erratic dispersal trains that often depicted convergent flow-patterns (e.g. Dyke and Morris, 1988; Hicock, 1988; Alley, 1991; Patterson, 1997, 1998). Many of these flow-patterns, or fans (cf. Kleman and Borgström, 1996), also contained highly elongate glacial lineations, which were postulated to reflect rapid ice velocities (e.g. Clark, 1993); and some were characterised by abrupt lateral margins (e.g. Hodgson, 1994) and lateral shear margin moraines (Dyke and Morris, 1988). Taken together, these were argued to represent the key 'geomorphological criteria' for identifying palaeo-ice streams, which Stokes and Clark (1999) formalised in a series of landsystems models depending on whether the ice stream terminated in water or on land, and whether the glacial lineations were formed rapidly and synchronously or slowly and time-transgressively.

Despite much progress, however, the first systematic literature review of ice streams in the LIS (Stokes and Clark, 2001) found only 10 hypothesised ice streams that had been identified based on unambiguous glacial geological evidence (Fig. 12b). However, a large number of ice streams were uncovered in the early 2000s (e.g. Clark and Stokes, 2001; Shaw, 2003), such that by 2004, a new map of ice streams in the LIS depicted a total of 49 ice streams, 34 of which had good evidence, with the remainder more uncertain (Winsborrow et al., 2004). Much of the evidence was based on the terrestrial glacial geological record, but the recognition of discrete layers of ice rafted debris (IRD) in North Atlantic sediment cores (Heinrich, 1988) had also begun to implicate episodic ice streaming, particularly in Hudson Strait, as being primarily responsible for their deposition (Bond et al., 1992; Andrews and Tedesco, 1992; MacAyeal, 1993; Marshall and Clark, 1997a, b; Andrews, 1998). In addition, the burgeoning growth of marine geophysical techniques saw a large number of ice stream footprints identified in offshore settings, particularly in Atlantic Canada (Shaw, 2003; Shaw et al., 2006; Todd et al., 2007; Shaw et al., 2009), but also in the Canadian Arctic Archipelago (MacLean et al., 2010) and in Hudson Bay (Ross et al., 2011). These techniques, allied with the growth of remote sensing studies across large regions of the ice sheet bed enabled a large number of ice streams to be identified (e.g. De Angelis and Kleman, 2005, 2007; Evans et al., 2008; Ross et al., 2009; Stokes et al., 2009; Ó Cofaigh et al., 2010).

Most recently, Margold et al. (2015a) compiled a new inventory of ice streams in the LIS based on an up-to-date review of the literature and systematic mapping from across the entire ice sheet bed using both terrestrial and offshore datasets. Their map (see Fig. 4) includes 117 ice streams and each ice stream is categorised according to the type of evidence it left behind, with an acknowledgement that some locations are more speculative than others. Indeed, identifying ice streams on more resistant 'hardbed' terrain, such as the Canadian Shield, is more difficult, but recent work (e.g. Eyles 
2012; Eyles and Putkinen, 2014; Krabbendam et al., 2016) has described rock drumlins, megaflutes and mega-lineated terrain, which likely represent a hard-bedded landform assemblage cut by ice streams. Thus, it is unlikely that any major ice streams are missing (Margold et al., 2015a, b). Indeed, most of the major ice streams are also captured in numerical modelling of the ice sheet, although the dynamics of land-terminating ice streams are much harder to reproduce (Stokes and Tarasov, 2010).

In a review of the spatial distribution of Laurentide ice streams, Margold et al. (2015b) noted that the pattern of ice streams (Fig. 4) during the LLGM resembled the present day velocity patterns in modern ice sheets (Fig. 13a). They estimated that around a third of the LIS margin perimeter was drained (intersected) by ice streams at the LLGM, which is a very similar value for the present-day Antarctic ice sheets. Large ice streams had extensive onset zones fed by multiple tributaries and, where ice drained through regions of high relief, the spacing of ice streams appears to show a degree of spatial self-organisation which was hinted at in the earlier work by Denton and Hughes (1981), but which has perhaps not been fully appreciated and explored. It is also clear that whilst topography exerted a primary control on fixing the location of ice many streams in the LIS, there were large areas along the western and southern margin of the ice sheet where networks of ice streams operated over soft sediments and switched direction repeatedly and probably over short (centennial) time scales (cf. Ó Cofaigh et al., 2000; Ross et al., 2009). As the ice sheet retreated on to its low relief interior, however, Margold et al. (2015a, b) noted that several ice streams showed no correspondence with topography or underlying geology, and were perhaps facilitated by localised build-up of pressurised subglacial meltwater (e.g. Stokes and Clark, 2003). Margold et al. (2015b) also highlighted that there have been very few attempts to date the initiation and cessation of the vast majority of ice streams, but that it is clear that they must have switched on and off during deglaciation, rather than maintaining the same trajectory as the ice margin retreated.

The extent to which changes in the ice stream drainage network were a cause or effect of ice sheet deglaciation is a key question. Put another way, does the drainage network of ice streams (Fig. 4) arise as a result of climatically-driven changes in ice sheet mass balance or could ice streams evolve to drive changes beyond that which might be expected from climate forcing alone? This question has rarely been addressed with respect to the LIS, but it is clear that ice streaming led to major reorganisations in the flow pattern of the ice sheet (Mooers et al., 1997; Veillette et al., 1999; Ó Cofaigh et al., 2000; Ross et al., 2009; Stokes et al., 2009). It is also clear that ice streaming is capable of rapidly lowering the ice sheet surface profile to lower elevations, where ablation will be increased (Robel and Tziperman, 2016). However, even where major reorganisations took place as a result of ice streaming, there is little evidence that deglaciation proceeded more rapidly. For example, if the Hudson Strait Ice Stream was responsible for major ice discharge events into the North Atlantic (e.g. Andrews and Tedesco, 1992; Andrews, 1998; Andrews and MacLean, 2003), there is tentative evidence for a reorganisation of the internal geometry and flow patterns of the ice sheet (Dyke and Prest, 1987; Mooers et al., 1997; Veillette et al., 1999; Dyke, 2004), but little evidence that these events resulted in a more rapid deglaciation of the area of the ice sheet, which was mostly linear through time (Fig. 9). The only exception to this is where individual outlet glaciers retreated through 

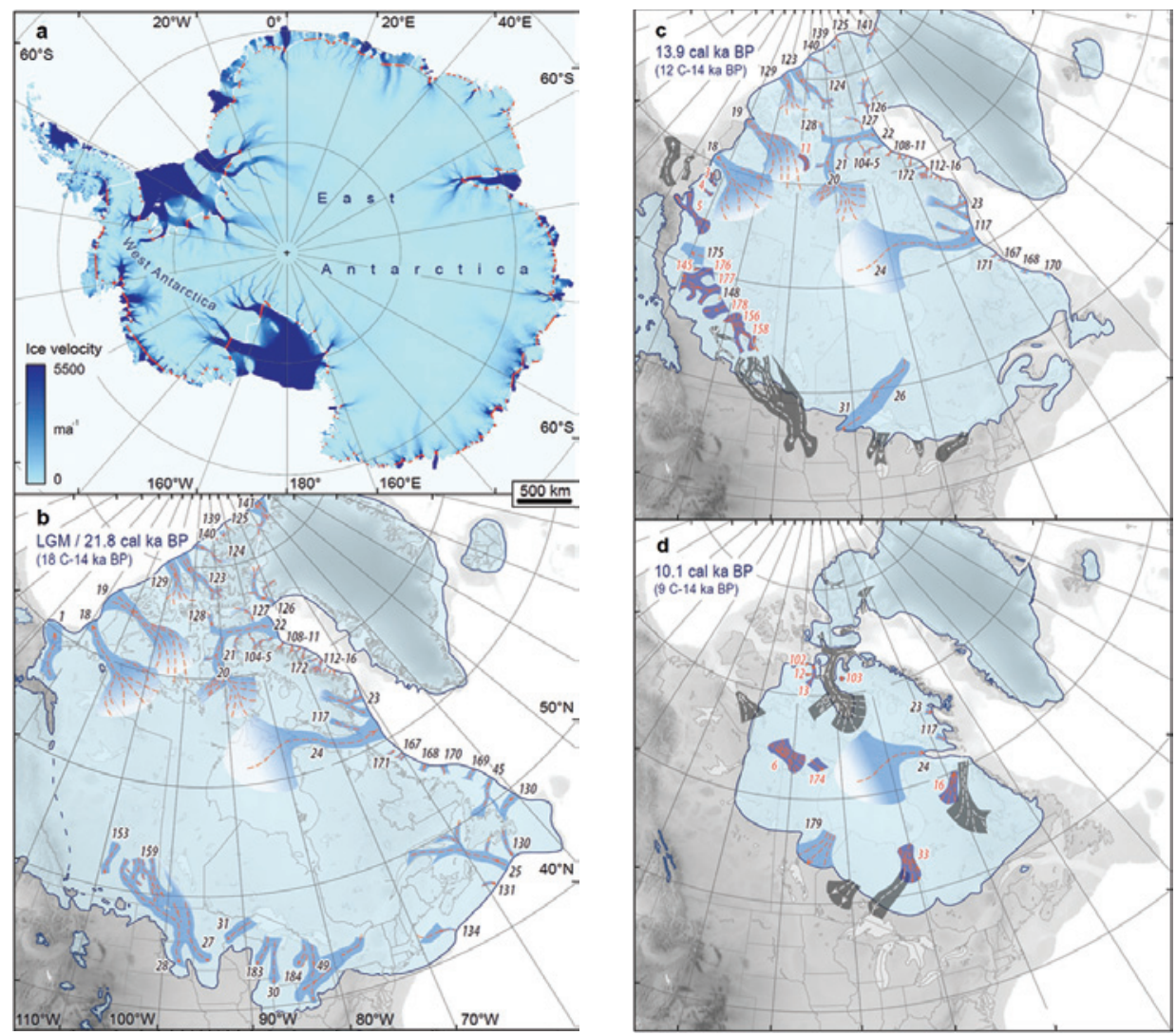

Figure 13. Ice flow velocity of the Antarctic ice sheet compared (at the same spatial scale) with reconstructions of ice stream activity in the LIS at selected time steps, from Stokes et al. (2016). (a) Present-day Antarctic ice sheet velocity, with red lines indicating where ice streams intersect the grounding line, which is a similar cumulative proportion ( 30\% of the perimeter) to the LIS in (b) (Margold et al., 2015b). (b, c, d) Ice streams reconstructed for the LIS at its LLGM (approximately $21.8 \mathrm{kyr}$ ago), $13.9 \mathrm{ka}$, and $10.1 \mathrm{ka}$. The locations of ice streams that were active at the given time are shown in blue and numbered in black. Those that switched off within the preceding $1 \mathrm{ka}$ are shown in grey and those that switched on during the subsequent $1 \mathrm{ka}$ are shown in dark blue with numbers in red. For cross-referencing, the numbers refer to the inventory numbers in Margold et al. $(2015 a, b)$. Reprinted by permission from MacMillan Publishers Ltd: Nature (Stokes et al., 2016), copyright (2016).

deep troughs that resulted in a localised acceleration in retreat until the margin was able to re-stabilise on higher ground (Briner et al., 2009). It is also possible that eustatic sea-level rise early in deglaciation may have increased water depths close to marine-terminating ice streams, enhancing their discharge and leading to rapid draw-down of ice. As noted above, this might partly explain the relatively early deglaciation of the Atlantic provinces, where deglaciation was associated with a margin in deep water (Andrews, 1973; Mosher et al., 1989; Piper et al., 1990; King, 1996; Scnitker et al., 2001; Shaw et al., 2006), but it appears to have had less effect at the marine margin in the Canadian Arctic Archipelago. 
In a recent study, Stokes et al. (2016) examined whether the cumulative impact of ice streams was able to increase and sustain rates of mass loss during deglaciation of the LIS beyond those that might be expected from climate forcing alone. They used the Dyke et al. (2003) ice margin chronology to bracket the duration of the 117 ice streams in the inventory from Margold et al. (2015a: see Fig. 4). They found that as the ice sheet retreated, ice streams activated and deactivated in different locations (see Fig. 13) and, unsurprisingly, their overall number decreased. Perhaps more surprising was that ice streams occupied a progressively smaller percentage of the ice sheet perimeter during deglaciation. At its maximum, approximately $27 \%$ of the LIS margin was streaming, but this value decreased to between $25 \%$ and $20 \%$ from $16 \mathrm{ka}$ to $13 \mathrm{ka}$, and then rapidly dropped to $\sim 5 \%$ at $11 \mathrm{ka}$ (Stokes et al., 2016). This implies that the final 4 to $5 \mathrm{ka}$ of deglaciation was largely driven by surface melt, which is corroborated surface mass balance modelling (see Section 4.1) and inferences based on the density of subglacial meltwater conduits (eskers) (Storrar et al., 2014). Stokes et al. (2016) also used a simple scaling relationship based on the width and discharge of modern ice streams to estimate the potential cumulative discharge from Laurentide ice streams through time, and found that this decreased and was strongly scaled to the ice sheet's volume. This scaling is also found in numerically modelled estimates of ice stream discharge (Stokes et al., 2012). They concluded that whilst the underlying geology and topography clearly influenced ice stream activity (cf. Marshall et al., 1996), the drainage network of ice streams - at the ice sheet scale - appears to have adjusted in response to ice sheet volume. Thus, contrary to the view that sees ice streams as unstable entities that can accelerate icesheet deglaciation, Stokes et al. (2016) found that ice streams exerted progressively less influence on deglaciation of the LIS.

This is not to say, however, that ice streams did not play any role in deglaciation. They were likely to be very important in reducing the volume (if not the area) of the ice sheet in early deglaciation, when large parts of the LIS had a marine margin (Andrews, 1973), which is known to be a key control on ice streaming (Winsborrow et al., 2010). Tanner (1965) was one of the first to recognise the importance of glacial isostatic depression in generating relatively higher sea levels at the marine margin when the ice sheet was at near-maximum configurations. This would have increased calving losses and encouraged ice stream draw-down. More recently, numerical modelling has shown that a simple feedback between ocean forcing and isostatic adjustment can explain the observed magnitude and timing of Heinrich events from the Hudson Strait Ice Stream (Bassis et al., 2017). Bassis et al. (2017) showed that when the LIS is at its near-maximum extent, the terminus of the ice stream remains grounded on bed topography depressed about $300 \mathrm{~m}$ below sea level, rendering it particularly vulnerable to sub-surface ocean warming. They argued that a small warming in the subsurface ocean is enough to trigger rapid retreat of the ice sheets into the over-deepened bed (generating a Heinrich event) and that retreat continues until isostatic adjustment allows the bed to uplift, isolating the terminus from ocean forcing. At this point, they noted that retreat ceases and, with the ice sheet at its minimum extent, bed uplift facilitates regrowth on a slower timescale than collapse.

Other numerical modelling experiments suggest that ice streaming may render large ice sheet more sensitive to Milankovitch forcing (Marshall and Clark, 2002; Robel and 
Tziperman, 2016). Large ice sheets are likely to have a larger proportion of their bed above the pressure melting point and this is a first order control on the likelihood of generating ice streams (MacAyeal, 1993; Marshall and Clarke, 1997a, b; Stokes et al., 2012; Marshall and Clark, 200; Tarasov et al., 2012; Robel and Tziperman, 2016). In their numerical modelling experiments, Robel and Tziperman (2016) found that when ice streams are sufficiently developed, an upward shift in the ELA caused by external climatic (Milankovitch) forcing results in rapid deglaciation. However, when the same shift in the ELA was applied to an ice sheet without fully-formed ice streams, it led to continued ice sheet growth or slower deglaciation. These idealised experiments were also repeated using key aspects of the climatic and geographic complexity of the LIS and generated similar results: enhanced discharge caused by ice stream acceleration is the primary source of mass loss during the early part of deglaciation in response to orbital forcing. An interesting corollary is that these processes also explain why Milankovitch forcing late in a 100 ka glacial cycle leads to full deglaciation, when the ice sheet is large, isostatically-depressed, and has developed numerous large ice streams; while the same forcing does not produce deglaciation early in the glacial cycle when the ice sheet is small and without ice streams (Marshall and Clark, 2002; Abe-Ouchi et al., 2013; Robel and Tziperman, 2016).

\section{Conclusions and Outlook}

The LIS is thought to have initiated from an ice-free state over North America during MIS 5d, around 116-114 ka (e.g. Marshall et al., 2000; Stokes et al., 2012). It grew rapidly from its initial inception over the Arctic/sub-Arctic plateaux along the eastern seaboard of Canada and likely attained an MIS 4 maximum around 65-60 ka (Marshall et al., 2000; Stokes et al., 2012). Its extent during MIS 3 is uncertain (Dredge and Thorleifson, 1987; Stokes et al., 2012; Dalton et al., 2016), but it grew rapidly to its Local Last Glacial Maximum, which was attained around 26-25 ka (e.g. Dyke, 2002; Clark et al., 2009), although with some regions advancing much later, such as in the far north-west (Lacelle et al., 2013). After over a century of debate, a consensus has emerged that it existed as an extensive, multi-domed ice sheet that extended to the edge of the continental shelf at its marine margins, but that it was thinner $(\sim 3000 \mathrm{~m})$ than some earlier work had suggested and consumed a sea-level equivalent of around $50 \mathrm{~m}$ (Clark et al., 1996). It is thought that it existed at or close to this maximal configuration for several thousand years (Dyke et al., 2002).

Our understanding of the pattern and timing of deglaciation is due in no small part to several major syntheses that have remained benchmark reconstructions for several decades (e.g. Bryson et al., 1969; Denton and Hughes, 1981; Boulton et al., 1995; Dyke and Prest, 1987; Dyke, 2004), augmented by numerical modelling, which has seen rapid developments over the last two decades (Marshall et al., 1996; Marshall et al., 2000; Tarasov et al., 2012; Peltier et al., 2015, Gregoire et al., 2015b). This body of work shows a clear asymmetry in retreat whereby the western and southern margins retreated back towards the major dispersal centres over Foxe Basin-Baffin Island and QuebecLabrador. Ice margin retreat was relatively slow prior to $\sim 17 \mathrm{ka}$, but it is clear that the ice sheet volume was decreasing. Between around 16 and $13 \mathrm{ka}$, however, the margin 
retreated rapidly, particularly along the southern and western margins, which led to the separation of the Laurentide from the Cordilleran Ice Sheet. In contrast, the northern and eastern margins of the ice sheet underwent only minimal recession (e.g. Dyke and Prest, 1987; Dyke, 2004). During the Younger Dryas, the overall net recession was reduced and several notable readvances are known to have taken place (e.g. Dyke and Savelle, 2000; Jennings et al., 1996; Andrews et al., 1998). Following the Younger Dryas, the ice sheet retreated two to five times faster than previous rates (Ullman et al., 2015b). Recession of the northern and eastern margins accompanied the continued rapid recession of the southern and western margins, although a series of moraine systems were built in some locations, which likely indicate temporary stabilisations (Dyke, 2004) or surges/ice streaming (Stokes and Clark, 2003). Final deglaciation of the remnant Keewatin and Foxe Domes (Dyke, 2004; Ross et al., 2012; Simon et al., 2014), left a remnant Labrador Dome that is thought to have deglaciated by around $6.7 \mathrm{ka}$ (e.g. Ullman et al., 2016).

The pattern and timing of deglaciation of the LIS represents a valuable analogue for understanding the rates and mechanisms of ice sheet deglaciation (Denton and Hughes, 1981; Kleman and Applegate, 2014; Margold et al., 2015b; Stokes et al., 2016), which may be relevant to assessments of the future stability of modern-day ice sheets. In this context, it is generally accepted that the initial trigger for deglaciation was an increase in boreal summer insolation (Clark et al., 2009; Ullman et al., 2015a). However, modelling of the ice sheet's net surface mass balance indicates that it remained positive until around $11 \mathrm{ka}$ (Ullman et al., 2015b). This suggests that the predominant source of mass loss was initially via rapidly-flowing ice streams, particularly at the ice sheet's marine margins (Andrews, 1973; Shaw et al., 2006; De Angelis and Kleman, 2007; Stokes et al., 2016). Indeed, our understanding of palaeo-ice streams has grown from almost completely ignorance in the early 1980 s to the latest inventory of 117 ice streams that operated at various times during deglaciation (Margold et al., 2015a, b). Only when summer temperatures increased by $6-7^{\circ} \mathrm{C}$ relative to the LLGM did the ice sheet's surface mass balance become increasingly negative in the early Holocene (around 11.5 to $9 \mathrm{ka}$ ). Thereafter, deglaciation of the remaining $60 \%$ of the ice sheet's initial area was accomplished mostly by surface melt (Dyke, 2004; Carlson et al., 2007, 2008, 2009a). This implies that 'dynamic discharge' via ice streams exerted progressively less influence on the deglaciation of the LIS (Stokes et al., 2016).

In his most recent synthesis, Dyke (2004) noted that the improved age control and more detailed mapping of deglacial patterns over the last few decades have enabled improved reconstructions of the LIS and a closer correlation between the deglaciation sequence and major climatic events recognised in the North Atlantic region and in the Greenland ice core record. That said, there remain areas of the ice sheet where deglaciation is relatively poorly constrained. The western margin of the LIS (and western interior) has emerged as a key area for a number of important debates, including the concept of an ice-free corridor and the peopling of North America (Dyke, 2004; Dixon, 2013; Pedersen et al., 2016). The possibility of a rapid saddle-collapse and a large meltwater pulse (and sea-level jump) have also implicated this region (Gregoire et al., 2012, 2015a), which has also been identified as a drainage route for a putative outburst flood from Glacial Lake Agassiz (Tarasov and Peltier, 2005; Murton et al., 2010; Fisher and Lowell, 2012). It is 
interesting to note that, with admirable foresight, this region was specifically highlighted almost 50 years ago by Bryson et al. (1969: p. 5) who stated that "it is unfortunate that there are so few available dates from the western interior; the corridor between the Cordillera and the retreating ice front is of great interest to the anthropologist, biologist, and climatologist". It is perhaps more unfortunate that, almost five decades on, the scarcity of dates from this region persists, and this is a key area for future research to address. Improvements in the ice margin chronology and the quantification of its uncertainties will also provide tighter constraints for numerical modelling of the ice sheet, which will also require improvements in terms of model resolution and in the representation of the key physics, such as the simulation of ice streams, subglacial processes and changes in meltwater drainage routes (Marshall et al., 2000; Hindmarsh, 2009; Stokes et al., 2015; Kirchner et al., 2016; Wickert, 2016). This should help resolve important debates about the role of the LIS during major reorganisations of the ocean-climate system (Broecker et al., 1989; Bond et al., 1992; Barber et al., 1999; Carlson and Clark, 2012), and enable improved predictions of the response of modern-day ice sheets to future climate change.

\section{Acknowledgements}

The writing of this paper was made considerably easier (and even more enjoyable) as a result of the remarkable quality and meticulous nature of previous reconstructions of the LIS and major review papers, most notably involving John Andrews, Art Dyke, Terry Hughes, Jack Ives, and Vic Prest. I would like to thank Martin Margold for discussions and comments on an earlier version of this manuscript, and my colleagues David Evans and Colm Ó Cofaigh for sharing their wealth of knowledge and expertise on the glacial history of this ice sheet. I am also grateful to John Andrews and an anonymous reviewer for their encouraging comments during the peer review process and to David Palacios for inviting me to contribute to this special issue. My interest in the LIS was ignited in undergraduate lectures by Chris Clark, under whose tutelage I also conducted my Ph.D. I am grateful for his guidance and infectious enthusiasm about this giant amongst the 'Last Great Ice Sheets'. I would also like to acknowledge Chris Orton, Department of Geography, Durham University, who re-drew many of the Figures for this paper.

\section{References}

Abe-Ouchi, A., Saito, F., Kawamura, K., raymo, M.E., Okuno, J., Takahashi, K., Blatter, H. 2013. Insolation-driven 100,000-year glacial cycles and hysteresis of ice-sheet volume. Nature 500, 190-194. http://doi.org/10.1038/nature12374.

Abe-Ouchi, A., Saito, F., Kageyama, M., Braconnot, P., Harrison, S.P., Lambexk, K., Otto-Bliesner, B.L., Peltier, W.R., Tarasov, L., Peterschmitt, J-Y., Takahashi, K. 2015. Ice-configuration in the CMIP5/PMIP3 Last Glacial Maximum experiments. Geoscientific Model Development 8 , 3621-3637. http://doi.org/10.5194/gmd-8-3621-2015.

Allard, G., Roy, M., Ghaleb, B., Richard, P.J.H., Larouche, A.C., Veillette, J.J., Parent, M. 2012. Constraining the age of the last interglacial-glacial transition in the Hudson Bay lowlands (Canada) using U-Th dating of buried wood. Quaternary Geochronology 7, 37-47. http://doi. org/10.1016/j.quageo.2011.09.004. 
Alley, R.B. 1991. Deforming-bed origin for southern Laurentide till sheets? Journal of Glaciology 37 (125), 67-76. http://doi.org/10.1017/S0022143000042817.

Alley, R.B., Blankenship, D.D., Bentley, C.R., Rooney, S.T. 1986. Deformation of till beneath ice stream B, West Antarctica. Nature 322, 57-59. http://doi.org/10.1038/322057a0.

Alley, R.B., Mayewski, P.A., Sowers, T., Stuiver, M., Taylor, K.C., Clark, P.U. 1997. Holocene climatic instability: a prominent, widespread event 8200 yr ago. Geology 25, 483-486. http:// doi.org/10.1130/0091-7613(1997)025<0483:HCIAPW>2.3.CO;2.

Amos, C.L., Knoll, R. 1987. The Quaternary sediments of Banquereau, Scotian Shelf. Geological Society of America Bulletin 99, 244-260. http://doi.org/10.1130/0016-7606(1987)99<244:TQ SOBS $>2.0 . \mathrm{CO} 2 ; 2$.

Amos, C.L., Miller, A.A.L. 1990. The Quaternary stratigraphy of southwest Sable Island Bank, eastern Canada. Geological Society of America Bulletin 102, 915-934. http://doi. org/10.1130/0016-7606(1990)102<0915:TQSOSS>2.3.CO;2.

Andrews, J. T. 1969. The pattern and interpretation of restrained, post-glacial and residual rebound in the area of Hudson Bay. In: P.J. Hood (Ed.), Earth Science Symposium on Hudson Bay. Geological Survey of Canada Paper 68-53, p. 49.

Andrews, J.T. 1973. The Wisconsin Laurentide Ice Sheet: dispersal centres, problems of rates of retreat, and climatic implications. Arctic and Alpine Research 5 (3), 185-199.

Andrews, J.T. 1998. Abrupt changes (Heinrich events) in late Quaternary North Atlantic marine environments: a history and review of data and concepts. Journal of Quaternary Science 13 (1), 3-16.

Andrews, J.T. 2006. The Laurentide Ice Sheet: a review of history and processes. In: P.G. Knight (Ed.), Glacier Science and Environmental Change. Blackwell Publishing, UK, pp. 201-207.

Andrews, J.T., Mahaffy, M.A. 1976. Growth rates of the Laurentide Ice Sheet and sea level lowering (with emphasis on the 115,000 B.P. sea level low). Quaternary Research 6, 167-183.

Andrews, J.T., Miller, G.H. 1972. Quaternary history of northern Cumberland Peninsula, Baffin Island, N.W.T., Canada. Part IV: maps of present glaciation limits and lowest equilibrium line altitude for north and south Baffin Island. Arctic and Alpine Research 4, 45-59.

Andrews, J.T., Tedesco, K. 1992. Detrital carbonate-rich sediments, northwestern Labrador Sea: implications for ice-sheet dynamics and iceberg rafting (Heinrich) events in the North Atlantic. Geology 20 (12), 1087-1090. http://doi.org/10.1130/0091-7613(1992)020<1087DCRSNL $>2.3 . C O ; 2$.

Andrews, J.T., MacLean, B. 2003. Hudson Strait ice streams: a review of stratigraphy, chronology and links with North Atlantic Heinrich events. Boreas 32, 4-17. http://doi. org/10.1080/03009480310001010.

Andrews, J.T., Kirby, M.E., Jennings, A.E., Barber, D.C. 1998. Late Quaternary stratigraphy, chronology, and depositional processes on the SE Baffin Island slope, detrital carbonate and Heinrich events: implications for onshore glacial history. Géographie Physique et Quaternaire 52, 91-105.

Andrews, J.T., Jennings, A.E., MacLean, B. 2001. Late Quaternary stratigraphy of Hatton and Resolution basins, east of Hudson Strait. In: B. MacLean (Ed.), Marine Geology of Hudson Strait and Ungava Bay, Eastern Arctic Canada: Late Quaternary Sediments, Depositional Environments, and Late Glacial-Deglacial History Derived from Marine and Terrestrial Studies. Geological Survey of Canada Bulletin 566, 57-64.

Anonymous 1970. Last throes of Laurentide Ice Sheet. Nature 225 (5229), 224.

Argus, D.F., Peltier, W.R. 2010. Constraining models of postglacial rebound using space geodesy: a detailed assessment ofmodel ICE-5G (VM2) and its relatives. Geophysical Journal International 181, 697-723. http://doi.org/10.1111/j.1365-246X.2010.04562.x. 
Bamber, J.L., Vaughan, D.G., Joughin, I. 2000. Widespread complex flow in the interior of the Antarctic Ice Sheet. Science 287 (5456), 1248-1250. http://doi.org/10.1126/ science.287.5456.1248.

Barber, D.C., Dyke, A., Hillaire-Marcel, C., Jennings, A.E., Andrews, J.T., Kerwin, M.W., Bilodeau, G., McNeely, R., Southon, J., Morehead, M.D., Gagnon, J.-M. 1999. Forcing of the cold event of 8,200 years ago by catastrophic drainage of Laurentide lakes. Nature 400, 344-348. http://doi.org/10.1038/22504.

Barnett, P.J. 1992. Quaternary geology of Ontario. In: P.C. Thurston, H.R. Williams, R.H. Sutcliffe, G.M. Scott (Eds.), Geology of Ontario. Toronto, Ontario Geological Survey, Special Volume 4, 1011-1088.

Bassis, J.N., Petersen, S.V., Cathles, L.M. 2017. Heinrich events triggered by ocean forcing and modulated by isostatic adjustment. Nature 542,332-334. http://doi.org/10.1038/nature21069.

Beierle, B., Smith, D.G., 1998. Severe drought in the early Holocene (10,000-6800 BP) interpreted from lake sediment cores, southwestern Alberta. Palaeogeography, Palaeoclimatology, Palaeoecology 140, 75-83. http://doi.org/10.1016/S0031-0182(98)00044-3.

Beget, J. 1987. Low profile of the northwest Laurentide map sheets. Arctic and Alpine Research $19,81-87$.

Bell, R. 1884. Observations on geology, minerology, zoology and botany of the Labrador coast, Hudson's Strait and Bay. Canada, Geological Survey, Report of Progress, 1882-83-84, Part DD.

Bell, R. 1895. The Labrador Peninsula. Scottish Geographical Magazine 11 (7), 335-361.

Blake Jr., W. 1970. Studies of glacial history in arctic Canada. I. Pumice, radiocarbon dates, and differential postglacial uplift in the eastern Queen Elizabeth Islands. Canadian Journal of Earth Sciences 7, 634-664.

Blake Jr., W. 1992. Shell-bearing till along Smith Sound, Ellesmere Island-Greenland: age and significance. Sveriges Geologiska Undersoekning, Series Ca 81, 51-58.

Blake Jr., W. 1993. Holocene emergence along the Ellesmere Island coasts of northernmost Baffin Bay. Norsk Geologisk Tiddsskrift 73, 147-160.

Bluemle, J.P., Lord, L.M., Hunke, N.T. 1993. Exceptionally long, narrow drumlins formed in subglacial cavities, North Dakota. Boreas 22, 15-24.

Bond, G., Heinrich, H., Broecker, W., Labeyrie, L., Mcmanus, J., Andrews, J., Huon, S., Jantschik, R., Clasen, S., Simet, C., Tedesco, K., Klas, M., Bonani, G., Ivy, S. 1992. Evidence for massive discharges of icebergs into the North-Atlantic ocean during the last glacial period. Nature 360 (6401), 245-249.

Bond, G., Showers, W., Cheseby, M., Lotti, R., Almasi, P., deMenocal, P., Priore, P., Cullen, H., Hajda, I., Bonani, G. 1997. A pervasive millennial-scale cycle in North Atlantic Holocene and glacial climates. Science 278, 1257-1266. http://doi.org/10.1126/science.278.5341.1257.

Bonifay, D., Piper, D.J.W., 1988. Probable Late Wisconsinan ice margin on the upper continental slope off St. Pierre Bank, eastern Canada. Canadian Journal of Earth Sciences 25, 853-865.

Boulton, G.S., Hindmarsh, R.C.A. 1987. Sediment deformation beneath glaciers: Rheology and glaciological consequences. Journal of Geophysical Research 92, 9059-9082.

Boulton, G.S., Clark, C.D. 1990a. A highly mobile Laurentide Ice Sheet revealed by satellite images of glacial lineations. Nature 346, 813e817.

Boulton, G.S., Clark, C.D. 1990b. The Laurentide Ice Sheet through the last glacial cycle - the topology of drift lineations as a key to the dynamic behaviour of former ice sheets. Transactions of the Royal Society of Edinburgh - Earth Sciences 81, 327-347.

Boulton, G.S., Smith, G.D., Jones, A.S., Newsome, J. 1985. Glacial geology and glaciology of the last mid-latitude ice sheets. Journal of the Geological Society of London 142, 4467-474. 
Briner, J.P., Miller, G.H., Davis, P.T., Finkel, R.C. 2006. Cosmogenic radionuclides from fjord landscapes support differential erosion by overriding ice sheets. Geological Society of America Bulletin 118, 406-420. http://doi.org/10.1130/B25716.1.

Briner, J.P., Bini, A.C., Anderson, R.S. 2009. Rapid early Holocene retreat of a Laurentide outlet glacier through an Arctic fjord. Nature Geoscience 2, 496-499. http://doi.org/10.1038/ngeo556.

Broecker, W.S., Kennett, J., Flower, B., Teller, J., Trumbore, S., Bonani, G., Wolfli, W. 1989. Routing of meltwater from the Laurentide Ice Sheet during the Younger Dryas cold episode. Nature 341, 318-321. http://doi.org/10.1038/341318a0.

Brookes, I.A., 2007. First recognition of a Laurentide Ice Stream: Robert Bell on Hudson Strait. Géographie Physique et Quaternaire 61 (2-3), 211-216.

Bryson, R.A., Wendland, W.M., Ives, J.D., Andrews, J.T. 1969. Radiocarbon ischrones on the disintegration of the Laurentide Ice Sheet. Arctic and Alpine Research 1 (1), 1-13.

Budd, W.F., Smith, I.N. 1981. The growth and retreat of ice sheets in response to orbital radiation changes. In: I. Allison (Ed.), Sea level, Ice, and Climatic Change, International Association of Hydrological Sciences Publication 131, 369-409.

Carlson, A.E., Winsor, K. 2012. Northern Hemisphere ice-sheet response to past climate warming. Nature Geoscience 5, 607-613. http://doi.org/10.1038/ngeo1528.

Carlson, A.E., Clark, P.U. 2012. Ice sheet sources of sea level rise and freshwater discharge during the last deglaciation. Reviews of Geophysics 50 (4), 4007-4072. http://doi. org/10.1029/2011RG000371.

Carlson, A.E., Clark, P.U., Raisbeck, G.M., Brook, E.J., 2007. Rapid Holocene deglaciation of the Labrador sector of the Laurentide ice sheet. Journal of Climate 20, 5126-5133. http://doi. org/10.1175/JCLI4273.1.

Carlson, A.E., LeGrande, A.N., Oppo, D.W., Came, R.E., Schmidt, G.A., Anslow, F.S., Licciardi, J.M., Obbink, E.A. 2008. Rapid early Holocene deglaciation of the Laurentide Ice Sheet. Nature Geoscience 1, 620-624. http://doi.org/10.1038/ngeo285.

Carlson, A.E., Anslow, F.S., Obbink, E.A., LeGrande, A.N., Ullman, D.J., Licciardi, J.M. 2009a. Surface-melt driven Laurentide Ice Sheet retreat during the early Holocene. Geophysical Research Letters 36, L24502. http://doi.org/10.1029/2009GL040948.

Carlson, A.E., Clark, P.U., Haley, B.A., Klinkhammer, G.P. 2009b. Routing of western Canadian Plains runoff during the 8.2 ka cold event. Geophysical Research Letters 36, L14704. http:// doi.org/10.1029/2009GL038778.

Catto, N.R., Liverman, D.G.E., Bobrowsky, P.T., Rutter, N.W. 1996. Laurentide, Cordilleran, and Montane glaciation in the western Peace River-Grande Prairie region, Alberta and British Columbia. Quaternary International 32, 21-32. http://doi.org/10.1016/10406182(95)00061-5.

Chamberlin, T.C. 1913. Map of North America during the great ice age. Rand McNally \& Co., Chicago. 57 x 40 inches. Scale: 1 inch $=104$ miles. Colored.

Clark, C.D. 1993. Mega-scale glacial lineations and cross-cutting ice-flow landforms. Earth Surface Processes and Landforms 18 (1), 1-29.

Clark, C.D., Stokes, C.R. 2001. Extent and basal characteristics of the M'Clintock Channel Ice Stream. Quaternary International 86 (1), 81-101. http://doi.org/10.1016/S10406182(01)00052-0.

Clark, P.U., Josenhans, H.W. 1990. Reconstructed ice-flow patterns and ice limits using drift pebble lithology, outer Nachvak Fiord, northern Labrador: discussion. Canadian Journal of Earth Sciences 27, 1002-1006.

Clark, P.U., Clague, J.J., Currey, B.B., Dreimanis, A., Hicock, S.R., Miller, G.H., Berger, G.W., Eyles, N., Lamothe, M., Miller, B.B., Mott, R.J., Oldale, R.N., Stea, R.R., Szabo, J.P., Thorleifson, 
L.H., Vincent, J.-S. 1993. Initiation and development of the Laurentide and Cordilleran ice sheets following the last interglaciation. Quaternary Science Reviews 12 (2), 79-114.

Clark, P.U., Licciardi, J.M., MacAyeal, D.R., Jenson, J.W. 1996. Numerical reconstruction of a soft-bedded Laurentide Ice Sheet during the last glacial maximum. Geology 24 (8), 679-682.

Clark, P.U., Marshall, S.J., Clarke, G.K.C., Hostetler, S.W., Licciardi, J.M., Teller, J.T. 2001. Freshwater forcing of abrupt climate change during the last glaciation. Science 293, 283-287. http://doi.org/10.1126/science.1062517.

Clark, P.U., Dyke, A.S., Shakun, J.D., Carlson, A.E., Clark, J., Wohlfarth, B., Mitrovica, J.X., Hostetler, S.W., McCabe, A. 2009. The Last Glacial Maximum. Science 325, 710-714. http:// doi.org/10.1126/science.1172873.

Clayton, L., Moran, S.R. 1982. Chronology of Late Wisconsin glaciation in middle North America. Quaternary Science Reviews 1, 55-82.

Clayton, L., Teller, J. T., Attig, J. W. 1985. Surging of the southwestern part of the Laurentide Ice Sheet. Boreas 14, 235-241.

CLIMAP Project Members 1976. The surface of ice-age earth. Science 191 (4232), 1131-1137.

Coleman, A.P. 1920. Extent and thickness of the Labrador Ice Sheet. Geological Society of America, Bulletin 31, 319-328.

Colleoni, F., Wekerle, C., Näslund, J-O., Brandefelt, J., Masina, S. 2016. Constraint on the penultimate glacial maximum Northern Hemisphere ice topography $(\approx 140 \mathrm{kyrs} B P$ ). Quaternary Science Reviews 137, 97-112. http://doi.org/10.1016/j.quascirev.2016.01.024.

Condron, A., Winsor, P. 2012. Meltwater routing and the Younger Dryas. PNAS 109 (49), 1992819933. http://doi.org/10.1073/pnas.1207381109.

Cutler, K.B., Edwards, R.L., Taylor, F.W., Cheng, H., Adkins, J., Gallup, C.D., Cutler, P.M., Burr, G.S., Bloomo, A.L. 2003. Rapid sea-level fall and deep-ocean temperature change since the last interglacial period. Earth and Planetary Science Letters 206, 253-271. http://doi. org/10.1016/S0012-821X(02)01107-X.

Cutler, P.I., Mickelson, D.M., Colgan, P.M., MacAyeal, D.R., Parizek, B.R. 2001. Influence of the Great Lakes on the dynamics of the southern Laurentide Ice sheet: numerical experiments. Geology 29 (11), 1039-1042. http://doi.org/10.1130/0091-7613(2001)028<1039:IOGTLO>2.0.CO;2.

Dalton, A.S., Finkelstein, S.A., Barnett, P.J., Forman, S.L. 2016. Constraining the Late Pleistocene history of the Laurentide Ice Sheet by dating the Missinaibi Formation, Hudson Bay Lowlands, Canada. Quaternary Science Reviews 146, 288-299. http://doi.org/10.1016/j. quascirev.2016.06.015.

Daly, R.A. 1902. The geology of the northeast coast of Labrador. Harvard University Museum of Comparative Zoology Bulletin 38, 205-270.

DeAngelis,H.,Kleman, J. 2005. Palaeo-ice streams in the northern Keewatin sector of the Laurentide ice sheet. Annals of Glaciology 42, 135-144. http://doi.org/10.3189/172756405781812925.

De Angelis, H., Kleman, J. 2007. Palaeo-ice streams in the Foxe/Baffin sector of the Laurentide Ice Sheet. Quaternary Science Reviews 26 (9-10), 1313-1331. http://doi.org/10.1016/j. quascirev.2007.02.010.

Denton, G.H., Hughes, T. 1981. The Last Great Ice Sheets. Wiley-Interscience, New York, 484 pp.

Deschamps, P., Durand, N., Bard, E., Hamelin, B., Camoin, G., Thomas, A.L., Henderson, G.M. Okuno, J., Yokoyama, Y. 2012. Ice-sheet collapse and sea-level rise at the Bølling warming 14,600 years ago. Nature 483, 559-564. http://doi.org/10.1038/nature10902.

Dixon, E.J. 2013. Late Pleistocene colonization of North America from Northeast Asia: new insights from large-scale paleogeographic reconstructions. Quaternary International 285, 57-67. http://doi.org/10.1016/j.quaint.2011.02.027.

Donn, W. L., Farrand, W. R., Ewing, M. 1962. Pleistocene ice volumes and sea-level lowering. Journal of Geology 70, 206-214. 
Dredge, L.A., Thorleifson, L.H. 1987. The Middle Wisconsinan history of the Laurentide Ice Sheet. Géographie Physique et Quaternaire 41 (2), 215-235.

Dredge, L.A., Cowan, W.R. 1989. Quaternary geology of the southwestern Canadian Shield. In: R.J. Fulton (Ed.), Quaternary Geology of Canada and Greenland. Geological Survey of Canada, Ottawa, pp. 214-235.

Dutton, A., Carlson, A.E., Long, A.J., Milne, G.A., Clark, P.U., DeConto, R., Horton, B.P., Rahmstorf, S., Raymo, M.E. 2015. Sea-level rise due to polar ice-sheet mass loss during past warm periods. Science 349, p. 153. http://doi.org/10.1126/science.aaa4019.

Dyke, A.S. 1984. Quaternary geology of Boothia Peninsula and northern District of Keewatin, central Canadian Arctic. Geological Survey of Canada Memoir 407, 26 pp.

Dyke, A.S. 1999. The last glacial maximum of Devon Island, Arctic Canada: support for an Innuitian Ice Sheet. Quaternary Science Reviews 18, 393-420. http://doi.org/10.1016/S02773791(98)00005-5.

Dyke, A.S. 2004. An outline of North American deglaciation with emphasis on central and northern Canada. In: J. Ehlers, P.L. Gibbard (Eds.), Quaternary Glaciations-extent and Chronology, Part II. Elsevier Science and Technology Books, Amsterdam, pp. 371-406.

Dyke, A.S., Prest, V.K. 1987. Late Wisconsinan and Holocene history of the Laurentide Ice Sheet. Géographie Physique et Quaternaire 41 (2), 237-263.

Dyke, A.S., Morris, T.F. 1988. Canadian landform examples. 7. Drumlin fields, dispersal trains, and ice streams in Arctic Canada. Canadian Geographer 32 (1), 86-90.

Dyke, A.S., Savelle, J.M. 2000. Major end moraines of Younger Dryas age on Wollaston Peninsula, Victoria Island, Canadian Arctic: implications for paleoclimate and for formation of hummocky moraine. Canadian Journal of Earth Sciences 37, 601-619. http://doi.org/10.1139/e99-118.

Dyke, A.S., Dredge, L.A., Vincent, J.-S. 1982. Configuration and dynamics of the Laurentide Ice Sheet during the Late Wisconsin maximum. Géographie Physique et Quaternaire 36 (1-2), 5-14.

Dyke, A.S., Andrews, J.T., Clark, P.U., England, J.H., Miller, G.H., Shaw, J., Veillette, J.J., 2002. The Laurentide and Innutian ice sheets during the Last Glacial Maximum. Quaternary Science Reviews 21, 9-31. http://doi.org/10.1016/S0277-3791(01)00095-6.

Dyke, A.S., Moore, A., Robertson, L. 2003. Deglaciation of North America. Geological Survey of Canada Open File 1574.

England, J.H. 1976a. Postglacial isobases and uplift curves from the Canadian and Greenland High Arctic. Arctic and Alpine Research 8 (1), 61-78.

England, J.H. 1976b. Late Quaternary glaciation of the eastern Queen Elizabeth Islands, N.W.T, Canada: Alternative models. Quaternary Research 6, 185-202.

England, J.H. 1999. Coalescent Greenland and Innuitian ice during the last glacial maximum: revising the quaternary of the Canadian high arctic. Quaternary Science Reviews 18, 421456. http://doi.org/10.1016/S0277-3791(98)00070-5.

England, J.H., Smith, I.R., Evans, D.J.A. 2000. The last glaciation of east-central Ellesmere Island, Nunavut: ice dynamics, deglacial chronology, and sea level change. Canadian Journal of Earth Sciences 37, 1355-1371. http://doi.org/10.1139/e00-060.

England,J.H., Furze, M.F.A., Doupé, J.P. 2009. Revision of the NW Laurentide Ice Sheet: implications for paleoclimate, the northeast extremity of Beringia, and Arctic Ocean sedimentation. Quaternary Science Reviews 28, 1573-1596. http://doi.org/10.1016/j.quascirev.2009.04.006.

Eriksson, A., Betti, L., Friend, A.D., Lycett, S.J., Singarayer, J.S., von Cramon-Taubadel, N., Valdes, P.J., Balloux, F., Manica, A. 2012. Late Pleistocene climate change and the global expansion of anatomically modern humans. PNAS 109, 16089-16094. http://doi.org/10.1073/ pnas.1209494109.

Evans, D.J.A., Clark, C.D., Rea, B.R. 2008. Landform and sediment imprints of fast glacier flow in the southwest Laurentide Ice Sheet. Journal of Quaternary Science 23 (3), 249-272. http:// doi.org/10.1002/jqs.1141. 
Eyles, N. 2012. Rock drumlins and megaflutes of the Niagara Escarpment, Ontario, Canada: a hard bed landform assemblage cut by the Saginaw-Huron Ice Stream. Quaternary Science Reviews 55, 34-49. http://doi.org/10.1016/j.quascirev.2012.09.001.

Eyles, N., Putkinen, N. 2014. Glacially-megalineated limestone terrain of Anticosti Island, Gulf of St. Lawrence, Canada; onset zone of the Laurentian Channel Ice Stream. Quaternary Science Reviews 88, 125-134. http://doi.org/10.1016/j.quascirev.2014.01.015.

Falconer, G., Ives, J.D., Løken, O.H., Andrews, J.T. 1965. Major end moraines in eastern and central Arctic Canada. Geographical Bulletin 7 (2), 137-153.

Fisher, D.A., Reeh, N., Langley, K. 1985. Objective reconstructions of the Late Wisconsinan Laurentide Ice Sheet and the significance of deformable beds. Géographie Physique et Quaternaire 39 (3), 229-238.

Fisher, T.G., Smith, D.G. 1994. Glacial Lake Agassiz: its northwest maximum extent in Saskatchewan (Emerson phase). Quaternary Science Reviews 13, 845-858. http://doi. org/10.1016/0277-3791(94)90005-1.

Fisher, T.G., Lowell, T.V. 2012. Testing northwest drainage from Lake Agassiz using extant ice margin and strandline data. Quaternary International 260, 106-114. http://doi.org/10.1016/j. quaint.2011.09.018.

Fisher, T.G., Smith, D.G., Andrews, J.T. 2002. Preboreal oscillation caused by a glacial Lake Agassiz flood. Quaternary Science Reviews 21, 873-878. http://doi.org/10.1016/S02773791(01)00148-2.

Flint, R.F. 1943. Growth of the North American Ice Sheet during the Wisconsin Age. Geological Society of America, Bulletin 54, 352-362.

Flint, R.F. 1947. Glacial Geology and the Pleistocene Epoch. John Wiley, New York.

Flint, R.F. 1971. Glacial and Quaternary Geology. John Wiley, New York.

Flint, R.F., Demorest, M., Washburn, A.L. 1942. Glaciation of the Shickshock Mountains, Gaspé, Peninsula. Geological Society of America, Bulletin 53, 1211-1230.

Flint, R.F., et al., 1945. Glacial Map of North America. Geological Society of America, Special Paper 60.

Forbes, D.L., Boyd, R., Shaw, J. 1991. Late Quaternary sedimentation and sea-level changes on the inner Scotian Shelf. Continental Shelf Research 11, 1155-1179.

Fulton, R.J. 1989. Quaternary Geology of Canada and Greenland. Geological Survey of Canada, Geology of Canada, No. 1,839 pp.

Gipp, M.R. 1994. Late Wisconsinan glaciation of Emerald Basin, Nova Scotia. Canadian Journal of Earth Sciences 31, 554-566.

Gipp, M.R., Piper, D.J.W. 1989. Chronology of Late Wisconsinan glaciation, Emerald Basin, Scotian Shelf. Canadian Journal of Earth Sciences 26, 333-335.

Goebel, T., Waters, M.R., O'Rourke, D.H. 2008. The Late Pleistocene dispersal of modern humans in the Americas. Science 319, 1497-1502. http://doi.org/10.1126/science.115.3569.

Gosse, J., Grant, D.R., Klein, J., Lawn, B. 1995. Cosmogenic ${ }^{10} \mathrm{Be}$ and ${ }^{26} \mathrm{Al}$ constraints on weathering zone genesis, ice cap basal conditions, and Long Range Mountain Newfoundland) glacial history. Programme, Abstracts, Field Guides, CANQUA CGRG Joint Meeting, St. John's, CA19.

Gowan, E.J. 2013. An assessment of the minimum timing of ice free conditions of the western Laurentied Ice Sheet.Quaternary Science Reviews 75, 100-113.http://doi.org/10.1016/j.quascirev.2013.06.001 .

Gregoire, L.J., Payne, A.J., Valdes, P.J. 2012. Deglacial rapid sea level rises caused by ice sheet saddle collapses. Nature 487, 219-222. http://doi.org/10.1038/nature11257.

Gregoire, L.J., Otto-Bliesner, B., Valdes, P.J., Ivanovic, R. 2015a. Abrupt Bølling warming and ice saddle collapse contributions to the Meltwater Pulse 1a rapid sea level rise. Geophysical Research Letters 43, 9130-9137. http://doi.org/10.1002/2016GL070356.

Gregoire, L.J., Valdes, P.J., Payne, A.J. 2015b. The relative contribution of orbital forcing and greenhouse gases to the North American deglaciation. Geophysical Research Letters 42, http://doi.org/10.1002/2015GL066005. 
Hardy, L. 1982. Le Wisconsinien supérieur à l'est de la baie James (Québec). Naturaliste Canadien 109, 333-351.

Harington, C.R. 1989. Pleistocene vertebrate localities in the Yukon. In: L.D. Carter,T.D. Hamilton, J.P. Galloway (Eds.), Late Cenozoic History of the Interior Basins of Alaska and the Yukon. United States Geological Survey Circular, 1026, pp. 93-98.

Heinrich, H. 1988. Origin and consequences of cyclic ice rafting in the Northeast Atlantic Ocean during the past 130,000 years. Quaternary Research 29 (2), 142-152. http://doi. org/10.1016/0033-5894(88)90057-9.

Hemming, S.R. 2004. Heinrich events: massive late Pleistocene detritus layers of the North Atlantic and their global climate imprint. Reviews of Geophysics 42, RG1005. http://doi. org/10.1029/2003RG000128.

Hicock, S.R. 1988. Calcareous till facies north of Lake Superior, Ontario: implications for Laurentide ice streaming. Géographie Physique et Quaternaire 42 (2), 120-135.

Hicock, S.R. 1992. Global interactions and rheologic superposition in subglacial till near Bradtville, Ontario, Canada. Boreas 21 (1), 73-88.

Hicock, S.R., Dreimanis, A. 1992. Deformation till in the Great Lakes region: implications for rapid flow along the south-centralmargin of the Laurentide Ice Sheet. Canadian Journal of Earth Sciences 29 (7), 1565-1579.

Hindmarsh, R.C.A. 2009. Consistent generation of ice streams via thermos-viscous instabilities modulated by membrane stresses. Geophysical Research Letters 36, L06502. http://doi.org/ 10.1029/2008GL036877.

Hodgson, D.A. 1994. Episodic ice streams and ice shelves during retreat of the northwesternmost sector of the late Wisconsinan Laurentide Ice Sheet over the central Canadian Arctic Archipelago. Boreas 23 (1), 14-28.

Hoffman, J.S., Carlson, A.E., Winsor, K., Klinkhammer, G.P., LeGrande, A.N., Andrews, J.T., Strasser, J.C. 2012. Linking the $8.2 \mathrm{ka}$ event and its freshwater forcing in the Labrador Sea. Geophysical Research Letters 39, L18703. http://doi.org/10.1002/grl.50111.

Hughes, T. 1977. West Antarctic ice streams. Reviews of Geophysics 15 (1), 1-46.

Hughes, T., Denton, G.H., Grosswald, M.G. 1977. Was there a late-Wiirm Arctic ice sheet? Nature 266, 596-602. doi:10.1038/266596a0.

Hughes, P. D., Gibbard, P. L., Ehlers, J. 2013. Timing of glaciation during the last glacial cycle: Evaluating the concept of a global 'Last Glacial Maximum' (LGM). Earth-Science Reviews 125, 171-198. http://doi.org/10.1016/j.earscirev.2013.07.003.

IPCC 2013. Summary for Policymakers. In: T.F. Stocker, D. Qin, G.-K. Plattner, M. Tignor, S.K. Allen, J. Boschung, A. Nauels, Y. Xia, V. Bex, P.M. Midgley (Eds.), Climate Change 2013: The Physical Science Basis. Contribution of Working Group I to the Fifth Assessment Report of the Intergovernmental Panel on Climate Change. Cambridge University Press, Cambridge, United Kingdom and New York, NY, USA.

Ives, J.D. 1957. Glaciation of the Torngat mountains, Northern Labrador. Arctic 10, 67-87.

Ives, J.D. 1978. The maximum extent of the Laurentide Ice Sheet along the East Coast of North America during the Last Glaciation. Arctic 31 (1), 24-53.

Ives, J.D., Andrews, J.T., Barry, R.G. 1975. Growth and decay of the Laurentide Ice Sheet and comparisons with Fenno-Scandinavia. Die Naturwissenschaften 62, 118-125.

Jennings, A.E. 1993. The Quaternary history of Cumberland Sound, southeast Baffin Island: the marine evidence. Géographie Physique et Quaternaire 47, 21-42.

Jennings, A.E., Tedesco, K.A., Andrews, J.T., Kirby, M.E. 1996. Shelf erosion and glacial ice proximity in the Labrador Sea during and after Heinrich events (H-3 or 4 to H-0) as shown by foraminifera. In: J.T. Andrews, W.E.N. Austin, H. Bergstrom, A.E. Jennings (Eds.), Palaeoceanography of the North Atlantic Margins. Geological Society Special Publication No. 111, 29-49. 
Jennings, A.E., Andrews, A., Pearce, C., Wilson, L., Ólfasdótttir, S. 2015. Detrital carbonate peaks on the Labrador shelf, a 13-7 ka template for freshwater forcing from the Hudson Strait outlet of the Laurentide Ice Sheet into the subpolar gyre. Quaternary Science Reviews 107, 62-80. http://doi.org/10.1016/j.quascirev.2014.10.022.

Josenhans, H.W., Zevenhuizen, J. 1990. Dynamics of the Laurentide Ice Sheet in Hudson Bay, Canada. Marine Geology 92, 1-26.

Josenhans, H., Lehman, S. 1999. Quaternary stratigraphy and glacial history of the Gulf of St. Lawrence, Canada. Canadian Journal of Earth Sciences 36, 1327-1345. http://doi. org/10.1139/e99-030.

Kaplan, M.R. 1999. The last glaciation of the Cumberland Sound region, Baffin Island, Canada, based on glacial geology, cosmogenic dating, and numerical modeling. Unpublished Ph.D. Thesis, University of Colorado, Boulder, $206 \mathrm{pp}$.

Karrow, P.F., Calkin, P.E. 1985. Quaternary evolution of the Great Lakes. Geological Association of Canada Special Paper 30, 258 pp.

Kennedy, K.E., Froese, D.G., Zazula, G.D., Lauriol, B. 2010. Last Glacial Maximum age for the northwest Laurentide maximum from the Eagle River spillway and delta complex, northern Yukon. Quaternary Science Reviews 29, 1288-1300. http://doi.org/10.1016/j.quascirev.2010.02.015.

King, L.H. 1996. Late Wisconsinan ice retreat from the Scotian Shelf. Geological Society of America Bulletin 108, 1056-1067.

Kirby, M.E., Andrews, J.T. 1999. Mid-Wisconsinan Laurentide Ice Sheet growth and decay: implications for Heinrich events 3 and 4. Paleoceanography 14 (2), 211-223.

Kirchner, N., Ahlkrona, J., Gowan, E.J., Lötstedt, P., Lea, J.M., Noormets, R., von Sydow, L., Dowdeswell, J.A., Benham, T. 2016. Shallow ice approximation, second order shallow ice approximation, and full Stokes models: A discussion of their roles in palaeo-ice sheet modelling and development. Quaternary Science Reviews 147, 136-147. http://doi. org/10.1016/j.quascirev.2016.01.013.

Kleman, J., Borgström, I. 1996. Reconstruction of palaeo-ice sheets: the use of geomorphological data. Earth Surface Processes and Landforms 21 (10), 893-909.

Kleman, J., Applegate, P.J. 2014. Durations and propagation patterns of ice sheet instability events. Quaternary Science Reviews 92, 32-39. http://doi.org/10.1016/j.quascirev.2013.07.030.

Kleman, J., Fastook, J., Stroeven, A. 2002. Geologically and geomorphologically constrained numerical model of Laurentide Ice Sheet inception and build-up. Quaternary International 95-96, 87-98. http://doi.org/10.1016/S1040-6182(02)00030-7.

Kleman, J., Jansson, K., De Angelis, H., Stroeven, A.P., Hattestrand, C., Alm, G., Glasser, N.F. 2010. North American Ice Sheet build-up during the last glacial cycle, 115-21 kyr. Quaternary Science Reviews 29, 17-18. http://doi.org/10.1016/j.quascirev.2010.04.021.

Koerner, R.M. 1980. Instantaneous glacierization, the rate of albedo change, and feedback effects at the beginning of an Ice Age. Quaternary Research 13, 153-159. http://doi.org/10.1016/00335894(80)90025-3.

Krabbendam, M., Eyles, N., Putkinen, N., Bradwell, T., Arbelaez-Moreno, L. 2016. Streamlined hard beds formed by palaeo-ice streams: a review. Sedimentary Geology 338, 24-50. http:// doi.org/10.1016/j.sedgeo.2015.12.007.

Lacelle, D., Lauroil, B., Zazula, G., Ghaleb, B., Utting, N., Clark, I.D. 2013. Timing of advance and basal condition of the Laurentide Ice Sheet during the last glacial maximum in the Richardson Mountains, NWT. Quaternary Research 80, 274-283. http://doi.org/10.1016/j.yqres.2013.06.001.

Lakeman, T. R., England, J. H. 2012. Palaeo-glaciological insights from the age and morphology of the Jesse moraine belt, western Canadian Arctic. Quaternary Science Reviews 47, 82-100. http://doi.org/10.1016/j.quascirev.2012.04.018. 
Lakeman, T. R., England, J. H. 2013. Late Wisconsinan glaciation and postglacial relative sealevel change on western Banks Island, Canadian Arctic Archipelago. Quaternary Research 80, 99-112. http://doi.org/10.1016/yqres.2013.02.001.

Lambeck, K., Rouby, H., Purcell, A., Sun, Y., Sambridge, M. 2014. Sea level and global ice volumes from the last glacial maximum to the Holocene. PNAS 111, 15296-15303. http:// doi.org/10.1073/pnas.1411762111.

Lambeck, K., Purcell, A., Zhao, S. 2017. The North American Late Wisconsin ice sheet and mantle viscosity from glacial rebound analyses. Quaternary Science Reviews 158, 172-210. http:// doi.org/10.1016/j.quascirev.2016.11.033.

Lambert, A., Courtier, N., James, T.S. 2006. Long-term monitoring by absolute gravimetry: tides to postglacial rebound. Journal of Geodynamics 41, 307-317. http://doi.org/10.1016/ jog.2005.08.032.

Lamoureux, S.F., England, J.H. 2000. Late Wisconsinan glaciation of the central sector of the Canadian High Arctic. Quaternary Research 54, 182-188. http://doi.org/10.1016/ qres.2000.2167.

Licciardi, J.M., Clark, P.U., Jenson, J.W., MacAyeal, D.R. 1998. Deglaciation of a soft-bedded Laurentide Ice Sheet. Quaternary Science Reviews 17, 427-448. http://doi.org/10.1016/ S0277-3791(97)00044-9.

Lowe, J.J., Ammann, B., Birks, H.H., Bjorck, S., Coope, G.R., Cwynar, L. Beaulieu, J-L., Mott, R.J., Peteet, D.M., Walker, M.J.C. 1994. Climatic changes in areas adjacent to the North Atlantic during the last glacial-interglacial transition (14-9 ka BP): a contribution to IGCP253. Journal of Quaternary Science 9, 185-198. http://doi.org/10.1002/jqs.3390090215.

Løken, O.H. 1966. Baffin Island refugia older than 54,000 years. Science 153, 1378-1380.

MacAyeal, D. 1993. Binge/purge oscillations of the Laurentide ice sheet as a cause of the North Atlantic's Heinrich events. Paleoceanography 8 (6), 775-784.

MacLean, B., Blasco, S., Bennett, R., England, J., Rainey, W., Hughes-Clarke, J., Beaudoin, J. 2010. Ice keel seabed features in marine channels of the central Canadian Arctic Archipelago: evidence for former ice streams and iceberg scouring. Quaternary Science Reviews 29, 2280-2301. http://doi.org/10.1016/j.quascirev.2010.05.032.

Margold, M., Stokes, C.R., Clark, C.D., Kleman, J. 2015a. Ice streams in the Laurentide Ice Sheet: a new mapping inventory. Journal of Maps 11 (3), 380-395. http://doi.org/10.1080/174456 47.2014.912036.

Margold,M.,Stokes,C.R., Clark,C.D. 2015b. Ice streams in the Laurentide Ice Sheet: identification, characteristics and comparison to modern ice sheets. Earth-Science Reviews 143, 117-146. http://doi.org/10.1016/j.earscirev.2015.01.011.

Marcott, S.A., Shakun, J.D., Clark, P.U., Mix, A.C. 2013. A reconstruction of regional and global temperature for the past 11,300 years. Science 339, 1198-1201. http://doi.org/10.1126/ science. 1228026 .

Marsella, K.A., Bierman, P.R., Davis, P.T., Caffee, M.W. 2000. Cosmogenic ${ }^{10} \mathrm{Be}$ and ${ }^{26} \mathrm{Al}$ ages for the last glacial maximum, eastern Baffin Island, Arctic Canada. Geological Society of America Bulletin 112, 1296-1312.

Marshall, S.J., Clarke, G.K.C., 1997a. A continuum mixture model of ice stream thermomechanics in the Laurentide Ice Sheet. 1. Theory. Journal of Geophyical Research Solid Earth 102 (B9), 20599-20613.

Marshall, S.J., Clarke, G.K.C. 1997b. A continuum mixture model of ice stream thermomechanics in the Laurentide Ice Sheet.2. Application to the Hudson Strait Ice Stream. Journal of Geophysical Research Solid Earth 102 (B9), 20615-20637.

Marshall, S.J. 2002. Modelled nucleation centres of the Pleistocene ice sheets from an ice sheet model with subgrid parameterizations. Quaternary International 95-96, 125-137. http://doi. org/10.1016/S1040-6182(02)00033-2. 
Marshall, S.J., Clark, P.U. 2002. Basal temperature evolution of North American ice sheets and implications for the 100-kyr cycle. Geophysical Research Letters 29 (4), 2214. http://doi. org/10.1029/2002GL015192.

Marshall, S.J., Clarke, G.K.C., Dyke, A.S., Fisher, D.A. 1996. Geologic and topographic controls on fast flow in the Laurentide and Cordilleran Ice Sheets. Journal of Geophysical Research Solid Earth 101 (B8), 17827-17839. http://doi.org/10.1029/96JB01180.

Marshall, S.J., Tarasov, L., Clarke, G.K.C., Peltier, W.R. 2000. Glaciological reconstruction of the Laurentide Ice Sheet: physical processes and modelling challenges. Canadian Journal of Earth Sciences 37 (5), 769-793. http://doi.org/10.1139/e99-113.

Mathews, W. H. 1974. Surface profiles of the Laurentide Ice Sheet in its marginal areas. Journal of Glaciology 13, 37-43.

Mayewski, P.A., Denton, G.H., Hughes, T.J. 1981. Late Wisconsin ice sheets of North America. In: G.H. Denton, T. Hughes (Eds.), The Last Great Ice Sheets. Wiley-Interscience, New York, pp. 67-178.

Mazzotti, S., Lambert, A., Henton, J., James, T.S., Courtier, N. 2011. Absolute gravity calibration of GPS velocities and glacial isostatic adjustment in mid-continent North America. Geophysical Research Letters 38. http://doi.org/10.1029/2011GL049846.

Miller, A.A.L., Fader, G.B.J., Moran, K. 2001. Late Wisconsinan ice advances, ice extent, and glacial regimes interpreted from seismic data, sediment physical properties, and foraminifera: Halibut Channel, Grand Banks of Newfoundland. In: T.K. Weddle, M.J. Retelle (Eds.), Deglacial History and Relative Sea-Level Changes, Northern New England and Adjacent Canada. Geological Society of America Special Paper 351, 51-107.

Miller, G.H., Dyke, A.S. 1974. Proposed extent of late Wisconsin ice on Baffin Island. Geology 2, 125-130.

Miller, G.H., Kaufman, D.S. 1990. Rapid fluctuations of the Laurentide Ice Sheet at the mouth of Hudson Strait: new evidence for ocean/ice-sheet interactions as a control on the Younger Dryas. Paleoceanography 5, 907-919.

Miller, G.H., Wolfe, A.P., Steig, E.J., Sauer, P.E., Kaplan, M.R., Briner, J.P. 2002. The Goldilocks dilemma: big ice, little ice, or "just right" ice in the Eastern Canadian Arctic. Quaternary Science Reviews 21,33-48. http://doi.org/10.1016/S0277-3791(01)00085-3.

Mooers, H.D., Lehr, J.D. 1997. Terrestrial record of Laurentide Ice Sheet reorganization during Heinrich events. Geology 25 (11), 987-990.

Morrill, C., Ward, E.M., Wagner, A.J., Otto-Bliesner, B.L., Rosenbloom, N. 2014. Large sensitivity to freshwater forcing location in 8.2 ka simulations. Paleoceanography 29, 930-945. http:// doi.org/10.1002/2014PA002669.

Mosher, D.C., Piper, D.J.W., Vilks, G.V., Aksu,A.E., Fader, G.B.J. 1989. Evidence for Wisconsinan glaciations in the Verrill Canyon area, Scotian Slope. Quaternary Research 31, 27-40. http:// doi.org/10.1016/0033-5894(89)90083-5.

Murton, J.B., Frenchen, M., Maddy, D. 2007. Luminescence dating of mid- to Late Wisconsinan aeolian sand as a constraint on the last advance of the Laurentide Ice Sheet across the Tuktoyaktuk coastlands, western Arctic Canada. Canadian Journal of Earth Sciences 44, 857-869. http://doi.org/10.1139/e07-015.

Murton, J.B., Bateman, M.D., Dallimore, S.R., Teller, J.T., Yang, Z. 2010. Identification of Younger Dryas outburst flood path from Lake Agassiz to the Arctic Ocean. Nature 464, 740743. http://doi.org/10.1038/nature08954.

Murton, J.B, Bateman, M.D, Waller, R.I., Whiteman, C.A. 2015. Late Wisconsin glaciation of Hadwen and Summer islands, Tuktoyaktuk Coastlands, NWT, Canada. In: GEOQuébec2015: 7th Canadian Permafrost Conference, 20-23 September, 2015, Quebec City, Canada.

Nicholl, J.A.L., Hodell, D.A., Naafs, B.D.A., Hillaire-Marcel, C., Channell, J.E.T., Romero, O.E. 2012. A Laurentide outburst flooding event during the last interglacial period. Nature Geoscience 5 (12), 901-904. http://doi.org/10.1038/ngeo1622. 
Nick, F.M., Vieli, A., Anderson, M.L., Joughin, I., Payne, A., Edwards, T.J., Pattyn, F., van de Wal, R.S.W. 2013. Future sea-level rise from Greenland's main outlet glaciers in a warming climate. Nature 497, 235-238. http://doi.org/10.1038/nature12068.

Nixon, F. C., England, J. H. 2014. Expanded Late Wisconsinan ice cap and ice sheet margins in the western Queen Elizabeth Islands, Arctic Canada. Quaternary Science Reviews 91, 146-164. http://doi.org/10.1016/j.quascirev.2013.10.036.

Occhietti, S., Parent, M., Lajeunesse, P., Robert, F., Govare, E. 2011. Late Pleistocene-early Holocene decay of the Laurentide ice sheet in Quebec-Labrador. In: J. Ehlers, P.L. Gibbard, P.D. Hughes (Eds.), Quaternary Glaciations - Extent and Chronology, vol. 15. Elsevier Science and Technology Books, Amsterdam, pp. 601-630.

Odell, N.E. 1933. The mountains of northern Labrador. Geographical Journal, 82 (3-4), 193-211.

Ó Cofaigh, C., England, J., Zreda, M. 2000. Late Wisconsinan glaciation of southern Eureka Sound: evidence for extensive Innuitian ice in the Canadian high arctic during the last glacial maximum. Quaternary Science Reviews 19, 1319-1341. http://doi.org/10.1016/S02773791(99)00104-3.

Ó Cofaigh, C., Evans, D.J.A., Smith, I.R. 2010. Large-scale reorganization and sedimentation of terrestrial ice streams during late Wisconsinan Laurentide Ice Sheet deglaciation. Geological Society of America Bulletin 122 (5-6), 743-756. http://doi.org/10.1130/26476.1.

Patterson, C.J. 1997. Southern Laurentide ice lobes were created by ice streams: Des Moines lobe in Minnesota, USA. Sedimentary Geology 111, 249-261 . http://doi.org/10.1016/S00370739(97)00018-3.

Patterson, C.J. 1998. Laurentide glacial landscapes: the role of ice streams. Geology, 26, 643-646.

Paterson, W.S.B. 1972. Laurentide Ice Sheet: estimated volumes during Late Wisconsin. Reviews of Geophysics and Space Physics 10 (4), 885-917.

Pedersen, M.W., Ruetr, A., Schweger, C., Friebe, H., Staff, R.A., Kjeldsen, K.K., Mendoza, M.L.Z., Beaudoin, A.B., Zutter, C., Larsen, N.K., Potter, B.A., Nielsen, R., Rainville, R.A., Orlando, L., Meltzer, D.J., Kjaer, K.H., Willerslev, E. 2016. Postglacial viability and colonization in North America's ice-free corridor. Nature 537, 45-49. http://doi. org/10.1038/nature19085.

Peltier, W.R. 1994. Ice age paleotopography. Science 265, 195-201. http://doi.org/10.1126/ science.265.5169.195.

Peltier, W.R. 2004. Global glacial isostasy and the surface of the ice-age earth: The ICE-5G (VM2) model and GRACE. Annual Reviews of Earth and Planetary Sciences 32, 111-149. http://doi. org/10.1146/annurev.earth.32.082503.144359.

Peltier, W.R., Argus, D.F., Drummond, R. 2015. Space geodesy constrains ice-age terminal deglaciation: the global ICE-6G_C (VM5a) model. Journal of Geophysical Research Solid Earth 120, 450-487. http://doi.org/10.1002/2014JB011176.

Piper, D.J.W., Skene, K.I. 1998. Latest Pleistocene ice-rafting events on the Scotian Margin (eastern Canada) and their relationship to Heinrich events. Palaeoceanography 13, 205-214. http://doi.org/10.1029/97PA03641.

Piper, D.J.W., Mudie, P.J., Fader, G.B., Josenhans, H.W., MacLean, B.,Vilks, G. 1990. Quaternary geology. In: M.J. Keen, G.L. Williams (Eds.), Geology of the Continental Margin of Eastern Canada. Geological Survey of Canada, Geology of Canada, No. 2, 475-607.

Prest, V.K. 1969. Retreat of Wisconsin and Recent ice in North America. Geological Survey of Canada Map, 1257A, scale 1:5000 000.

Prest, V.K. 1984. The Late Wisconsinan glacier complex. In: R.J. Fulton (Ed.), Quaternary Stratigraphy of Canada - a Canadian contribution to IGCP Project 24. Geological Survey of Canada, Paper 84-10, pp. 22-36.

Prest, V.K., Grant, D.R., Rampton, V.N. 1968. Glacial Map of Canada. Geological Survey of Canada Map, 1253A, scale 1:5000 000. 
Pritchard, H.D., Arthern, R.J., Vaughan, D.G., Edwards, L. 2009. Extensive dynamic thinning on the margins of the Greenland and Antarctic ice sheets. Nature 461, 971-975. http://doi. org/10.1038/nature08471.

Ramsay, W. 1931. Changes of sea level resulting from the increase and decrease of glaciations. Fennia 52, 1-62.

Rasmussen, S.O., Anderson, K.K., Svensson, A.M., Steffensen, J.P., Vinther, B.M., Clausen, H.B., Siggaard-Andersen, M.-L., Johnsen, S.J., Larsen, L.B., Dahl- Jensen, D., Bigler, M., Röthlisberger, R., Fischer, H., Goto-Azuma, K., Hansson, M.E., Ruth, U. 2006. A new Greenland ice core chronology for the last glacial termination. Journal of Geophysical Research 111, D06102. http://doi.org/10.1029/2005JD006079.

Ritz, C., Edwards, T.L., Durand, G., Payne, A.J., Peyaud, V., Hindmarsh, R.C.A. 2015. Potential sea-level rise from Antarctic ice-sheet instability constrained by observations. Nature 528, 115-118. http://doi.org/10.1038/nature16147.

Robel, A.A., Tziperman, E. 2016. The role of ice stream dynamics in deglaciation. Journal of Geophysical Research - Earth Surface 121, http://doi.org/10.1002/2016JF003937.

Ross, M., Campbell, J.E., Parent, M., Adams, R.S. 2009. Palaeo-ice streams and the subglacial landscape mosaic of the North American mid-continental prairies. Boreas 38 (3), 421-439. http://doi.org/10.1111/j.1502-3885.2009.00082.x.

Ross, M., Lajeunesse, P., Kosar, K.G.A. 2011. The subglacial record of northern Hudson Bay: insights into the Hudson Strait Ice Stream catchment. Boreas 40 (1), 73-91. http://doi. org/10.1111/j.1502-3885.2010.00176.x.

Ross, M., Utting, D.J., Lajeunesse, P., Kosar, K.G.A. 2012. Early Holocene deglaciation of northern Hudson Bay and Foxe Channel constrained by new radiocarbon ages and marine reservoir correction. Quaternary Research 78, 82-94. http://doi.org/10.1016/yqres.2012.03.001.

Schnikter, D., Belknap, D.F., Bacchus, T.S., Friez, J.K., Lusardi, B.A., Popek, D.M. 2001. Deglaciation of the Gulf of Maine. Geological Society of America Special Paper 351, 9-34.

Shapiro, B. , Drummond, A.J., Rambaut, A., Wilson, M.C., Matheus, P.E., Sher, A.V., Pybus, M.C., Gilbert, M.T.P., Barnes, I., Binladen, J., Willerslev, E., Hansen, A.J., Baryshnikov, G.F., Burns, J.A., Davydov, S., Driver, J.C., Froese, D.G., Harington, C.R., Keddie, G., Kosintsev, P., Kunz, M.L., Martin, L.D., Stephenson, R.O., Storer, J., Tedford, R., Zimov, S., Cooper, A. 2004. Rise and fall of the Beringian Steppe Bison. Science 306, 1561-1565. http://doi. org/10.1126/science. 1101074 .

Shaw, J. 2003. Submarine moraines in Newfoundland coastal waters: implications for deglaciation of Newfoundland and adjacent areas. Quaternary International 99-100, 115134. http://doi.org/10.1016/S1040-6182(02)00125-8.

Shaw, J., Piper, D.J.W., Fader, G.B.J., King, E.L., Todd, B.J., Bell, T., Batterson, M.J., Liverman, D.G.E. 2006. A conceptual model of the deglaciation of Atlantic Canada. Quaternary Science Reviews 25, 2059-2081. http://doi.org/10.1016/j.quascirev.2006.03.002.

Shaw, J., Todd, B.J., Brushett, D., Parrott, D.R., Bell, T. 2009. Late Wisconsinan glacial landsystems on Atlantic Canadian shelves: new evidence from multibeam and single-beam sonar data. Boreas 38 (1), 146-159. http://doi.org/10.1111/j.1502-3885.2008.00042.x.

Shepherd, A., Ivins, E.R., Barletta, A.G., Bentley, V.R., Bettadpur, M.J., Briggs, S., Bromwich, K.H., Forsberg, D.H., Galin, R., Horwath, N., Jacobs, M., Joughin, S., King, I., Lenaerts, M.A., Li, J.T., Ligtenberg, J., Luckman, S.R., Luthcke, A., McMillan, S.B., Meister, M., Milne, R., Mouginot, G., Muir, J., Nicolas, A., Paden, J.P., Payne, J., Pritchard, A.J., Rignot, H., Rott, E., Sorensen, H., Scambos, L.S., Scheuchl, T.A., Schrama, B., Smith, E.J., Sundal, B., van Angelen, A.V., van de Berg, J.H., van den Broeke, W.J., Vaughan, M.R., Velicogna, D.G., Wahr, I., Whitehouse, J., Wingham, P.L., Yi, D.J., Young, D., Zwally, H.J. 2012. A reconciled estimate of ice-sheet mass balance. Science 338 (6111), 1183-1189. http://doi.org/10.1126/science.1228102. 
Shilts, W.W. 1980. Flow patterns in the central North American ice sheet. Nature 286, 213-218. http://doi.org/10.1038/286213a0.

Shilts, W.W., Cunningham, C.M., Kaszycki, C.A. 1979. Keewatin Ice Sheet - re-evaluation of the traditional concept of the Laurentide Ice Sheet. Geology 537-541.

Simon, K., James, T.S., Forbes, D.L., Telka, A.M., Dyke, A.S., Henton, J.A. 2014. A relative sea-level history for Arviat, Nunavut, and implications for Laurentide ice sheet thickness west of Hudson Bay. Quaternary Research 82, 185-197. http://doi.org/10.1016/j. yqres.2014.04.002.

Smith, D.G., Fisher, T.G. 1993. Glacial Lake Agassiz: the northwestern outlet and palaeoflood. Geology 21, 9-12.

Stalker, A. 1977. The probable extent of classical Wisconsin ice in southern and central Alberta, Canadian Journal of Earth Sciences 14, 2614-2619.

Stea, R.R., Mott, R.J. 1998. Deglaciation of Nova Scotia: stratigraphy and chronology of lake sediment cores and buried organic sections. Géographie Physique et Quaternaire 52, 3-21.

St-Onge, D.A. 1987. The Sangamonian stage and the Laurentide Ice Sheet. Géographie Physique et Quaternaire 41 (2), 189-198.

Stokes, C.R., Clark, C.D. 1999. Geomorphological criteria for identifying Pleistocene ice streams. Annals of Glaciology 28 (1), 67-74. http://doi.org/10.3189/172756499781821625.

Stokes, C.R., Clark, C.D. 2001. Palaeo-ice streams. Quaternary Science Reviews 20, 1437-1457. http://doi.org/10.1016/S0277-3791(01)00003-8.

Stokes, C.R., Clark, C.D. 2003. The Dubawnt Lake palaeo-ice stream: evidence for dynamic ice sheet behaviour on the Canadian Shield and insights regarding the controls on ice-stream location and vigour. Boreas 32 (1), 263-279. http://doi.org/10.1080\&sol;03009480310001155.

Stokes, C.R., Clark, C.D. 2004. Evolution of late glacial ice-marginal lakes on the northwestern Canadian Shield and their influence on the location of the Dubawnt Lake palaeo-ice stream. Palaeogeography, Palaeoclimatology, Palaeoecology 215, 155-71. http://doi. org/10.1016/j.palaeo.2004.09.006.

Stokes, C.R., Tarasov, L. 2010. Ice streaming in the Laurentide Ice Sheet: a first comparison between data-calibrated numerical model output and geological evidence. Geophysical Research Letters 37, L01501. http://doi.org/10.1029/2009GL040990.

Stokes, C.R., Clark, C.D., Storrar, R. 2009. Major changes in ice stream dynamics during deglaciation of the north-western margin of the Laurentide Ice Sheet. Quaternary Science Reviews 28 (7-8), 721-738. http://doi.org/10.1016/j.quascirev.2008.07.019.

Stokes, C.R., Tarasov, L., Dyke, A.S. 2012. Dynamics of the North American Ice Sheet Complex during its inception and build-up to the Last Glacial Maximum. Quaternary Science Reviews 50, 86-104. http://doi.org/10.1016/j.quascirev.2012.07.009.

Stokes, C.R., Tarasov, L., Blomdin, R., Cronin, T., Fisher, T.G., Gyllencreutz, R., Hättestrand, C., Heyman, J., Hindmarsh, R.C.A., Hughes, A.L.C., Jakobsson, M., Kirchner, N., Livingstone, J.J., Margold, M., Murton, J.B., Noormets, R., Peltier, W.R., Peteet, D.M., Piper, D.J.W., Preusser, F., Renssen, H., Roberts, D.H., Roche, D.M., Saint-Ange, F., Stroeven, A.P., Teller, J.T. 2015. On the reconstruction of palaeo-ice sheets: recent advances and future challenges. Quaternary Science Reviews 125, 15-49. http://doi.org/10.1016/j.quascirev.2015.07.016.

Stokes, C.R., Margold, M., Clark, C.D., Tarasov, L. 2016. Ice stream activity scaled to ice sheet volume during Laurentide Ice Sheet deglaciation. Nature 530, 322-326. http://doi.org/10.1038/ nature 16947.

Storrar, R.D., Stokes, C.R., Evans, D.J.A. 2014. Increased channelization of subglacial drainage during deglaciation of the Laurentide Ice Sheet. Geology 42 (3), 239-242. http://doi. org/10.1130/G35092.1.

Stuiver, M., Reimer, P.J. and Reimer, R.W. 2017. CALIB 7.1 [WWW program] at http://calib.org, accessed 2017-2-1. 
Sugden, D.E. 1977. Reconstruction of the morphology, dynamics and thermal characteristics of the Laurentide Ice Sheet at its maximum. Arctic and Alpine Research 9 (1), 21-47.

Sugden, D.E., Watts, S. 1977. Tors, felsenmeer and glaciation in northern Cumberland Peninsula, Baffin Island. Canadian Journal of Earth Sciences 14, 2817-2823.

Svendsen, J., Alexanderson, H., Astakhov, V., Demidov, I., Julian, A., Funder, S., Gataulling, V., Henriksen, M., Hjort, C., Houmark-Nielsen, M., Hubberten, H., Ingulfsson, O., Jakobsson, M., Kjer, K., Larsen, E., Lokrantz, H., Lunkka, J., Lys, A., Mangerud, J., Matiouchkov, A., Murray, A., Muller, P., Niessen, F., Nikolskaya, O., Polyak, L., Saarnisto, M., Siegert, C., Siegert, M., Spielhagen, R., Ruedige, S. 2004. Late Quaternary ice sheet history of Northern Eurasia. Quaternary Science Reviews 23, 1229-1271. http://doi.org/10.1016/j.quascirev.2003.12.008.

Tanner, W.F. 1965. Cause and development of an Ice Age. The Journal of Geology 73, 413-429.

Tarasov, L., Peltier, W.R. 2005. Arctic freshwater forcing of the Younger Dryas cold reversal. Nature 435, 662-665. http://doi.org/10.1038/nature03617.

Tarasov, L., Dyke, A.S., Neal, R.M., Peltier, W.R. 2012. A data-calibrated distribution of deglacial chronologies for the North American ice complex from glaciological modelling. Earth and Planetary Science Letters 315-316, 30-40. http://doi.org/10.1016/j.eps1.2011.09.010.

Teller, J.T. 2013. Lake Agassiz during the Younger Dryas. Quaternary Research 80, 361-369. http://doi.org/10.1016/j.yqres.2013.06.011.

Teller, J.T., Thorleifson, L.H. 1983. The Lake Agassiz-Lake Superior connection. In: J.T. Teller, L. Clayton (Eds.), Glacial Lake Agassiz. Geological Association of Canada Special Paper, 26, 261-290.

Thorleifson, L.H., Wyatt, P.H., Warman, T.A. 1993. Quaternary stratigraphy of the Severn and Winisk drainage basins, northern Ontario. Geological Survey of Canada Bulletin 442, 59 pp.

Todd, B.J., Valentine, P.C., Longva, O., Shaw, J. 2007. Glacial landforms on German Bank, Scotian Shelf: evidence for Late Wisconsinan ice-sheet dynamics and implications for the formation of De Geer moraines. Boreas 36 (2), 148-169. http://doi.org/10.1111/j.1502-3885.2007.tb01189.x.

Tushingham, A.M., Peltier, W.R. 1991. ICE-3G: A new global model of late Pleistocene deglaciation based upon geophysical predictions of post-glacial relative sea level change: Journal of Geophysical Research 96, 4497-4523.

Tyrell, J.B. 1898. The glaciation of north-central Canada. Journal of Geology 6, 147-160.

Ullman, D.J., Carlson, A.E., LeGrande, A.N., Anslow, F.S., Moore, A.K., Caffee, M., Syverson, K.M., Licciardi, J.M. 2015a. Southern Laurentide ice-sheet retreat synchronous with rising boreal summer insolation. Geology 43 (1), 23-26. http://doi.org/10.1130/G36179.1.

Ullman, D.J., Carlson, A.E., Anslow, F.S., LeGrande, A.N., Licciardi, J.M. 2015b. Laurentide ice-sheet instability during the last deglaciation. Nature Geoscience 8, 534-537. http://doi. org/10.1038/ngeo2463.

Ullman, D.J., Carlson, A.E., Hostetler, S.W., Clark, P.U.,Cuzzone, J., Milne, G.A., Winsor, K., Caffee, M. 2016. Final Laurentide ice-sheet deglaciation and Holocene climate-sea level change. Quaternary Science Reviews 152, 49-59. http://doi.org/10.1016/j.quascirev.2016.09.014.

Van den Broeke, M., Bamber, J., Ettema, J., Rignot, E., Schrama, E., van de Berg, W.J., van Meijgaard, E., Velicogna, I., Wouters, B. 2009. Partitioning recent Greenland mass loss. Science 326, 984-986. http://doi.org/10.1126/science.1178176.

Veillette, J.J., Dyke, A.S., Roy, M. 1999. Ice-flow evolution of the Labrador Sector of the Laurentide Ice Sheet: a review, with new evidence from northern Quebec. Quaternary Science Reviews 18 (8-9), 993-1019. http://doi.org/10.1016/S0277-3791(98)00076-6.

Vettoretti, G., Peltier, W.R. 2013. Last Glacial Maximum ice sheet impacts on North Atlantic climate variability: the importance of a sea ice lid. Geophysical Research Letters 40, 63786383. http://doi.org/10.1002/2013GL058486.

Vincent, J.-S. 1982. The Quaternary history of Banks Island, NWT, Canada. Géographie Physique et Quaternaire 36, 209-232. 
Vincent, J.-S., Prest, V.K. 1987. The early Wisconsinan history of the Laurentide Ice Sheet. Géographie Physique et Quaternaire 41 (2), 199-213.

Wickert, A.D. 2016. Reconstruction of North American drainage basins and river discharge since the Last Glacial Maximum. Earth Surface Dynamics 4, 831-869. http://doi.org/10.5194/ esurf-4-831-2016.

Winsborrow, M.C.M., Clark, C.D., Stokes, C.R. 2004. Ice streams of the Laurentide Ice Sheet. Géographie Physique et Quaternaire 58 (2-3), 269-280.

Winsborrow, M.C.M., Clark, C.D., Stokes, C.R. 2010. What controls the location of ice streams? Earth-Science Reviews 103, 45-59. http://doi.org/10.1016/j.earscirev.2010.07.003.

Wright, H.E. 1973. Tunnel valleys, glacial surges, and subglacial hydrology of the Superior Lobe, Minnesota. In: R.F. Black, R.B. Goldthwait, H.B. Willman (Eds.), The Wisconsinan Stage. Geological Society of America Memoirs. Geological Society of America, pp. 251-276. 